Ohnmacht Magdolna

\title{
A progresszív aspektus mint temporális determináns-függvény
}

Témavezető: dr. Maleczki Márta

SZTE EIméleti Nyelvészet

Szeged, 2012 
Fauszt Máriának 


\section{Köszönetnyilvánítás'}

Avagy akik nélkül ez a dolgozat nem jöhetett volna létre

Mindenekelőtt szeretném megköszönni Marynek, Rékának, Olíviának, Amandának, Marinak, Tamásnak, Johnnak, Billnek, Samnek, Jánosnak, Aurélnak és Pedrónak (bár ő nem érdemli meg), hogy minden zokszó nélkül türték tolakodásomat. Betekintést engedtek magánéletükbe, még ha olyan bensőséges pillanatokban zavartam is őket, mint a sütés, a locsolás vagy a tévénézés. Fáradhatatlan segítőkészségükkel a kedvemért még Kínába is elutaztak, vagy napokig hánykolódtak a tengeren vitorlásukkal, sőt, még a haláltól sem riadtak vissza. Türelemmel viselték, hogy akármibe fogtak, minden tevékenységükben megakasztottam őket, és nem hagyłam, hogy befejezzék. Köszönöm.

Köszönöm a szüleimnek, hogy éveken keresztül olyan sokat segítettek, nem kímélve magukat, hogy idáig eljuthassak. Nélkülük diplomám sem lenne. Férjemnek köszönöm a technikai segítséget, és ami fontosabb: mindig maximálisan támogatott, hogy nyelvészettel foglalkozzak, sose mondta, hogy keressek már valami rendes munkát. És az egész rokonságnak köszönöm a szurkolást.

Köszönöm Alberti Gábornak, aki mindig bízott a képességeimben, és a pécsi egyetemen nyelvészeti tanulmányaim megalapozása során megismertetett a matematika számomra addig ismeretlen területeinek szépségeivel.

\footnotetext{
1 Jelen kutatási eredmények megjelenését „Az SZTE Kutatóegyetemi Kiválósági Központ tudásbázisának kiszélesítése és hosszú távú szakmai fenntarthatóságának megalapozása a kiváló tudományos utánpótlás biztosításával" címü, TÁMOP-4.2.2/B-10/1-2010-0012 azonosítószámú projekt támogatja. A projekt az Európai Unió támogatásával, az Európai Szociális Alap társfinanszírozásával valósul meg.
} 
Köszönöm Maleczki Mártának, aki megmutatta, hogy ezeknek a szépségeknek - az addig ismerteken kívül - még mi köze van a nyelvhez, és akitől megtanultam: a tudományban nincs megalkuvás.

Köszönöm Bujdosó Istvánnak a bátorságát és a tanácsait, és hogy az első tudományos írásművem megszületésénél bábáskodott, ami meghatározó volt a tanulmányaim folytatásában.

Köszönöm az SZTE Általános Nyelvészeti Tanszék tanárainak és dokłorandusztársaimnak a támogatását, biztatását és segítségét. Külön köszönöm Tóth Csillának a formaságokat, és hogy sokszor együtt ült velem a hullámvasútban.

Köszönöm az előopponenseknek, hogy alapos bírálatukkal megmutatták a mércét, amit el kell érnem. Nagyon sokat tanultam előopponensi véleményükből.

És köszönöm a témavezetőmnek, hogy magát sem kímélve kisajtolta belőlem ezt a dolgozatot! 


\section{Tartalom}

2. Szakirodalmi előzmények

2.1. Intenzionális modellek

2.1.1. Dowty 1979

2.1.2. Landman 1992

2.1.3. Varasdi 2006

2.2. Extenzionális modellek

2.2.1. Parsons 1989

2.2.2. Kearns 1991

3. A progresszív a magyarban 30

3.1 Kiefer aspektuális rendszere $\quad 30$

3.2. A progresszívot kifejező grammatikai eszközök 34

3.3. A vizsgált nyelvi anyag 39

3.3.1. A progresszív megszorításai: Az időmódosítók problémája 41

3.3.2. Az időmódosítók szintaktikai és szemantikai viselkedése 44

3.3.3. Az időpontot vagy szakaszt jelölő időhatározók szintaktikai és $\begin{array}{ll}\text { szemantikai viselkedése } & 47\end{array}$

3.3.4. Az időmódosítók problémája információs szerkezeti megközelítésben 53

4. A temporális topik jellemzői

4.1. Kiterjedés

4.2. Az unicitás $\quad 58$

4.3. Glasbey temporális topik intervalluma (TTI) 63

$\begin{array}{ll}\text { 4.4. A TTI topik státusza } & 67\end{array}$ 
5. A temporális determináns-függvények felé

5.1. Elméleti háttér: az általánosított kvantorok elmélete

5.1.1. Monotonitás

5.1.2 Általános determinánsi tulajdonságok

5.1.2.1. Kiterjeszthetőség

5.1.2.2. Konzervativitás

5.2. Szakirodalmi háttér

5.2.1. A progresszív mint határozott igeidő (Kearns 1991)

5.2.2. Az események mint időpontok tulajdonságai (R. Montague) 86

5.2.3. A temporális kifejezések mint megszámlálható főnevek (E. Corazza)

6. A temporális általánosított kvantorok

6.1. Mi felel meg a mondatban a temporális determinánsnak?

6.2. A temporális modell: Kamp - Schiehlen (2001)

6.3. Referenciailitás a temporális tartományban

6.3.1. Temporális anaforák (Partee 1984)

6.3.2. Az időre referálás eszközei: Blackburn (1994) 105

6.3.3. A mondatok feltételezett temporális szerkezete 107

6.4. Az általánosított kvantorok elmélete a temporális tartományban 111

$\begin{array}{ll}\text { 6.5.Az aspektusok determinánsi jellemzői } & 117\end{array}$

$\begin{array}{ll}\text { 6.5.1. Az aspektusok monotonitása } & 117\end{array}$

6.5.2. Az aspektusok és az általános determinánsi tulajdonságok:

a konzervativitás 
„....However said, it would happen all the same - as inevitably, as relentlessly, as inexorably as time always happens the seconds ticking away, the minutes mounting, the hours going in, the days passing, weeks flying by, months peeling away and the years rolling on." (John Cairney)

\section{Bevezetés}

A progresszív aspektus jelentésének informális megfogalmazását Otto Jespersen nevéhez kötik, aki a következőket mondja:

Épp vadászott. - A vadászat valaminek a kereteként jelenik meg; mint ami már korábban elkezdödött és talán (söt valószínüleg) még tartani fog ezt a másvalamit követöen is, amelyre ugyan nem történik utalás, de végig a beszélő szeme elött lebeg. ${ }^{2}$

Ezt az olvasatot nevezem temporális keret olvasatnak, amely alapján a progresszív esemény temporális keretet jelent a mondat kiértékelésének időpontjához (a referenciaidőhöz) képest. A Jespersen által megfogalmazottak formalizálására tett kísérletekkel kapcsolatban azonban a kezdetektől merülnek fel problémák. Bennett Partee (1978) definíciója a következő:

\footnotetext{
${ }^{2}$ He was hunting. - ,The hunting is felt to be a kind of frame round something else; it is represented as lasting sometime before and possibly (or probably) also some time after something else, which may or may not be expressly indicated, but which is always in the mind of the speaker." (1932: 178-80. oldal) Az idézetet Kearnstöl vettem át (Kearns 1991, 33. oldal).
} 
(1) [PROG $]$ akkor és csak akkor igaz t intervallumnál, ha létezik olyan I intervallum, amelyre teljesül, hogy $t$ valódi részhalmaza I-nek, $t$ nem záró intervalluma I-nek, és $\alpha$ igaz I-nél. ${ }^{3}$

A fenti definíció kapcsán felmerülő két fő probléma az imperfektív paradoxon és a megszakítás problémája. Az imperfektív paradoxon a telikus predikátumok esetében felmerülő jelenség, amit a következő példák szemléltetnek (Dowty (1979) példái, 133. oldal, (1-4):

\section{John was drawing a circle. \\ John rajzol-MÚLT PROG egy kör \\ 'John éppen rajzolt egy kört.'}

\section{John drew a circle.}

John rajzol-MúLT egy kör

'John rajzolt egy kört.'

\section{John was pushing a cart.}

John tol- MÚLT PROG egy taliga

'John éppen taligát tolt.'

\section{John pushed a cart.}

John tol-MúLT egy taliga

'John eltolt egy taligát.'

Az imperfektív paradoxon abban áll, hogy a telikus predikátumok esetében a múlt idejü progresszív mondat igazságából nem mindig következik az egyszerü múlt idejű mondat igazsága, holott az atelikus predikátumok esetében mindig következik. Tehát (3)

${ }^{3},[\mathrm{PROG} \alpha]$ is true at $\mathrm{t}$ iff there is an interval $\mathrm{I}$ such that $\mathrm{t}$ is a proper subset of $\mathrm{I}, \mathrm{t}$ is not a final subinterval of I, and $\alpha$ is true at I." (Az idézetet Kearnstől vettem át: Kearns (1991), 35. oldal, ő Bennett-Partee (1978)-ként hivatkozik rá.) 
igazságából következik (4) igazsága is, ugyanakkor (1) igazsága nem feltétlenül teszi igazzá (2)-t, mivel a progresszív aspektusú állítást a telikus pont esetleges elérése előtt interpretálhatjuk.

Ettől megkülönböztetendő az a jelenség, amely az atelikus predikátumok esetében is problémát okoz, és amire a megszakítás problémájaként hivatkozom.

\section{5. Épp zongoráztam, amikor rám jött a köhögés.}

A progresszív aspektus (1)-ben adott definíciója a progresszív kiértékelési idejének megfeleltetett $t$ intervallumon túl feltételez egy azt magába foglaló $I$ intervallumot, amellyel az esemény folytatására hivatkozik. Az esemény megszakítása esetén azonban nincs a definíciónak megfelelő $I$ intervallum, hiszen az esemény nem folytatódik, a progresszív mondat mégis igaz lehet (lásd (5)). Az esemény megszakítása esetén természetesen az imperfektív paradoxon is megjelenik, ha telikus a predikátum, de azt nem maga a megszakítás okozza, hanem az, hogy a progresszív kiértékelési ideje megelőzheti a telikus pontot, még ha az esemény egyébként folytatódik is (lásd (6)).

6. Mari épp ment föl a lépcsőn, amikor megérkeztem, de nem vett tudomást rólam, amíg föl nem ért.

7. Mari épp ment föl a lépcsőn, amikor megérkeztem, úgyhogy megfordult, és elém sietett

A fenti progresszív tagmondatokban leírt telikus esemény a folytatás által nyújtott kontextusban (6) esetén befejeződik. Mégis, önmagában abból a progresszív eseményből, hogy ment föl a lépcsőn Mari, nem következik, hogy valóban föl is ment, hiszen a mondat úgy is folytatódhat, hogy kiderül: az esemény megszakadt (lásd (7)).

A létrehozást kifejező igéknél (verbs of creation) a folyamatban lévő esemény megszakításával jár együtt az is, hogy nem jön létre az esemény végterméke. Ilyen ige szerepel az (1) mondatban is, ahol az esemény megszakadásával lehetséges, hogy nem jön létre semmilyen kör, mégis akként referálunk rá. Ez a jelenség sem csak a telikus 
eseményeket leíró predikátumokat érinti. Bár az angolban az (1-2)-beli esemény telikus, ugyanez a jelenség a magyarban atelikus eseményeket leíró predikátumoknál is megfigyelhető (lásd (8)):

\section{Kenyeret sütöttem (..., de csak valami ragacs lett belöle)}

Erre a problémára adott újszerủ megoldást Terence Parsons (lásd Parsons (1989)) azzal, hogy az aktuális világban befejezetlen tárgyakat feltételezett, mint a folyamatban lévő létrehozást kifejező igék megszakításának valós végtermékeit. Mivel Parsons megoldásában nem feltételez lehetséges világokat, a ki nem teljesedett események következményeként megjelennek a befejezetlen objektumok. Ezeknek a feltételezését az egyébként lehetséges világokat alkalmazó Landman (1992) sem utasítja el, hiszen valóban léteznek ilyen objektumok (lásd részletesebben a 2.2.1. szakaszban).

A dolgozatban csak a megszakítás problémájával foglalkozom, tehát azzal, hogy egy progresszív aspektusú mondat igaz lehet, függetlenül attól, hogy az általa leírt, folyamatban lévő esemény kiteljesedik-e vagy megszakad. A megszakítás problémája azért jelenik meg a progresszív aspektus fenti - és más hasonló (például Dowty (1979), Landman (1992)) - definíciója esetében, mert a Jespersen által megfogalmazott temporális keretet próbálják megragadni. A dolgozatban bemutatott kutatás eredménye ahhoz a Parsons által is képviselt állásponthoz nyújt érvet, amely szerint egy progresszív állítás igazságának szempontjából csak a kiértékelés ideje számít, a temporális keret nem. Az általánosított kvantorok elméletének segítségével olyan elemzését adom a vizsgált progresszív mondatoknak, amelynek alapján ez az állítás levezethetővé válik más, függetlenül indokolható alapfeltevésekböl.

A dolgozat felépítése a következő: a második fejezetben áttekintem a progresszív aspektussal foglalkozó bőséges nemzetközi szakirodalmi előzmények közül azokat, amelyek relevánsak a dolgozatban kifejtett alapfeltevések szempontjából, a teljesség igénye nélkül. A bemutatott elméletek közt mind intenzionális, mind extenzionális elméletek szerepelnek. 
A harmadik fejezetben egyrészt a magyar aspektológiai szakirodalomból ismertetek néhány elméletet, másrészt a magyar nyelvi adatokat elemzem. A progresszív aspektusú mondatok meglehetősen kötöttek szemantikailag és szintaktikailag egyaránt, például megszorítást jelentenek a bennük megjelenő időhatározókra. A dolgozatban olyan mondatokat vizsgálok, amelyekben a progresszív eseményt kifejező tagmondat fömondati pozícióban van, és megjelenik benne valamilyen időhatározó, ami a referenciaidőt jelöli.

\section{Hol voltál/Mit csináltál, amikor fellötték a Challanger ürhajót?}

10. Épp túráztam (, amikor fellötték a Challanger ürhajót) ..., úgyhogy csak a másnapi hírekböl hallottam a tragédiáról.

Az időhatározók vizsgálata alapján a progresszív mondatokat olyan kategorikus ítéleteknek tekintem, amelyek az időhatározó által jelölt referenciaidőről mint diskurzus topikról tesznek állítást, amit ezért temporális topiknak nevezek.

A negyedik fejezetben a temporális topik tulajdonságait vizsgálom, valamint az angol present perfect esetében a Glasbey (2005) által temporális topiknak tekintett időhatározóról megmutatom, hogy valójában nem topik szerepü.

Végül az ötödik fejezetben a dolgozatban használt elméleti keret bemutatása után olyan tanulmányokat ismertetek, amelyek alátámasztják a vizsgálat alapját képező feltevést, mely szerint a progresszív mondatban álló időhatározó az individuumokhoz hasonlóan kezelhető általánosított kvantorként. Az elmélet alkalmazásának eredményeképp megállapítom, hogy az aspektus a temporális tartományban ugyanazt a szerepet tölti be, mint a fónévi tartományban a determinánsok, ezen belül a progresszív aspektus határozott determináns. A progresszív aspektus ebben a megközelítésben tehát egy temporális determináns, vagyis egy olyan függvény, amely a temporális univerzum egy intervallumához (a temporális topik denotációjához) a temporális univerzum részhalmazainak egy halmazát rendeli hozzá, ahogy a fönévi determinánsok az individuumokhoz (a fönévi/individuum topik denotációjához individuumok halmazának egy halmazát rendelik. A temporális topik jelöletét tehát időintervallum helyett 
időintervallum-halmazok halmazának tekintjük, ahogy a főnévi tartományban az individuumokat is individuumhalmazok halmazaként kezeljük. Az adott elméleti keretben is alkalmazható általános determinánsi tulajdonságokból - pontosabban a konzervativitásból - az fog következni, hogy a progresszív aspektusú állítások igazságértéke szempontjából a referenciaidőt követő időintervallum és annak történései irrelevánsak. 


\section{Szakirodalmi előzmények}

A progresszív hivatkozott definíciója kapcsán a bevezetőben bemutatott problémákra sokféle megoldási kísérlet született (és születik ma is), amelyeket alapvetően két csoportba lehet sorolni. Az egyikbe azok tartoznak, amelyek extenzionális keretben kívánják megoldani ezeket a problémákat, a másikba azok, amelyek intenzionális keretben. Az alábbiakban mindkét csoportból ismertetek néhányat, a megszakítás problémáját helyezve a középpontba.

\subsection{Intenzionális modellek}

A progresszív aspektus szemantikáját a bevezetőben mondottak alapján úgy kell megadni ahhoz, hogy ne merüljön föl a megszakítás problémája, hogy nem szerepelhet benne a tényleges folytatódás feltétele. Az intenzionális elméletek ezt lehetséges világok segítségével kívánják megoldani úgy, hogy az esemény megszakadása esetén annak kiteljesedését az aktuális világból elérhető bizonyos lehetséges világokban feltételezik, az aktuális világban nem. Ezek közül ismertetek az alábbiakban hármat.

\subsubsection{Dowty (1979): Inerciavilágok}

A progresszív aspektus szemantikájának megadásában az intenzionalitás bevonásának szükségessége David Dowty nevéhez füződik. Dowty (1979) megállapítja, hogy a bevezetésben ismertetett Bennett - Partee féle intervallumszemantikai definíció alapján az (1)-es mondat igazságából (John was drawing a circle) - helytelenül - következne a (2)-es mondat igazsága (John drew a circle). Szerinte az (1)-es mondatból csupán arra kellene tudnunk következtetni, hogy John cselekvésének csak egy lehetséges kimenetele 
egy kör létezése. Ez a megfigyelés azt sugallja, hogy a progresszív nem egy egyszerü temporális operátor, hanem egyfajta modális-temporális operátor. ${ }^{4}$ Dowty szerint ennek megfelelően egy progresszív mondat igazságát egy $I$ intervallumhoz és egy $w$ lehetséges világhoz képest kell megállapítani (Dowty (1979), 146. o.):

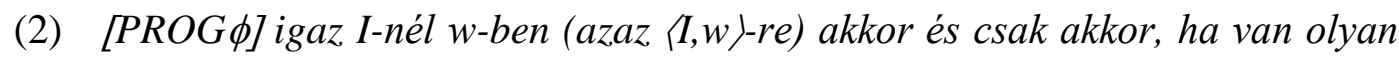
I' intervallum, amelyre I $\subset$ I', és I nem záró részintervalluma I'-nek, továbbá van olyan w', amelyre teljesül, hogy $\phi$ igaz I'-nél w'-ben ( $\left.\left(I^{\prime}, w^{\prime}\right\rangle-r e\right)$, és w pontosan olyan, mint w' minden I-t megelözö és tartalmazó intervallumnál. ${ }^{5}$

E definíció alapján azonban az alábbi mondatokat tévesen igaznak kellene ítélnünk egy olyan szituációban, amelyben feldobtunk egy érmét, és az még nem esett le:

11. \#The coin is coming up heads.

Az érme jön-JELEN PROG fel fej-TSZ

'Éppen fej lesz.'

12. \#The coin is coming up tails. ${ }^{6}$

Az érme jön-JELEN PROG fel hátsó-TSZ

'Éppen írás lesz.'

Mivel az aktuális világból elérhető lehetséges világok között vannak olyanok is, amelyekben az érme a fej oldalára esik, és vannak olyanok is, amelyekben az írás oldalára, ezért mindkét mondat esetében találunk az aktuális világból elérhető olyan

\footnotetext{
${ }^{4}$ Dowty (1979), 146. o.: „As I pointed out earlier, however, one should be able to conclude from (1) no more than that the existence of a circle was (or will be) a possible outcome of John's activity. This observation suggests that the progressive is not simply a temporal operator, but a kind of mixed modaltemporal operator."

${ }^{5}$ O.M. fordítása, az eredeti szöveg: ,[PROG $\left.\phi\right]$ is true at $\langle\mathrm{I}, \mathrm{w}\rangle$ iff there is an interval I' such that Ic I' and $\mathrm{I}$ is not a final subinterval for I' and there is a world $\mathrm{w}^{\prime}$ for which $\phi$ is true at $\left\langle\mathrm{I}^{\prime}, \mathrm{w}^{\prime}\right\rangle$, and $\mathrm{w}$ is exactly like w' at all times preceeding and including I." (Dowty (1979), 146. o.)

${ }^{6} \mathrm{Az}$ eredeti problémát Thomason vetette föl; a jelenség a ma Bonomi nevével fémjelzett multiple-choice paradoxon, ami abban áll, hogy pénzfeldobás esetén akár fej lesz, akár írás, a (11-12)-beli progresszív mondatok egyikére sem mondható, hogy igaz.
} 
lehetséges világot, amelyben a mondat által leírt esemény kiteljesedik, vagyis mindkét mondat igaz lenne. Mivel azonban egyik mondatot sem tartja az intuíciónk igaznak, Dowty szerint két ponton szükséges a definíció módosítása, a következőképpen (Dowty (1979), 149. о.):

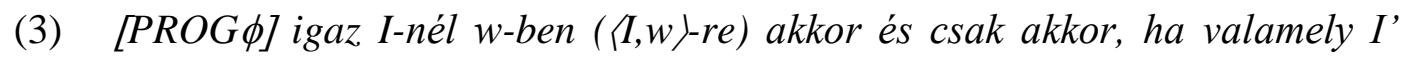
intervallumra, amely olyan, hogy I $\subset$ I'és I nem záró részintervalluma I'nek, továbbá minden olyan w'-re, amely olyan, hogy w' $\in \operatorname{Inr}(\langle I, w\rangle)$, teljesül, hogy $\phi \operatorname{igaz}\left\{I^{\prime}, w^{\prime}\right\rangle-$-re $)^{7}$

Az egyik módosítás az, hogy ez a definíció nem csak azt kívánja meg, hogy létezzen olyan lehetséges világ, amelyben az esemény folytatódik, hanem azt is, hogy mindegyik lehetséges világ olyan legyen. Mivel azonban a lehetséges világok között vannak, amelyekben az eredmény fej lett, és vannak, amelyekben írás, sem a (11), sem a (12) nem lehet igaz, hiszen ahhoz az összes világban neki megfelelő kifejlete kellene legyen az eseménynek. Így tehát az intuíciónknak megfelelően alakulnak a (11)-es és (12)-es állítások igazságfeltételei.

A másik módosítás az, hogy a szóban forgó világok inerciavilágok (w’e $\operatorname{Inr}(\langle\mathrm{I}, \mathrm{w}\rangle))$. Az inerciavilágok halmaza a lehetséges világoknak egy olyan részhalmaza, amely elemeinek a jellegzetessége, hogy bennük a valós esemény megszakításának időpillanatától a megszakítás helyett is minden a 'rendes, normális módján' folyik, nincsenek szokatlan, váratlan események, így a folyamatban lévő esemény kiteljesedhet az inerciavilágokban annak ellenére is, hogy az aktuális világban esetleg megszakad. ${ }^{8}$ Vagyis az eseménynek a progresszív állítás igazságához szükséges folytatása biztosított, és a megszakítás is lehetséges. (1) tehát igaz lehet a következő folytatással:

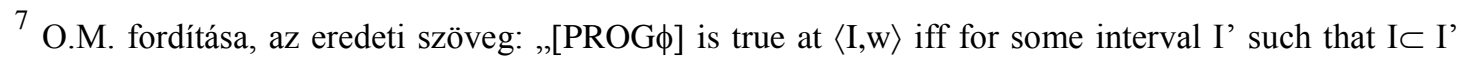
and I is not a final subinterval for I', and for all w' such that $\mathrm{w}^{\prime} \in \operatorname{Inr}(\langle\mathrm{I}, \mathrm{w}\rangle), \phi$ is true at $\left\langle\mathrm{I}^{\prime}, \mathrm{w}^{\prime}\right\rangle$."

${ }^{8}$ Dowty ugyanakkor aggályait is kifejezi az inerciavilágok bevezetésével kapcsolatban, amikor így fogalmaz: ,...Thus I reluctantly conclude that we must add to the definition of a model a new primitive function which assign to each index, consisting of a world and an interval of time, a set of worlds which might be called inertia worlds...”. Az inerciavilágok által képviselt normalitás fogalma valóban problémát jelent, és meghatározni sem egyszerü, ha ugyan nem lehetetlen. (Erről lásd a 2.1.2. szakaszt.)
} 
1. John was drawing a circle, when he changed his mind and tore the paper up. ${ }^{9}$

'John épp kört rajzolt...amikor meggondolta magát, és összetépte a papírt.'

Dowty hangsúlyozza ugyanakkor, hogy a megszakítás problémája nemcsak a teljesítménypredikátumokat érinti, a progresszív modális alapú megoldását a nem telikus események kezelése is indokolja (Dowty (1979) példái, 150. o.(27-28)).

13. John was watching television when Bill entered the room.

John néz-MÚLT PROG tévé amikor Bill belép-MÚLT a szoba

'John épp tévét nézett, amikor Bill belépett a szobába.'

\section{John was watching television when he fell asleep.}

John néz-MÚLT PROG tévé amikor ő esik-MÚLT álomban

'John épp tévét nézett, amikor elaludt.'

Dowty megállapítja, hogy (13)-ban ugyan Bill belépése után feltehetőleg pár pillanatig még nézheti John a tévét, mielőtt elveszi róla a tekintetét, tehát az esemény ez esetben az aktuális világban is folytatódik, de ez csupán egy következtetés, amit a társalgási ismereteink alapján végzünk el. Hogy ez így van, arra Dowty a (14)-es példát hozza. Ebben az esetben egyértelmü, hogy az esemény minimális mértékben sem folytatódik a megszakítást követően. Dowty szerint tehát a progresszív szemantikájának nem része, hogy az aktuális világban folytatódik az esemény, viszont a lehetséges kimenetelét az aktuális világban történtek alapján határozhatjuk meg, ezért következtetünk a (14)-es mondatból arra, hogy: „ha akkor John nem aludt volna el, folytatta volna a tévénézést még legalább pár pillanatig” (Dowty (1979), 150. oldal).

Dowty egy helyen külön kiemeli (lásd Dowty (1979), 149. o.), hogy a progresszív mondat igazsága szempontjából nem az számít, hogy az éppen folyamatban lévő eseménynek mi a valószínüsíthető kimenetele, hanem az, hogy mi van éppen

\footnotetext{
${ }^{9}$ A folytatás O.M. kiegészítése.
} 
folyamatban. ${ }^{10}$ Megoldása mégis az esemény folytatására épít: a progresszívet - a telikus és atelikus predikátumokat egységesen kezelve - két esemény közti relációnak tartja: egy folyamatban lévő aktuális, és egy kiteljesedett lehetséges esemény között.

\subsubsection{Landman 1992: Lehetséges folytatási ágak (continuation branches)}

A másik meghatározó intenzionális elmélet Fred Landmané. Landman (1992) egyértelmüen amellett foglal állást, hogy a progresszív intenzionális kontextust hoz létre, amit a következő példákkal támaszt alá (Landman (1992), 9. oldal, (7) és (10)):
15. Mary tried
to find a unicorn.
Mary próbál-MÚLT talál-INF egy egyszarvú
'Mary próbált találni egy egyszarvút.'

a) No wasicorn found.

sehány egyszarvú talál van-MÚLT-E/3 talál-V3

'Egyet sem talált.

b) She would sell it to Sue.

Ö AUX-FELT elad PRO-E/3 ELÖLJ-nak Sue

'Eladta volna Sue-nak.'

c) ? It was not found.

\footnotetext{
10 (26) Jones is ruining his academic reputation by publishing all those crackpot papers on politeness rules in Pre-Indo-European.

„,... what is at issue is what is happening now, what is the outcome of events as they could be expected to transpire without such interference."
} 
PRO-E/3 van-MÚLT-E/3 NEG talál-V3

'Nem találta meg.'

16. God was creating a unicorn.

Isten alkot-MÚLT PROG egy egyszarvú

'Isten éppen egyszarvút alkotott.

a) No unicorn was created.

sehány egyszarvú van-MÚLT-E/3 alkot-V3

'Egyet sem alkotott meg.'

b) He would give it to Eve.

Ö AUX-FELT ad PRO-E/3 ELÖLJ-nek Eve

'Odaadta volna Évának.'

c) ?It was not created.

PRO-E/3 van-MÚLT-E/3 NEG talál-V3

'Nem alkotta meg.'

A (15)-ös példamondatban a try 'próbál' ige intenzionális, míg a (16)-os nem intenzionális progresszív aspektusú predikátumot tartalmaz. Azt látjuk, hogy (15) és (16) esetében azonos anaforikus lehetőségeket mutatnak az egyes alpontok. Az (a) mindkét esetben tökéletes folytatás. A (15b) - ahol modális alárendelés van, és azon belül kell antecedenst találnia a névmásnak - szintén jó, ugyanígy (16b) is. A (c) viszont - valós egyszarvú hiányában - egyik esetben sem megfelelő folytatás, mivel nincs a névmás számára megfelelő antecedens. Mivel a create 'alkot' ige nem intenzionális, Landman szerint a példák azt mutatják, hogy a progresszívnek köszönhető az intenzionális kontextus létrejötte. Landman tehát alapvetően elfogadja Dowty megoldását, de megnevez néhány problémát, ami miatt az módosításra szorul. Az inerciavilágok bevezetésével megjelenik a normalitás fogalma, mert az 
inerciavilágokban minden a maga normális menetében halad. Ez viszont az alábbi példák esetében - más-más okból - problémába ütközik (Landman (1992), 10. oldal (13) és 14. oldal (17)).

17. Mary was crossing the street, when the truck hit her. Mary átkel-MÚLT PRROG az utca amikor a teherautó elüt-MÚLT őt 'Mary épp ment át az úton, amikor elütötte a teherautó.'

18. Mary was crossing the Atlantic.

Mary átszel-MÚLT PROG az Atlanti-óceán

'Mary épp úszott át az Atlanti-óceánon.'

Az egyik probléma, hogy ha (17) esetében minden a maga várható, normális menetében halad, akkor ez a teherautóra is igaz, és véve a balesetet megelőző pillanatokat, épp az lenne váratlan és meglepetésszerü, ha nem történne meg a találkozás, vagyis az inerciavilágokban is meg kell szakadjon Mary úton való átkelése. ${ }^{11}$ Landman szerint erre megoldás, ha intervallumok helyett eseményekre építjük a progresszív szemantikáját. Eszerint csak azon dolgok normális menete számít, amelyek az eseményhez (ez esetben Mary úton való átkelése) tartoznak, amelyben viszont így a teherautó nem szerepel.

A (18)-as esetében alapvetően egyértelmü, hogy a mondat nem lehet igaz, mert képtelenségnek tünik. A normalitásból eredő másik probléma, hogy ez azt jelenti, hogy az inerciavilágokban Mary mindig elmerül, hiszen ez a várható. Vannak azonban olyan esetek, amikor valami csoda folytán mégis sikerülnek olyan dolgok, amelyek nem mindennapiak. A mi esetünkben például, ha Marynek valóban sikerül átúsznia az Atlanti-óceánt, a mondat kétségtelenül igaz, Dowty megoldása alapján azonban nem lehetne az. Olyan modellt kell tehát adni, amely alapján (17) első tagmondata igaz lehet, akár megszakad az esemény, akár nem, (18) viszont csak akkor lehet igaz, ha az esemény az aktuális világban kiteljesedett.

\footnotetext{
${ }^{11}$ Vlach (1981) észrevétele.
} 
Landman (1992) megoldásában az egyik kulcsfogalom az elméletben a stage of reláció. Landman különbséget tesz a part of és a stage of reláció között. Ahhoz, hogy egy e esemény egy része (part of) az e eseménynek állomása (stage of) legyen, elég nagynak kell lennie, és elég jellemzőnek (mint tipikus része) kell lennie az e eseményre (Landman (1992), 23. oldal). ${ }^{12}$ A palacsintasütésnek például része (part of) az is, hogy lisztet öntök a tálba, és az is, hogy fölkötöm a hajamat, hogy ne hulljon bele a tésztába, de állomása (stage of) csak az elöbbi lehet.

A másik kulcsfogalom az ésszerü lehetőség (reasonable chance) fogalma, ami abban tér el a normalitástól, hogy kizárólag az eseményen belüli tényezőkön múlik, külső, pillanatnyi körülmények nem befolyásolják. A mi esetünkben ez Mary képessége/kapacitása, ezzel ragadható meg (17) és (18) különbsége. Amennyiben az esemény megszakad az aktuális világban, akkor a legközelebbi olyan világba lépünk át, amelyre ésszerű lehetőség van az aktuális világban, és az esemény folytatódik. Egy esemény akkor szakad meg egy világban, ha nincs olyan nagyobb esemény az adott világban, amelynek ez az állomása. Az ilyen világok láncolata a continuation branch. A legközelebbi világon azt a világot értjük, amelyikben az az egyetlen tényező nincs jelen, amely az aktuális megszakítást okozta. Így az esemény folytatódik mindaddig, amíg vagy kiteljesedik, vagy egy újabb tényező meg nem szakítja. Ez utóbbi esetben megint azt az eljárást követjük, amit az első megszakítás esetén. Ennek az eredménye vagy az lesz, hogy ésszerü mennyiségü lehetséges világon keresztül eljutunk egy olyanba, amelyikben kiteljesedik az esemény, vagy az, hogy egy idő után már nem minősül ésszerünek az esemény folytatása. Előbbi esetben igaz lesz a progresszív mondat, utóbbiban nem.

A (18)-as példa esetében Landman (1992) megoldásával tehát különbséget tudunk tenni aszerint is, hogy Mary átért-e a túlpartra. A mondat normális körülmények között nem lehet igaz, mert Mary képességei átlagos emberi mércével mérve nem engedik meg, hogy feltételezzük róla ezt a teljesítményt, vagyis n számú megszakítás elhárítása után még mindig kicsik lennének az esélyei, így egy idő után már nem lesz

$12, \ldots$ to be a stage, a part has to be big enough and share enough with e so that we can call it a less developed version of e." 
ésszerü a folytatás. Ha azonban valami csoda folytán Mary átér a túlpartra, akkor nem is kell a lehetséges világokhoz nyúlni, hiszen az aktuális világban kiteljesedik az esemény, tehát a mondat igaz lesz.

\subsubsection{Varasdi (2006): Feltételstruktúrák}

Varasdi (2006) az előzőekhez képest egészen más módon közelíti meg a progresszív szemantikáját: propozíciók segítségével. Az imperfektív paradoxont eredményező következtetési irány (progresszív $\rightarrow$ perfektív) helyett Varasdi (2006) Landman (1992)-re és Gendler-Szabó (2004)-re hivatkozva az ellenkező irányú következtetéseket veszi alapul (Landman (1992), 14. oldal).

19. Mary was writing a book. $* \rightarrow$ Mary wrote a book. Mary ír-MÚLT PROG egy könyv Mary ír-MÚLT egy könyv 'Mary könyvet írt.' * $\rightarrow$ 'Mary írt egy könyvet'

20. Mary wrote $\quad$ a book. $\rightarrow$ Mary was writing a book.

Mary ír-MÚLT egy könyv Mary ír-MÚLT PROG egy könyv

'Mary írt egy könyvet' $\rightarrow$ 'Mary könyvet írt.'

A (19)-ben láthahtó következtetés nem áll fenn, a (20)-ban látható azonban igen, mert ha Mary írt egy könyvet, akkor kellett lennie azt megelőzően olyan időpontnak vagy intenrvallumnak, amelyre igaz, hogy Mary könyvet ír. Egy kiteljesedett eseménynek tehát elengedhetetlen feltétele (sine qua non precondition) egy azt megelőző progresszív esemény. De például Mary létezése is elengedhetetlen feltétele a kiteljesedett (Mary wrote a book. 'Mary írt egy könyvet.') eseménynek, sőt nem csak a kiteljesedettnek, hanem a progresszívnek is (lásd Mary was writing a book. 'Mary könyvet írt.'), tehát ezek a feltételek nem egyenlő rangúak. Varasdi (2006) szerint a feltételeknek megadható az információtartalmuk szerinti következményreláció segítségével egy részbenrendezése 
$(\langle$ Antec, $\Rightarrow\rangle$ ), amelynek egy függvény (lásd $\mathcal{T}$ ) segítségével megfeleltethető egy a következmények halmazán értelmezett részbenrendezés (〈Conseq, $\leq\rangle)$. A következmények rendezett halmazán megadja a föszürök (介Conseq) halmazát, amely szintén rendezett ( $\subseteq$ reláció által), és ennek segítségével definiálja a progresszív propozicionális operátort a következöképp:

$$
\langle\mathrm{w}, \mathrm{t}\rangle\left|=\operatorname{Prog}(\alpha) \Leftrightarrow^{\mathrm{def}}\langle\mathrm{w}, \mathrm{t}\rangle\right|=\uparrow \tau(\alpha)
$$

Külön definiál egy Prog* propozicionális operátort, ami abban tér el Prog-tól, hogy akkor és csak akkor igaz egy $\alpha$ propozícióra, ha amellett, hogy $\alpha$ folyamatban van, $\uparrow \tau$ ( $\alpha$ ) maximális abban az értelemben, hogy nem terjeszthető ki egy olyan nagyobb föszürőre, amelyet $\langle\mathrm{w}, \mathrm{t}\rangle$ alátámaszt. ${ }^{13}$ Ahhoz, hogy egy előzetes feltevés igazzá tegyen egy progresszív mondatot, egyrészt olyan kell legyen, ami nem folytatódhat az esemény kiteljesedése után, másrészt a rendezésben a „legmagasabban” kell legyen, tehát a legspecifikusabbnak kell lennie. A (21)-es mondat szükséges feltételei láthatók (22-25)ben (Varasdi (2006) példája, 38. oldal, (34)). Intuitív alapon (25)-öt választjuk, mint ami igazzá teszi (21)-et, és a felsorolt szükséges feltételek közül ez a legspecifikusabb (a konkrét levezetést lásd később).

21. John is walking to the bank.

John megy-JELEN PROG ELÖLJ-ba a bank

'John épp megy a bankba.'

22. John létezése

23. John szándéka az, hogy a bankba menjen.

24. John lépked.

25. John lépked a bank felé.

\footnotetext{
${ }^{13}$ O.M. fordítása, az eredeti szöveg: , Prog* is true of $\alpha$ iff $\alpha$ is in progress and $\uparrow \mathcal{T}(\alpha)$ is maximal in the sense that it cannot be extended into a strictly bigger principal filter in $\Uparrow$ Conseq that is satisfied at $\langle\mathrm{w}, \mathrm{t}\rangle$." Varasdi (2006), 43.oldal.
} 
Varasdi (2006) megoldásának másik alapja a következő logikai azonosság, amellyel az azonos utótagú kondicionálisok előtagjai kapcsolhatók össze:

$$
\left(\mathrm{p}_{1} \rightarrow \mathrm{q}\right) \wedge\left(\mathrm{p}_{2} \rightarrow \mathrm{q}\right) \Leftrightarrow\left(\mathrm{p}_{1} \vee \mathrm{p}_{2}\right) \rightarrow \mathrm{q}
$$

A (21)-es mondatot tekintve egy olyan szituációban, amelyben a bankhoz és a postához ugyanabba az irányba kell menni, a következőket mondhatjuk (Varasdi (2006), 46. oldal):

$$
\begin{aligned}
& \alpha \equiv{ }^{\text {def }} \text { walkTo(john,bank) } \\
& \beta \equiv{ }^{\text {def }} \text { walkTo(john,post) } \\
& \mathrm{q}_{1} \equiv{ }^{\text {def }} \text { intend(walkTo(john,bank)) } \\
& \mathrm{q}_{2} \equiv{ }^{\text {def }} \text { intend(walkTo(john,post)) } \\
& \mathrm{q}_{3} \equiv{ }^{\text {def }} \text { walkToward(john,bank) } \\
& \mathrm{q}_{4} \equiv{ }^{\text {def }} \text { walkToward(john,post) }
\end{aligned}
$$

A bevezetett relációk és leképező függvény eredményeképp a következőket állapíthatjuk meg az említett szituációban (vagyis amikor a bank és a posta egy irányban van John tartózkodási helyéről nézve):
a) $\alpha \vee \beta \Rightarrow \alpha$, és $\alpha \vee \beta \Rightarrow \beta$,
b) $\mathcal{T}(\alpha \vee \beta)=\left\{\mathrm{q}_{3}, \mathrm{q}_{4}\right\} \quad$ és $\quad \mathcal{T}(\alpha)=\left\{\mathrm{q}_{3}\right\} \quad$ és $\quad \mathcal{T}(\beta)=\left\{\mathrm{q}_{4}\right\}$
c) $\left\{\mathrm{q}_{3}, \mathrm{q}_{4}\right\} \leq\left\{\mathrm{q}_{3}\right\} \quad$ és $\quad\left\{\mathrm{q}_{3}, \mathrm{q}_{4}\right\} \leq\left\{\mathrm{q}_{4}\right\}$ 
Továbbá, a világtudásunk alapján, valamint amiatt, hogy a predikátum alanya ágens thematikus szerepü, fennállnak az alábbi következtetések (Varasdi (2006), 45. oldal):
i) walkTo(john,bank) $\rightarrow$ intend(walkTo(john,bank))
ii) walkTo(john,post) $\rightarrow$ intend(walkTo(john, post))
iii) walkTo(john,bank) $\rightarrow$ walkToward(john,bank)
iv) walkTo(john,post) $\rightarrow$ walkToward(john,post)

Két példát hozok azok közül, amelyeken Varasdi (2006) szemlélteti az egyes szituációk esetében elhangzó progresszív mondatok igazságértékének megállapítását (Varasdi (2006), 47. oldal):

I. Ha $\langle\mathrm{w}, \mathrm{t}\rangle$-nél John a bank felé (és így természetesen a posta felé is) gyalogol, és szándékában áll a bankba menni, akkor a John épp megy a bankba mondattal írjuk le a szituációt. Ebben az esetben a $\langle\mathrm{w}, \mathrm{t}\rangle$ által alátámasztott föszürők a $\left\{\mathrm{q}_{3}, \mathrm{q}_{4}\right\}$, és a $\left\{\mathrm{q}_{1}, \mathrm{q}_{3}, \mathrm{q}_{4}\right\}$, vagyis két progresszív mondat igaz ebben az esetben: John épp megy a bankba vagy a postára, és a John épp megy a bankba. Mivel azonban a két föszürő közül $\operatorname{csak}\left\{\mathrm{q}_{1}, \mathrm{q}_{3}, \mathrm{q}_{4}\right\}$ maximális, így a specifikusabb progresszív mondat lesz a Prog* értelmében is igaz: John épp megy a bankba. Ez épp az, amelyikkel a szituációt intuitív alapon leírtuk.

II. Ha Johnnak szándékában áll elmenni a bankba, de mozdulatlanul áll, akkor nincs olyan propozíció, amelyik progresszívként igaz lenne. Ennek oka, hogy bár $\mathrm{q}_{1}$ igaz, hiszen a szándék létezik, de mind $\mathrm{q}_{3}$, mind $\mathrm{q}_{4}$ hamis, ezért nincs alátámasztott főszürő. Így sem Prog, sem Prog* nem lesz igaz egyik propozíció esetében sem. 
Varasdi megoldása helyesen jósolja meg az egyes esetekben a különböző progresszív mondatok elfogadhatóságát és kezelni tudja a multiple-choice paradoxont (lásd 2.1.1. fejezet, 5. lábjegyzet).

\subsection{Extenzionális modellek}

Extenzionálisként azokra a modellekre hivatkozom, amelyekben a progresszív mondatok interpretációjához nem szükségesek az aktuális világ mellett lehetséges világok. Bár jól megalapozott a motivációja az intenzionális elméleteknek, amelyek a progresszív szemantikáját a modalitás bevonásával adják meg, léteznek olyan megoldások, amelyek ezt nem tartják szükségesnek, és extenzionális keretben maradva egyszerübb megoldást javasolnak. A következőkben a két legmeghatározóbb ilyen elméletet ismertetem.

\subsubsection{Parsons (1989): Befejezetlen tárgyak}

Parsons egy eseményalapú modellt ad, amelyben az időintervallumok és individuumok mellett vannak cselekvések (process), telikus események (events) és állapotok (states). ${ }^{14}$ A telikus eseményeknek szerinte gyakran összetett szerkezet tulajdonítható, mert van egy fejlődési (development) és egy kulminációs részük. Alapvető fontosságú megállapítása azonban az, hogy nem minden telikus esemény rendelkezik kulminációs résszel. A különböző eseménytípusokat két, az események és időintervallumok közötti reláció segítségével adja meg (Parsons (1989) 220. oldal):

\footnotetext{
${ }^{14}$ Parsons (1989) a különböző eseménytípusokra együttesen Bach (1981) után az eventuality terminust használja. Magyarul azonban erre az esemény terminust használjuk, ezért a továbbiakban én a Parsons-féle eseményeket fogom telikus eseményként megkülönböztetni az állapotoktól és a cselekvésektől. Az esemény terminust pedig az eventuality terminus megfelelöjeként használom.
} 
„A 'Cul(e,t)' jelöléssel azt fejezem ki, hogy e egy olyan telikus esemény, amely t-nél kulminál. Amikor azt mondom, hogy egy e esemény fennáll (hold) (t-nél), az vagy azt jelenti, hogy az e esemény egy állapot és az e esemény tárgya az e állapotban van t-nél, vagy azt jelenti, hogy e egy olyan telikus esemény, amely a fejlödési szakaszban van t-nél. (A 'Hold(e,t)' jelölést használom annak kifejezésére, hogy egy e esemény fennáll (hold) t-nél.)",15

Parsons tehát egyszerủen különböző tulajdonságokkal jellemzi a telikus eseményeket és az állapotokat, és ez utóbbihoz tartozónak tekinti a progresszív telikus eseményeket is. Ami a cselekvéseket illeti, azokat speciális telikus eseményeknek tekinti, tehát a $C u l$ reláció segítségével adja meg. Az oszthatóság tulajdonsága alapján olyan eseményként kezeli a cselekvéseket, amelyek több, egymást átfedő részeseményből állnak össze, és ezek a részesemények egyenként kulminálnak. Például az Agatha ran. 'Agatha futott' mondat esetében a futási eseménynek egy része is ugyanolyan futási esemény, mint az egész futás, és pusztán nyelvhasználati konvenció miatt gondolunk Agatha futásáról beszélve a maximális eseményre, nem pedig pusztán egy részére. Mivel így a cselekvések (activity) is telikus eseménynek minősülnek, a progresszív cselekvések tehát a telikus eseményekkel egységesen kezelhetők. Vagyis ha egy esemény progresszív, akkor akár atelikus, akár telikus eseményről van szó, inherens tulajdonsága, hogy fennáll (Hold), ha pedig nem progresszív eseményről van szó (akár atelikus, akár telikus), akkor inherens tulajdonsága, hogy kulminál $(C u l)$. Parsons tehát nem a kiteljesedett eseményhez képest adja meg a progresszív eseményt, hanem két különbözö, inherens tulajdonság segítségével jellemzi azokat: ha állítjuk egy eseményről, hogy fennáll (Hold), abból nem következik, hogy kulminálnia kellene $(C u l)$ - ezért az imperfektív paradoxon és a megszakítás problémája nem merül fel.

Ami a megszakítás problémáját illeti, láttuk, hogy az intenzionális modellek bár az aktuális világban nem feltételezik a megszakadt esemény folytatását - a lehetséges

15 O.M. fordítása, az eredeti szöveg: „I use the notation ' $\mathbf{C u l ( e , t ) ' ~ t o ~ m e a n ~ t h a t ~ e ~ i s ~ a n ~ e v e n t ~ t h a t ~}$ culminates at time $t$. When I say that an eventuality e holds (at time $t$ ), I mean that either e is a state and e's object is in the state e at $t$, or e is an event which is in development at t. (I use the notation 'Hold(e,t)' for 'e holds at t'.)" 
világok alkalmazásával mégis a telikus esemény kulminációjára építik a progresszív szemantikáját. Parsons erről ezt írja (Parsons (1989), 221-222. oldal):

\begin{abstract}
„, The inertia worlds approach focusses on the idea of what would be the case (described in nonprogressive terms) if present activities were to go uninterrupted. I suggest that it is the present activities that are the whole story. " 16,17
\end{abstract}

Ahogy már korábban szó volt róla, Parsons (1989) viszont eleve nem feltételezi minden telikus eseményröl, hogy kulminál, vagyis vannak a világban kiteljesedett és nem kiteljesedett telikus események egyaránt, amelyek különböző inherens tulajdonsággal rendelkeznek. A létrehozást kifejező igékre (verbs of creation) nézve azonban ez határozott következménnyel jár.

\title{
26. Mary is building a house. \\ Mary épít-JELEN PROG egy ház \\ 'Mary házat épít.'
}

A fenti mondat egy valós házépítési eseményt ír le, és mivel progresszív alakról van szó, a Hold predikátummal adható meg, nem is várjuk, hogy kulmináljon. Parsons megállapítja, hogy ennek a megoldásnak az a következménye, hogy feltételeznünk kell részlegesen létrejött objektumokat, a (26)-os mondat esetében egy részben elkészült, befejezetlen házat. Parsons álláspontja szerint itt valójában nem ontológiai problémáról van szó, hiszen valóban léteznek félbe maradt objektumok a világban. A lényeg az, hogy egy ilyen félkész objektum esetében is ugyanazt a jelölést használjuk, mint egy kész esetében, vagyis a félkész házat is háznak nevezzük. Ez azonban nyelvhasználati kérdés,

\footnotetext{
${ }^{16}$ A kiemelés O.M. jelölése. Az idézett mondatot Varasdi Károly ajánlotta a figyelmembe, amit ezúton is köszönök neki.

${ }^{17}$ O.M. fordítása: „Az inerciavilágokon alapuló megközelítés arra fókuszál, hogy mi lenne a helyzet (nem progresszívként megadva), ha a jelenben zajló cselekvések megszakítatlanul folytatódnának. Meggyőződésem, hogy csakis a jelenben zajló cselekvések azok, amik számítanak.”
} 
amit a (27)-es példa mutat, amely még csak nem is progresszív (Parsons (1989), 226227. oldal).

27. Sam put the cake in the oven.

Sam betesz-MÚLT a süti ELÖLJ-be a sütő

'Sam betette a sütit a sütőbe.'

After he blend it and mixed it, he put in the oven.

Után ő összeállít-MÚLT az és kever-MÚLT az ő betesz-MÚLT az ELÖLJ-be a sütő 'Miután összeállította és összekeverte, betette a sütőbe.'

28. - What are you doing this morning?

Mi van-JELEN-E/2 te csinál-PROG ez reggel

'Mit csinálsz ma délelőtt?'

- I am making a cake.

Én csinál-JELEN PROG egy süti

'Süteményt sütök.'

A (27)-es példában még jóval a tényleges létrejötte előtt süteményről beszélünk, (28) pedig még bármiféle előkészületet megelőzően hangzik el. Parsons megállapítja, hogy bár (28) esetében a progresszív jövőidejü olvasatáról van szó, általánosan nehéz meghatározni, hogy mely elemek tartoznak már egy esemény előkészületéhez, és melyek azok, amelyek még nem. Tehát gyakran nehéz elkülöníteni a progresszív éppen zajló és jövőidejű eseményre utaló olvasatát, amely nehézség azonban elmélettől függetlenül létezik. A félkész objektumok feltételezése pedig - ahogy láttuk - nem intuícióellenes.

Parsons tehát valós befejezetlen objektumokat feltételez, és a folyamatban lévő eseményeket nem a kiteljesedettekhez képest adja meg, hanem azoktól függetlenül. Ezzel a megoldással megmarad az aktuális világban. 


\subsubsection{Kearns (1991)}

Kearns az angol progresszív temporális tulajdonságait vizsgálva megállapítja, hogy a progresszív puszta egyidejüségként adható meg. Elfogadja Leech (1969) és Dowty (1979) érvelését, miszerint a Bennett - Partee-féle, valódi temporális keretként való értelmezés túl szigorú, mert a valódi részhalmaz kikötés, illetve hogy $t$ nem lehet záró pillanata az eseménynek, túlzott elvárások. Leech erre a problémára adott megoldását viszont túl lazának tartja. Leech szerint ugyanis egy progresszívben álló mondat esetén (például John was playing the piano from ten to eleven. 'John 10 és 11 között zongorázott.') az esemény valódi időtartamáról nem tudunk semmit. Kearns szerint Leech-nek ez a megállapítása azonban megengedi azt is, hogy az esemény valódi ideje rövidebb legyen, mint a referenciaidőként megadott időintervallum $(t)$, ezért a következő definíciót adja:

(4) [PROGa] akkor és csak akkor igaz t-nél, ha létezik olyan I intervallum, amelynek trészhalmaza, és $\alpha$ igaz I-nél. ${ }^{18}$

Kearns tehát a valódi részhalmaz reláció helyett az egyenlőséget is megengedő részhalmaz relációt használ, ezáltal nem követeli meg az esemény folytatódását. Annak a kikötésnek az elhagyásával pedig, hogy $t$ nem lehet befejező intervallum, nem követeli meg az esemény korábbi kezdődését, vagyis megengedi a puszta egyidejűséget. Kearns szerint ugyanis a progresszív esemény temporális keretként való értelmezése nem következmény, csupán implikatúra. Érvelését a főnévi tartományban megfigyelhető párhuzammal támasztja alá (Kearns (1991) példái: 39. old. (7a-c), 44. old. (14) és (15)):

29. a) I have

ten books.

$q$

Én birtokol-JELEN-E/1 tíz könyv-TSZ

18 ,, $[\mathrm{PROG} \alpha]$ is true at $\mathrm{t}$ iff there exists an interval I such that $\mathrm{t}$ is a subset of $\mathrm{I}$, and $\alpha$ is true at t." (Kearns (1991), 43. oldal) 
'Van tíz könyvem.'

b) I have at least ten books. $p$

Én birtokol-JELEN-E/1 legalább tíz könyv-TSZ

'Van legalább tíz könyvem.'

c) I have more than ten books.

Én birtokol-JELEN-E/1 több mint tíz könyv-TSZ

' Több mint tíz könyvem van.'

30. a) I played the piano from 10 to 11

Én játszik-MÚLT a zongora ELÖLJ-től 10 ELÖLJ -ig 11

'10-től 11-ig zongoráztam.'

b) I was playing the piano from $\quad 10$ to 11 .

Én játszik-MÚLT PROG a zongora ELÖLJ-től 10 ELÖLJ-ig 11

'10 és 11 között (épp) zongoráztam.'

A (29b) mondatot az teszi igazzá, ha pontosan tíz, vagy több mint tíz könyvem van ( $p$ iff $q$ v r). Kearns megállapítja, hogy a (29a) és (29b) közti különbség Grice mennyiségi maximájával magyarázható. Grice mennyiségi maximája azt az elvárást fogalmazza meg, hogy a lehető leginformatívabbak legyünk, vagyis a lehető legpontosabban fogalmazzunk. Két igaz állítás közül tehát az a megfelelőbb, amelyik a több információt tartalmazza, azaz specifikusabb. A fenti példák esetében (29a) és (29b) egyformán igaz, ha pontosan tíz könyvem van, és (29b) akkor is igaz, ha több mint tíz könyvem van. (29a) a (29b)-vel szemben állva tehát azt jelenti, hogy pontosan tíz könyvem van, vagyis specifikusabb, több információt tartalmaz, mint (29b), mert (29b)-vel szemben itt pontosan tudom a könyvek számát. Grice mennyiségi maximájának értelmében ha (29a) helyett (29b)-t választom, akkor ezt azért teszem, mert a (29b) által hordozott információ a lehető legtöbb, amivel rendelkezem, és ez nem elég ahhoz, hogy (29a)-t használjam. A 
(30a-b) mondatok kapcsán ugyanez mondható el. Ha rendelkeznék minden információval ahhoz, hogy pontosan meg tudjam mondani, hogy mettől meddig zongoráztam, a (30a) mondatot választanám. De mivel nem rendelkezem ennyi információval, a lehető legspecifikusabb kijelentés, amit tehetek, a (30b). Ezzel egyúttal előhívom azt az implikatúrát, amivel (30b) rendelkezik, és ami a kisebb fokú specifikusságot okozza, hiszen a mondat igazságának többféle teljesülését teszi lehetővé.

A példák alapján tehát a progresszív mondatot az teszi igazzá, ha az adott esemény a megjelölt időintervallumra igaz, vagy ha a megjelöltnél hosszabb időintervallumra igaz. Kearns ennek megfelelően a következő definíciót adja meg, hogy tisztábban látsszon a diszjunkció, amelyből az implikatúra ered (Kearns (1991), 43. oldal):

(5) [PROGa] akkor és csak akkor igaz t-nél, ha a igaz t-nél, vagy létezik olyan t', amelynek $t$ valódi részhalmaza, és $\alpha$ igaz t'-nél. ${ }^{19}$

Bár Kearns az érvelésében hosszabb intervallumot használt referenciaidőként (from 10 to 11 'tíztől tizenegyig' vagy 'tíz és tizenegy között' (lásd (30)), a megadott definíció szempontjából közömbös, hogy ez az intervallum milyen hosszú, vagyis a minimális intervallumok, azaz időpontok esetében is ugyanúgy áll. Megjegyzi, hogy ha a referenciaidő időpont, akkor az implikáció, a temporális keretként való értelmezés erősebb, de ez is csak a világról meglévő tudásunk következménye, nem pedig a progresszív aspektus igazságfeltételekkel megadható szemantikájáé.

\footnotetext{
${ }^{19}$ O.M. fordítása, az eredeti szöveg: ,, [PROG $\left.\alpha\right]$ is true at $t$ iff $\alpha$ is true at $t$ or there is a time $t$ ' such that $t$ is a proper subset of $t$ ' and $\alpha$ is true at $t^{\prime}$."
} 


\section{A progresszív a magyarban}

\subsection{Kiefer aspektuális rendszere}

A magyar vonatkozású aspektuális szakirodalom legátfogóbb munkája Kiefer Ferenc elmélete (1992a,b, 1994, 2006, 2009), amely szintén a vendleri alapokra épít, de aspektusfogalma eltér attól a nézőpont aspektus fogalomtól, amelynek a tárgyalt progresszív aspektus az egyik típusa.

A nézőpont aspektus Smith (1991) kétkomponensü aspektuselméletének egyik terminusa. Smith kétféle aspektust különböztet meg: a szituációs aspektust vagy típust (situation type), illetve a nézőpont aspektust (viewpoint aspect). Elméletének lényege, hogy a két komponens egymástól független, bár azt elismeri, hogy a mondat aspektuális értéke ezeknek az együttműködésével jön létre. Smith szerint az aspektuális alapkategóriák az Univerzális Grammatika részei, hiszen humán kognitív képességeken alapulnak, vagyis nyelvfüggetlenek.

Az általa szituációtípusnak vagy szituációs aspektusnak nevezett komponens lényegében a vendleri kategóriáknak felel meg, az események belső időszerkezetét takarja. $^{20} \mathrm{~A}$ Vendler által megadott négy kategórián kívül azonban egy további osztályt sorol ide, a szemelfaktívok osztályát. Az egyes kategóriák között a dinamizmus, durativitás és telikusság tulajdonságával tehetünk különbséget.

A másik aspektus a nézőpont aspektus. Minden mondat rendelkezik nézőponttal, ami kimondottan a beszélő választása az események tálalásának módjához, és független a szituációs aspektustól, hiszen alapvetően minden szituációs aspektusú esemény láttatható minden nézőpontból. Három nézőpont aspektust különböztet meg: a progresszívet, a perfektívet és a semlegest.

\footnotetext{
${ }^{20}$ Ezt az aspektusfogalmat takarja tulajdonképpen az akcióminőség (actionsart) terminus az angolszász hagyományban. A terminust Kiefer is használja, de ő az akcióminőséget kimondottan morfoszintaktikai kategóriának tekinti. A vendleri osztályokat ugyanakkor eseményszerkezeti osztályoknak nevezi, és az eredeti négy osztálynál jóval többet állapít meg (Kiefer (2006), 205-216. oldal).
} 
Kiefer aspektusfogalma azonban sem a szituációtípus, sem a nézőpont aspektus fogalmával nem egyezik. Ö Vendler osztályozását nem aspektuális, hanem eseményszerkezeti osztályozásnak tekinti. Ezt azzal indokolja, hogy a megadott osztályok közül több azonos aspektusú, például a teljesítmények és az eredmények egyaránt befejezett aspektusúak. Kiefer megállapítja továbbá, hogy a Vendler által megadottaknál jóval több kategóriát lehet megkülönböztetni. Vendler két tesztet használt a négy igeosztály megállapításához: az egyik teszt az, hogy az adott ige állhat-e progresszív konstrukcióban, a másik pedig az, hogy milyen időhatározóval fér össze. ${ }^{21}$ Kiefer elsősorban az utóbbi tesztet alkalmazza az eseménytípusok megállapításához, de egyrészt több időhatározót von be a vizsgálatba, másrészt néhány kiegészítő tesztet is használ (például módhatározókkal való kompatibilitás, szintaktikai alternációk megléte). Kiefer (2006) szerint az eseménytípusok meghatározása az eseményszerkezetes szemantikai ábrázoláson alapszik:

\begin{abstract}
„Eseményszerkezeten olyan szemantikai ábrázolást értünk, amely tartalmazza az események részeseményeit és a közöttük lévő időbeli viszonyokat, továbbá feltünteti a részesemények szereplöit." (Kiefer (2006), 220. oldal)
\end{abstract}

Kiefer (2006) még tovább finomítja ezt az ábrázolási módot azzal, hogy más szempontokat is figyelembe vesz, például az esemény utóállapotának visszafordíthatóságát. Mindezek alapján jóval több eseménytípust különböztet meg, mint Vendler, és a következő definíciót adja a besoroláshoz:
„Ha két igeosztály az időmódosítók esetében különbözö kompatibilitási feltételeknek engedelmeskedik, akkor a két igeosztály két különbözö eseménytípust fejez ki." (Kiefer (2006), 224. oldal) ${ }^{22}$

\footnotetext{
${ }^{21}$ Kiefer a Vendler által használt időhatározókat időmódosítóknak nevezi. Az időmódosítók részletes tárgyalását lásd a 3.3.2. fejezetben.

22 A dolgozat témája szempontjából az eseménytípus és az aspektus viszonya fontos, nem az egyes eseménytípusok, ezért itt nem sorolom fel az általa megállapított típusokat.
} 
Kiefer hangsúlyozza az eseménytípus fogalma és az aspektus fogalma közti különbséget. Az aspektust mondatszemantikai kategóriának tartja, és így definiálja:

„A mondataspektus a mondat belsö időszerkezetét fejezi ki.” (Kiefer (2006), 26. oldal)

Az egyik alapvető különbség Kiefer aspektusfogalma és a Smith-féle nézőpont aspektus fogalom között, hogy Kiefer az általa definiált aspektust - amelybe beletartozik a progresszív aspektuális kategória is - az eseményszerkezetből levezethetőnek tekinti, míg Smith az általa definiált aspektust - amelybe szintén beletartozik a progresszív aspektus - az eseményszerkezettől függetlennek tekinti. Kiefer az aspektust Smith szituációs aspektusához hasonlóan kompozicionálisnak tartja, vagyis az ige lexikailag adott aspektusa mondatszinten nála is megváltozhat. Ez arra utal, hogy Kiefer aspektus fogalma inkább Smith szituációs aspektusához áll közel, nem a nézőpont aspektushoz. Ez viszont azt jelenti, hogy mindketten máshova sorolják a progresszív aspektust.

Kiefer a külső (múlt, jelen, jövő) és belső időszerkezet (aspektus) tárgyalása kapcsán a következőt állapítja meg:

„,...A mondat belső időszerkezete ezzel szemben független a beszédidőtöl, és az események, történések, folyamatok idöbeli lefolyásának módját jelöli. A belsö időszerkezet tehát nem függ a naptári idöt jelölö időhatározóktól, szerepet benne csak olyan időhatározók kaphatnak, amelyek az események, történések, folyamatok időbeli lefolyását érintik." (Kiefer (2006), 15-16. oldal)

Ez a megállapítás több szempontból is problematikus. Az egyik gond az, hogy bár Kiefer szigorúan elválasztja az aspektust az eseményszerkezettől, mindkettőt időmódosítók segítségével határozza meg. A másik probléma az, hogy az időmódosítók nem mindegyik általa megadott aspektuális kategória esetében kaphatnak szerepet: ilyen 
például a progresszív, amely nem türi meg az időmódosítókat (részletesen lásd 3.3.1. fejezet).

Kiefer három aspektuális alapkategóriát különböztet meg. A folyamatos és befejezett aspektus dichotómiát alkot, ezek oszthatóság szempontjából különböznek. Míg a folyamatos aspektusú események oszthatóak, a befejezettek nem. A harmadik alapvető aspektuális kategória az állapotoké, amit Kiefer elsősorban azzal indokol, hogy a folyamatos aspektusú igéktől eltérően az állapotok nem tehetők befejezetté, és a folyamatos aspektusra jellemző teszteknek, az idő-, illetve módhatározókkal való kompatibilitásnak az állapotok nem felelnek meg. További aspektuális kategóriának tartja ugyanakkor a tartósság - pillanatnyiság dichotómiát is, illetve a folyamatos aspektus esetében a korlátlan, illetve korlátozott idővonatkozást. Ezek alapján Kiefer (2006) a következő aspektuális rendszert adja meg:

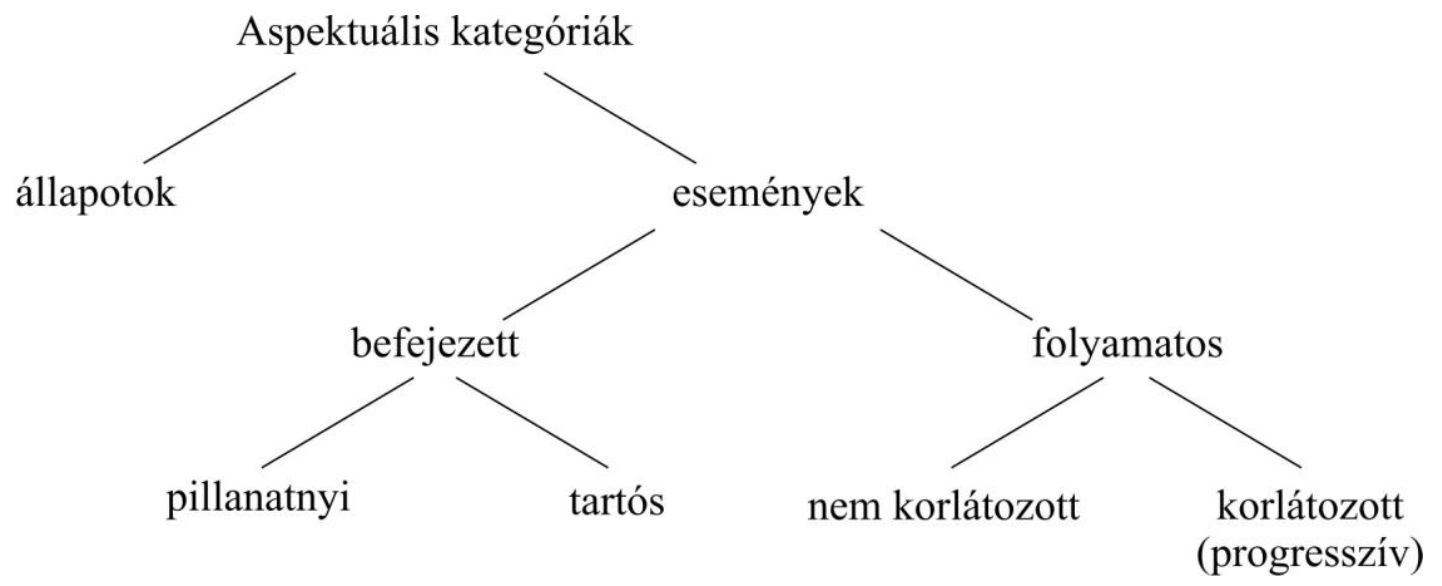

1. ábra

Az osztályozással kapcsolatban megjegyzi, hogy bővíthető, ha az ismételhetőség tulajdonságát is figyelembe vesszük. Problematikusnak tartja ugyanakkor, hogy a progresszív aspektus több szempontból is kilóg az osztályozásból, mivel a folyamatos aspektusra jellemző tulajdonságok közül soknak nem felel meg, és nem vesz részt a folyamatos - befejezett szembenállásban. Kiefer szerint a megoldás az lehet, ha a progresszív aspektust a folyamatos és befejezett eseményekkel szemben álló kategóriának tekintjük. A fenti osztályozás azonban a progresszív aspektus 
kategóriájától eltekintve teljesen azonos a Vendler által megadott osztályozással. Az állapotok (states) kategóriája mindkét rendszerben szerepel, Kiefer pillanatnyi befejezett esemény kategóriája Vendler eredményige (achievement) kategóriájának felel meg, a tartós befejezett esemény kategóriája a teljesítményige (accomplishment) kategóriájának, a nem korlátozott folyamatos esemény pedig a cselekvésigék (activity) kategóriájának. Valójában tehát Kiefer aspektuális osztályozása eseménytípusokat jelöl - tulajdonképpen Smith szituációs aspektusaival egyezik -, az általa megadott fó aspektuális kategóriák (folyamatos, befejezett) pedig csak egyes tulajdonságok alapján létrejött fölöttes kategóriák.

\subsection{A progresszív aspektust kifejező grammatikai eszközök}

Ami a magyart illeti, nem tudunk megadni egy olyan morfémát, mondatszerkezetet vagy akár intonációs sémát, ami egyértelmüen meghatározza a progresszív nézőpont aspektust. Kiefer szerint a progresszív mondat eseménye hiányos időszerkezetü, és a mellékmondat teszi teljessé ezt az időszerkezetet. A progresszív aspektus tipikus szerkezeteként az Épp..., amikor... szerkezetre szokás hivatkozni. Vannak azonban olyan progresszív mondatok, amelyek nem ilyen szerkezetüek, és mégis temporális keret olvasatot kapnak:

\section{Aurél úszik.}

A fenti mondatnak legalább két olvasata van. Az egyik a progresszív értelmezés, amely szerint a beszédidő pillanatában Aurél épp rója a hosszokat a medencében, vagyis a beszédidőhöz képest az esemény temporális keretként jelenik meg. ${ }^{23}$ A másik olvasat szerint Aurél a sportok közül az úszásnak hódol, vagyis a predikátum habituális

\footnotetext{
${ }^{23}$ A mondat beszédidőhöz való kötése természetesen az ige jelen idejéből adódik. A habituális és a progresszív olvasat egyidejủ megléte azonban igeidőtől független, a többértelmüség múlt és jövő időben egyaránt megvan.
} 
értelmezésű, egy Aurélra jellemző szokást, tulajdonságot jelöl. Az angol a két olvasatot két különböző igeragozási paradigmával jelöli:

32. Aurél is swimming.

Aurél úszik-JELEN PROG

'Aurél éppen úszik.'

33. Aurél swims.

Aurél úszik-JELEN-E/3

'Aurél úszik (úszó).'

Az angolban a progresszív aspektus egyértelmű kifejezője a continuous igei szerkezet (létige $+\mathrm{V}$-ing). A megfelelés azonban csak egyirányú, mert azt nem mondhatjuk, hogy ez az igeragozás mindig a progresszív aspektust fejezi ki. Ezt vizsgálja Kratzer (1995) amellett érvelve, hogy a simple present alakkal szemben a continuous alak egy eseménynek nem is annyira a progresszivitását, hanem az aktuális, megvalósult jellegét fejezi ki, ami szükségszerüen annak térben és időben való kötöttségét eredményezi.

A magyar nyelvre rátérve: vannak olyan mondatok, amelyek a Kiefer által megadott (Épp..., amikor ...) szerkezetűek, mégsem progresszív olvasatúak:

\section{4. Épp tüsszentettem, amikor megszólalt a telefon (..., ezért nem hallottam.)}

A fenti mondat tipikus szerkezete ellenére nyilvánvalóan nem progresszív olvasatú, hiszen mindkét eseménye pillanatnyi esemény (szemelfaktív), eseményszerkezetük egyetlen pontszerü részeseményből áll, aminek következtében a tüsszentés nem értelmeződhet keretként a telefon megszólalásához képest. A jellegzetes intonációs séma és mondatszerkezet mellett még az igekötős igék igekötőjének ige mögötti pozícióját szokás a progresszív mondat grammatikai jegyeként megjelölni. Az ige+igekötő sorrend azonban szintén nem egyértelmű azonosító jegy, mert egyrészt az igekötő nemcsak a progresszív aspektus következtében kerülhet az ige mögé, hanem például fókusz 
jelenléte miatt is, másrészt pedig vannak olyan igekötős igék is, amelyek progresszív aspektusú mondatban is igekötö+ige sorrendet mutatnak.

Az igék progresszív mondatban mutatott eltérő szintaktikai viselkedésére próbál magyarázatot adni Piñón (1995) amellett érvelve, hogy az ige pozíciója szemantikailag motivált szintaktikai mozgatások eredménye. Piñón (1995) megkülönböztet egyszerü és összetett igéket, az utóbbi csoportba sorolja azokat, amelyek igekötővel vagy puszta köznévvel állnak. A puszta köznevek viselkedése e tekintetben megegyezik az igekötőkével, ezért csak az igekötős példákat hozom. Piñón a következő variációkat veszi számba (Piñón (1995) példája, (1)):

35. a) Tamás éppen fözött a konyhában, amikor Réka bejött. (PROG)

b) Tamás fél óra hosszat fözött a konyhában.

A (35a-b)-ben szereplő föz ige atelikus, cselekvésige és egyszerü. Képezhető vele progresszív mondat, amit (35a) jólformáltsága mutat. Mind a nem progresszív, mind a progresszív mondatban azonos alakban szerepel (Piñón (1995) példái, (2), (4)).

36. a) Mari éppen felolvasott a tanteremben, amikor Réka bement. (PROG)

a') \#Mari éppen olvasott fel a tanteremben, amikor Réka bement. (PROG)

b) Mari fél óra hosszat felolvasott a tanteremben.

37. a) Mari éppen vitte le a bort, amikor csöngettek. (PROG)

a') \#Mari levitte a bort, amikor csöngettek. (PROG)

b) Mari öt perc alatt levitte a bort.

A (36-37)-ben szereplő összetett igék állhatnak progresszív mondatban, de különböző viselkedési mintát mutatnak. A progresszív (36a) mondatban az ige a nem progresszív (36b)-hez képest változatlan alakban szerepel, igekötő+ige sorrenddel, és fordított sorrenddel nem is jólformált. Ezzel szemben a progresszív (37a) mondatban az 
ige+igekötő sorrend jólformált, a fordítottja a nem progresszív (37b)-nek. ${ }^{24}$ A két példában szereplö igék között az a különbség, hogy míg a (36)-beli felolvas ige cselekvésige, tehát atelikus, addig a (37)-ben szereplő levisz ige teljesítményige, vagyis telikus. Ezt mutatják a b) példákban a nem dőlttel kiemelt időmódosítók. Piñón ezek alapján a következő általánosítást fogalmazza meg:

A: Minden semleges mondatban álló összetett ige ha atelikus predikátum, akkor:

Progresszív olvasat esetén igekötő+ige alakban áll.

B: Minden semleges mondatban álló összetett ige ha telikus predikátum, akkor:

Progresszív olvasat esetén ige+igekötő alakban áll.

A következő példák árnyalják ezt a megkülönböztetést, hiszen vannak olyan telikus igék - mind az egyszerüek, mind az összetettek között -, amelyek egyáltalán nem állhatnak progresszív alakban (Piñón (1995) példái, (5), (7)):

38. a) \#Réka szívta el a cigarettáját, amikor Tamás bejött. (PROG)

b) \#Réka (éppen) elszívta a cigarettáját, amikor Tamás bejött. (PROG)

39. \#Réka éppen kapott egy levelet, amikor Tamás megérkezett. (PROG)

A (38-39)-es példák egyike sem értelmezhető progresszívként, bár nem progresszívként tökéletesek. A (35-37)-es példák alapján egyértelmü, hogy ennek az oka nem lehet sem a telikusság - hiszen (37a) telikus és progresszív aspektusú -, sem az ige összetettsége vagy annak hiánya, hiszen (38)-ban összetett ige áll, (39)-ben pedig egyszerü. Piñón szerint a (38)-ban és a (39)-ben szereplő igék aspektuálisan különbözőek, amit a majdnem határozó segítségével mutat ki (Piñón (1995) példái, (13), (14)):

40. a) Réka majdnem kapott egy levelet.

\footnotetext{
${ }^{24}$ A (37a’) tökéletes mondat, de nem kaphat progresszív értelmezést, progresszívként nem jólformált.
} 
b) Réka majdnem elszívta a cigarettáját.

A két mondat esetében a módosítás más-más eredménnyel jár. (40a) egyértelmủen azt jelenti, hogy Réka egyáltalán nem kapott levelet. Ezzel szemben (40b)-nek két olvasata van: az egyik megegyezik (40a) olvasatával, eszerint Réka el sem kezdte a cigarettázást, a másik olvasat szerint elkezdte ugyan, de még nem fejezte be. Piñón szerint (40b)-nek ez az olvasata azt mutatja, hogy itt - (40a)-val szemben - nem pillanatnyi eseményt kifejező igéről van szó. Ez viszont azt jelenti, hogy még ha (39) lehetetlen progresszív olvasata indokolható is a benne szereplő összetett ige pillanatnyiságával, (38a-b)-é semmiképp sem.

Arra kell tehát magyarázatot találni, hogy bizonyos telikus összetett igék miért nem állhatnak progresszív alakban az igekötő és ige sorrendjétől függetlenül. Piñón (1995) megállapítja, hogy a progresszív általában elfogadhatóbb olyan összetett igék esetében, amelyeknek az igekötője megőrizte az eredeti téri jelentését, vagy pedig kifejlődött egy másik olyan jelentése, amely a téri jelentésen alapszik. ${ }^{25}$ Ilyenre példák az alábbiak (Piñón (1995) példái, (17a-b)):

\section{Tamás kente be a padlót viasszal, amikor Réka bejött. (PROG) \\ 42. Réka nyitotta ki az ajtót, amikor a madár berepült. (PROG)}

A fentiek alapján Piñón a következőképp módosítja a B általánosítást:

B': Minden semleges mondatban álló összetett ige ha (nem pillanatnyi) telikus predikátum, akkor progresszív olvasatú akkor és csak akkor, ha ige+igekötő alakban áll, és a jelentése kompozicionális.

Az A-ban és B'-ben megfogalmazott általánosítás alapján tehát az összetett igék közül a cselekvéseket kifejezők változatlan alakban állnak a progresszív mondatban, a

\footnotetext{
${ }^{25}$ Lásd erről bővebben Kiefer (1992a), (95-96). (Piñón (1995) hivatkozása), valamint Kiefer (2006), 48. oldal.
} 
teljesítményeket kifejezők azonban nem. Piñón szerint ez azt mutatja, hogy a cselekvéseket kifejezőkre közvetlenül alkalmazható a progresszív operátor, a teljesítményeket kifejezőkre viszont nem. Moens and Steedman (1988)-ra hivatkozva Piñón (1995) amellett foglal állást, hogy a progresszív operátor csak cselekvéseken tud müködni, ezért a teljesítményeket először cselekvésekké kell alakítani. ${ }^{26}$ Ennek megfelelően feltételez egy PR (process) operátort, ami a telikus predikátumokat atelikussá alakítja, és a PR operátor kimenetén müködhet a PROG (progresszív) operátor. Amennyiben eleve atelikus a predikátum, a PR operátor nem tud rajta müködni, mert számára bemenetként az nem megfelelö. Piñón szerint ezzel a szemantikai tartalommal motiválható egy olyan szintaktikai megoldás, amellyel a különböző igék progresszív mondatban megfigyelhető disztribúciója megadható. ${ }^{27}$

\subsection{A vizsgált nyelvi anyag}

Az alábbiakban meghatározom azoknak a mondatoknak a körét, amelyeket vizsgálni fogok. Bár feltehetően a vizsgálat is és az eredménye is kiterjeszthető a progresszív mondatok egy nagyobb körére, ebben a dolgozatban csak egy szük csoportra vonatkozóan fogalmazom meg az állításaimat.

\section{3. Épp telefonáltam, amikor eleredt az esö.}

A (43)-as mondat valójában két különböző állítást fejez ki. A két mondatnak némileg talán eltér az intonációja is, de a köztük lévő különbség leginkább abban érhető tetten, hogy különbözőképpen vesznek részt a diskurzus felépítésében. Ezt mutatja, hogy a két esetben eltérő módon folytathatjuk a diskurzust (lásd (44a) és (45a)).

\footnotetext{
${ }^{26}$ Moens and Steedman (1988), 17.: , For example, we shall argue below that the progressive auxiliary demands that its argument be a process, which it predicates as ongoing."

${ }^{27}$ A dolgozat tárgya szempontjából azonban ez nem releváns, ezért nem ismertetem.
} 
44. a) Épp telefonon beszéltem Auréllal, amikor eleredt az eső. De nem tartott sokáig, mert Aurélnak rohannia kellett valahová. Azt mondta, majd visszahív.

b) Amikor eleredt az esö, épp telefonon beszéltem Auréllal.

45. a) Épp telefonon beszéltem Auréllal, amikor (egyszer csak) eleredt az eső. De nem tartott sokáig, a fa koronája alatt még vizes sem lett a járda.

b) Amikor (*egyszer csak) eleredt az esö, épp telefonon beszéltem Auréllal.

A (46a) példában a folytatásból az derül ki, hogy a telefonálás nem tartott sokáig, míg (45a)-ban nyilvánvalóan az eső. Tehát a két esetben a mondatok közti anaforikus kapcsolatban más-más antecedensekre vonatkozhat az anafora. A két mondat közti különbséget jelzi az is, hogy míg a tagmondatok fölcserélésével kapott mondat (44b) esetében jólformált, (45b) esetében nem az. A (44a-b) példákban a progresszív mondat fömondati pozícióban van, (45a-b) esetében azonban nem. (44a) válaszként adható a Mit csináltál, amikor eleredt az eső? kérdésre. A dolgozatban csak olyan mondatokkal foglalkozom, amelyekben a progresszív aspektusú tagmondat főmondati pozícióban van. A fentihez hasonló kérdésre viszont az alábbi mondatok is mind megfelelő válaszok:

46. Mit csináltál tegnap délben /amikor eleredt az esö?

a) (Épp) füvet nyírtam.

b) Tegnap délben épp futottam.

c) Akkor épp aludtam.

d) Épp füvet nyírtam, amikor eleredt az esö.

A (46a-d) mondatok mind a referenciaidőre vonatkozó kérdésre válaszolnak, de nem mindegyikben jelenik meg nyíltan a referenciaidő. Az azonban elmondható, hogy mindegyik esetben valamilyen módon azonosítható, akár anaforával (lásd (46c)), a kontextusból (lásd (46a)), mellékmondat segítségével (lásd (46d)) vagy időhatározóval 
(lásd (46b)). Mindegyik esetben azonos szerepük van: jelölik a referenciaidőt, amelyhez képest a mondatban leírt esemény progresszívként értelmeződik. A dolgozatban azonban csak olyan mondatokat fogok szerepeltetni, amelyekben nyíltan megjelenik egy időhatározó.

\subsubsection{A progresszív megszorításai: az időmódosítók problémája}

A progresszív mondatok mind szintaktikailag, mind szemantikailag erősen megszorítottak. Ilyen megszorításpéldául az, hogy nem jelenhetnek meg bennük bizonyos típusú időhatározók. A következőkben az erre a megszorításra adott eddigi magyarázatokat ismertetem, majd később (lásd 3.3.4. fejezet) egy az eddigiektől eltérő megoldást javasolok.

Azokat az időhatározókat, amelyeket Vendler az igeosztályok elkülönítésére alkalmaz, Kiefer időmódosítóknak nevezi. Meghatározása szerint az időmódosítók olyan időhatározók, amelyek az esemény egy-egy részeseményét módosítják, további általános jellemzőjük, hogy nem állhatnak progresszív mondatban. Ezt a megszorítást egyébként az angolban is számon tartják, ahogy látni fogjuk.

Vendler az in prepozíciót tartalmazó 'valamennyi idő alatt' jelentésủ, továbbá for prepozíciót tartalmazó 'valamennyi időn át, ideig' jelentésű duratív időhatározók mellett az időpontjelölő at x time 'x időpontban' jelentésủ időhatározókat, valamint az igék progresszív alakban való megjelenésének lehetőségét is használja a teszteléshez. Ugyanazok az időmódosítók, amelyek a (47a), (48a) és (50a) példákban jólformált perfektív mondatot alkotnak a különböző típusú predikátumokkal, ugyanezekkel a predikátumokkal progresszív mondatban már nem jelenhetnek meg (lásd (47b), (48b), $(50 b-c))$.

47. a) Aurél fél óra alatt fölmászott a hegyre.

b) *Aurél fél óra alatt éppen mászott föl a hegyre. 
48. a) Aurél fél órán át futott.

b) * Aurél fél órán át éppen futott.

49. a) Aurél délben éppen mászott föl a hegyre.

b) Aurél délben éppen futott.

A vendleri osztályozás alapján a (47b) példában szereplő időmódosító (in 'valamennyi idő alatt') és a teljesítményige (fölmászik) kompatibilis, amit a (47a) mondat jólformáltsága is mutat, (47b) mégis rosszulformált. A két mondat között kizárólag aspektuális különbség van: míg (47b) progresszív, (47a) nem az. Ugyanez figyelhető meg (48b) és (48a) esetében. Az adott típusú időmódosító (for 'valamennyi ideig') és a cselekvésige (fut) kompatibilitása ellenére (48b) rosszulformált. A két mondat megint csak aspektusában tér el. A progresszív rosszulformált, a perfektív nem. A két példapár mutatja, hogy a grammatikalitásbeli különbség oka egyértelmüen a progresszív aspektus. (47b)-tól és (48b)-tól eltérően viszont (49a-b) a bennük szereplő igék típusától függetlenül jólformáltak, pedig progresszív aspektusúak. Ez vagy cáfolja azt a megállapítást, miszerint az időmódosítók nem jelenhetnek meg progresszív mondatban, vagy arra utal, hogy a benne szereplő időmódosító lényegét tekintve különbözik az előzőektől (lásd 3.3.2. és 3.3.3. fejezet).

Az időmódosítókkal való összeférhetetlenség magyarázatában Kiefer azt állítja, hogy a referenciaidőnek nemcsak az a szerepe, hogy hozzá képest értelmezzük a progresszív eseményt, hanem időmódosítóként is funkcionál. Továbbá, a referenciaidő olyan módon is meghatározza a progresszív eseményt, hogy az nem lehet sokkal hosszabb, mint ö maga. Mivel pedig ez az időpont időmódosító is, azért nem állhat a mondatban másik időmódosító, mert egy esemény referenciaidejét egyszerre csak egyféleképpen lehet módosítani.

A problémát Kearns (1991) is tárgyalja, és hasonló magyarázatot ad rá, de nem osztja azt az általános nézetet, miszerint a duratív időhatározók alapvetően nem férnek 
össze a progresszívvel. ${ }^{28}$ (50b-c) rosszulformáltságát elfogadja, de annak okát a két esetben másnak tulajdonítja. ${ }^{29}$ (Kearns (1991) példái: 179-180. oldal, (11-13))

50. a) It was raining for two hours.

EXPL esik-MÚLT PROG ELÖLJ két óra-TSZ

'Két órán át esett az eső.'

b) \#It was raining for two hours when I arrived.

EXPL esik-MÚLT PROG ELÖLJ két óra-TSZ amikor én érkezik-MÚLT

'Két órán át esett az eső, amikor megérkeztem.'

c) \#The level of the lake was rising ten feet when I arrived.

a szintELÖLL-GEN a tó emelkedik-MÚLTPROG tízláb-TSZ amikor énérkezik-MÚLT

'A tó szintje tízlábnyit emelkedett, amikor megérkeztem.'

Kearns szerint (50b-c) esetében a duratív időhatározó a referenciaidőt módosítja ugyanúgy, ahogy a mellékmondat (amikor megérkeztem) által kifejezett esemény ideje is. A rosszulformáltság oka az, hogy a megérkezés pillanatnyi eseménye által jelölt rövid, illetve az időhatározó által jelölt hosszabb intervallum nem fér össze egymással, pusztán eltérő terjedelmük miatt. Ennek a megoldásnak az alapján azonban a következő mondatoknak is jólformáltnak kellene lenniük:

51. a)\# Egy pillanat alatt mászott föl éppen a fára, amikor villámlott. b)\# Egy pillanatig éppen esett az eső, amikor megérkeztem.

\footnotetext{
${ }^{28}$ Kearns (Mittwoch 1988) megoldására hivatkozik. Mittwoch szerint (50a-c) azért problematikus, mert az időhatározó egy határozott intervallumot jelöl meg, és ezzel mintegy előre meghatározza a progresszív esemény terjedelmét, ami nem kívánatos. Kearns ezzel vitatkozva amellett érvel, hogy az időhatározó a referenciaidőt módosítja, nem a progresszív eseményt, így az (50a) mondat jólformált lesz, ami egyezik az intuíciónkkal, hiszen jónak ítéltük, Mittwoch alapján azonban rossznak kellene lennie. Meg kell azonban jegyezni itt is, hogy (50a) a continuous igealak ellenére nem tekintendő progresszívnek, de Kearns nem különbözteti meg a kettöt.

${ }^{29}$ Az (50c) esetében a Parsons $(1989,1990)$ által a progresszív teljesítményigék problémájára adott megoldásra támaszkodik (lásd „,befejezetlen objektumok”), de ezt itt nem tárgyalom részletesen.
} 
A fenti példákban az időmódosító (egy pillanat alatt vagy pillanatig) és a mellékmondat (amikor villámlott vagy amikor megérkeztem) egyformán rövid intervallumot jelöl, vagyis nincs köztük terjedelembeli ellentét. A mondatok azonban rosszulformáltak, vagyis az összeférhetetlenség még mindig fennáll, amiből az következik, hogy a rosszulformáltság oka nem a két összetevő által jelölt intervallumok közötti terjedelembeli különbség. Ez viszont Kiefer megállapításának is ellentmond, és azt mutatja, hogy sem Kiefer, sem Kearns magyarázata nem kielégítő.

A következő fejezetekben megmutatom, hogy a különböző típusú időhatározóknak - attól függően, hogy időmódosítóról van-e szó vagy nem - kötött helyük van a felszíni szerkezetben; a két típus által elfoglalt hely természetesen nem azonos. A felszíni szerkezetben elfoglalt helyük meghatározott szemantikai szerepet is maga után von, aminek segítségével megmagyarázható lesz a bemutatott megszorítás.

\subsubsection{Az időmódosítók szintaktikai és szemantikai viselkedése}

A szakirodalomban az eseményekkel kapcsolatban túlnyomórészt azon típusú időhatározókat vizsgálják, amelyeket Vendler (1957) is alkalmazott a különböző igetípusok megállapításához (in, for prepozíciós időhatározók) az (52a-d) alatt látható módon.

52. a) Aurél délben/fél óra alatt/*fél órán át fölmászott a hegyre. (teljesítmény)

b) Aurél délben/fél órán át/*fél óra alatt futott. (cselekvés)

c) *Aurél délben/*fél órán át/*fél óra alatt utálja a történelmet. (állapot)

d) Aurél délben/fél óra alatt/*fél órán át elérte a hegycsúcsot. (eredmény)

(52a-b) esetében a fél óra alatt, valamint fél órán át időhatározó az események kumulatív szakaszára, (52d) mondatban a fél óra alatt az esemény felkészítő szakaszára, 
a délben pedig az esemény kulminációs pontjára vonatkozik. Az (52) példasorban az időmódosítók ige előtti pozícióban állnak, bár egyes beszélők szerint előfordulhatnak a mondatban máshol is (lásd (53a-e)).

53. a) ?? Aurél fölmászott a hegyre fél óra alatt.

b) ?? Aurél fölmászott fél óra alatt a hegyre.

c) ? Fél óra alatt Aurél fölmászott a hegyre.

d) ?? Aurél elérte a hegycsúcsot fél óra alatt.

e) ?? Aurél elérte fél óra alatt a hegycsúcsot.

Mivel azonban semleges intonáció mellett az (53a-e) mondatok elfogadhatósága vitatható, a továbbiakban csak a standard szórendi változatot (lásd 52a-d) vizsgálom.

Az alábbi példapár az időmódosítók tipikus helyét szemlélteti az ige elötti tartományon belül.

54. a) Aurél fél óra alatt lenyirta a füvet.

b) Aurél fél órán át MEZÍTLÁB futott.

Az (54a) mondatban az igekötő közvetlenül az ige előtti pozícióban van, ami azt mutatja, hogy az időmódosító megelőzi az igemódosító/fókusz pozíciót. Ezt alátámasztja (54b), ahol a mondat fókuszt is tartalmaz. Az (52a-d) és (54a-b) példák alapján az időmódosító mindenképp valamilyen ige elötti pozícióban van, de nem állhat topik pozícióban, amit (53c) mutat. ${ }^{30}$ É. Kiss (1992) alapján a magyar mondat felszíni szerkezetének ige előtti tartománya a következőképp épül fel balról jobbra haladva: tetszőleges számú és sorrendủ topik, kvantorok (sorrendjük nem tetszőleges), és végül az

\footnotetext{
${ }^{30} \mathrm{Az}(53 \mathrm{c})$ mondat először talán jólformáltnak tűnik, de vessük össze (52a)-val:

52a) Délben Aurél fölmászott a hegyre.

53c) Fél óra alatt Aurél fölmászott a hegyre.
}

Megmutatkozik a különbség, ha a két mondatot a Mit csinált Aurél ekkor meg ekkor kérdésre akarjuk válaszként adni, amivel a diskurzus topik tesztelhető. Nemcsak hogy válaszként nem megfelelő (53c), de már a kérdés sem jólformált: Mit csinált Aurél fél óra alatt? (Kivéve, amikor a kérdés 'Mit csinált Aurél ezalatt a fél óra alatt?' jelentésben értendö, amikor azonban a fél óra alatt időhatározó más funkciót tölt be a mondatban: nem az esemény hosszának megjelölését, hanem az esemény elhelyezését az időskálán az adott félórányi szakaszon belülre, tehát referenciális.) 
igemódosító vagy fókusz, ami az igét közvetlenül megelőző pozíció. Ez alapján megállapítható, hogy az időmódosítók a kvantormezőben foglalnak helyet. Ebben a mezőben többféle kvantor állhat. Meg tudjuk határozni, hogy milyen kvantornak felelnek meg az időmódosítók, ha az eddigi fél óra alatt, fél órán át kifejezéseket „beszédesebb” időmódosítóval helyettesítjük:

55. a) Aurél rövid idö alatt elérte a hegycsúcsot.

b) \# Aurél hosszú idö alatt elérte a hegycsúcsot.

c) Aurél rövid idö alatt lenyírta a füvet.

d) \# Aurél hosszú idö alatt lenyírta a füvet.

e) Aurél RÖVID IDÖ ALATT nyírta le a füvet.

f) Aurél HOSSZÚ IDÖ ALATT nyírta le a füvet.

Az (55a-b) és (55c-d) példapárok, amelyekben az időmódosítók nem fókusz szerepüek, azt mutatják, hogy az időmódosító által elfoglalt pozíció egyik tulajdonsága, hogy érzékeny az őt kitöltő elem polaritására. Ez nem ismeretlen jelenség, elég, ha a disztributív kvantorokra (mindenki), kirekesztő értelmü kifejezésekre (ritkán, kevesen), pozitív értelmű kvantorokra (is, sok) gondolunk (É. Kiss (1998) példái: 55-56. oldal, (83) és (86)):

56. a) János SOKSZOR/RITKÁN hívja meg Marit vacsorára.

b) János sokszor elkésik az iskolából.

c) *János ritkán elkésik az iskolából.

É. Kiss (1998) részletesen elemzi a különböző fajtájú kvantorokat, és számos alcsoportjukat adja meg. Az (55a-f) példamondatok alapján ezek az időmódosítók mivel állhatnak fókuszban is - a gyakoriság, fok-, mérték- és módhatározók csoportjával mutatnak hasonlóságot, azok közül is a pozitív értelműekkel (lásd (56a-b), illetve (56c)). A gyakoriság, fok-, mérték- és módhatározók a mondat felszíni szerkezetében a kvantormezőben foglalnak helyet, vagyis a topik(ok) és az igemódosító/fókusz között. 
Az (54-56)-os példák segítségével megállapítható szintaktikai pozíció alapján - ami a kvantormező - azt várjuk, hogy szemantikailag az időmódosítók a mondat predikatív részéhez tartoznak. Ha helyes ez a megállapítás, akkor a mondaton elvégzett predikátumtagadás eredménye is megjósolható. Megismétlem a korábbi, (54a) mondatot:

57. a) Aurél fél óra alatt lenyirta a füvet.

b) Aurél nem nyirta le a füvet fél óra alatt. (...Sokkal több idö kellett neki./ \#...Helyette inkább megmetszette az almafát.)

A tagadó mondat azt jelenti, hogy az esemény nem ment végbe az adott idő alatt, magának az eseménynek a végbemenetelét azonban nem tagadja. Mivel a tagadás érintetlenül hagyja az előfeltevéseket, ez arra utal, hogy maga az esemény, a fü lenyírása előfeltevésként van jelen, a fö predikátum a mondatban a tagadott összetevő, vagyis a fél óra alatt időmódosító. Ezt megerősíti az is, hogy a zárójelbe tett folytatási variációknak különböző a megítélése. Az első esetben, ahol az időmódosítóra - mint tagadott összetevőre - kínálunk alternatívát, a folytatás kifogástalan. Ezzel szemben a második eset, amelyben az eseményre kínálunk alternatívát, szerencsétlen. Ez a különbség arra utal, hogy az időmódosító szemantikai viselkedése megfelel a megállapított szintaktikai pozíció alapján elvártnak. Vagyis megállapíthatjuk, hogy az időmódosítók szintaktikailag és szemantikailag a mondat predikátumához tartoznak.

\subsubsection{Az időpontot vagy időintervallumot jelölő időhatározók szintaktikai és szemantikai viselkedése}

Ebben a fejezetben amellett érvelek, hogy az időpontot vagy intervallumot jelölő időhatározót nem indokolt az időmódosítók közé sorolni, ahogy Kiefer (2006) tette, mert szintaktikai és szemantikai jellemzői eltérnek az előzőekben vizsgált, a kvantormezőben megjelenő időmódosítókéitól. Az előző fejezetben láttuk, hogy a vendleri osztályozás 
egyik csoportjába tartozó igék, az eredményigék mellett csak időpontot vagy intervallumot jelölő időhatározó (például délben) állhat a mondatban (lásd (52d)). A példát az alábbi példasorban megismétlem; továbbra is semleges intonációt feltételezek (lásd (58a-d)):

58. a) Aurél délben elérte a hegycsúcsot.

b) Aurél délben lenyirta a füvet

c) Aurél délben megirta a levelet.

d) Aurél délben futott.

Ha az időmódosítók meghatározása az, hogy a leírt esemény egy-egy részeseményét módosítják (Kiefer 2006), akkor az alapján, hogy ő az időpontjelölő időhatározót is időmódosítónak tartja, (58a-d) esetében is meg kell tudnunk határozni, hogy a délben mely részeseményekre vonatkozik. A fenti példákban már nem csak eredményigék szerepelnek. De az, hogy az eredményigék csak az ilyen típusú időmódosítóval kompatibilisek, természetesen nem zárja ki, hogy azok más igecsoport mellett is megjelenhessenek.

(58a) esetében egy pontszerü eseményről van szó, amelynek két részeseménye van: egy felkészítő intervallum és a telikus pont. Ahogy azt már korábban is megállapítottuk, itt az időmódosító az esemény telikus (kulminációs) pontjára vonatkozik. (58d) esetében cselekvésige szerepel a mondatban, Kiefer (2006) szerint az ilyen típusú igéknek egyetlen részeseményük van (lásd 217. oldal, b) pont), egy kumulatív szakasz, és nincs telikus pontjuk. A mondat úgy értelmezhető, hogy az időhatározó az esemény kezdetére vonatkozik (lásd Kiefer (2006) 207. old. 3. lábj.). ${ }^{31}$

$\mathrm{Az}$ (58b-c) mondatban teljesítményigék szerepelnek, amelyek két részeseményből állnak: egy kumulatív szakaszból és egy telikus pontból. Az időhatározó értelmezése azonban bizonytalan. Mindkét mondat perfektív aspektusú, vagyis a benne leírt eseményt a belső szerkezetére való tekintet nélkül, osztatlan egységként tekintjük. (58c) esetében egy feltehetően rövid eseményre gondolunk, ami teljes egészében

\footnotetext{
${ }^{31}$ A mondat természetesen értelmezhető progresszívként is, de azt az esetet később részletesen vizsgálom.
} 
végbemehet a déllel leírt időintervallumban, ezért könnyen értelmezhetjük a mondatot úgy, hogy az időhatározó az oszthatatlan egységnek tekintett teljes eseményre vonatkozik, és mivel az esemény csak a telikus pont elérésével valósul meg, ez egyúttal a megvalósulás pillanatát, a telikus pontot is magában foglalja. (58b) azonban egy feltehetőleg jóval hosszabb ideig tartó eseményt ír le, ezért nehéz figyelmen kívül hagyni a belső szerkezetét egy viszonylag rövid intervallumot jelölő időhatározó mellett, mivel a teljes esemény nem mehet végbe ilyen rövid idő alatt. Óhatatlanul feltételezünk hát egy a telikus ponttól elkülönülő kezdőpontot, mert - az előző példával ellentétben - a két pont közötti különbség itt relevánsnak tünik. A mondatot csak úgy tudjuk értelmezni, ha az időhatározót az esemény kezdetére vonatkoztatjuk. Az (58b) és (58c) értékelése közti különbséget azonban a világtudásunk okozza, vagyis nem nyelvi eredetü, ezért a továbbiakban nem tulajdonítok jelentőséget a köztük lévő különbségnek.

Kiefer (2006) szerint a cselekvésigék (lásd (58d)) és a teljesítményigék (lásd (58b-c)) esetében nincs az eseményeknek olyan részeseménye, amelyről az időpontjelölő időmódosító állítást tehet (szerinte ez a kezdőpont lenne), ezért ez a fajta időmódosító csak az eredményigékkel (lásd (58a)) fér össze. Ez a megállapítás azonban vitatható. Egyrészt azért, mert a kérdéses mondatok teljesen jólformáltak, (58b) esetében pedig ráadásul az esemény kezdőpontjára vonatkoztatjuk az időhatározót. Másrészt azért, mert ha az időpontjelölő időhatározót időmódosítóként kezeljük, akkor többszörösen kivételes viselkedésére kell hagyatkoznunk.

Kiefer álláspontjából egyrészt az következne, hogy az időpontjelölö időhatározó eredményigék mellett időmódosító szerepet tölt be, más típusú igék mellett viszont nem. Másodszor kivételt képezne abból a szempontból is, hogy a többi időmódosítótól eltérően - amelyek egy időtartammal kapcsolatos viszonyt jelölnek (fél óra alatt, két órán belül, egy órán át stb.) - ez az időmódosító a kérdéses részeseményt az időpillanatok lineárisan rendezett halmazához képest helyezi el (lásd Smith (1991): locating adverbs 137. oldal). Harmadszor abból a szempontból is kivétel lenne, hogy a progresszívvel jólformált mondatot alkot, miközben széles körben elfogadott nézet szerint a progresszív aspektus nem fér meg időmódosítókkal, amit a 3.3.1. és 3.3.2. fejezetben már tárgyaltam (lásd (47a) és (48a)) Ha tehát az időpontjelölő időhatározót 
időmódosítóként kezeljük, számos problémába ütközünk, ezért indokolt más szerepet tulajdonítani neki.

Az előzőekben bemutattam, hogy az időmódosítók a kvantormezőben jelennek meg, és a mondat fó predikátumához tartoznak (fókuszt nem tartalmazó mondatokban). Nézzük meg, hogy az időpontjelölő időhatározó hol jelenhet meg a mondatban, és milyen szerepet tölt be szemantikailag!

59. a) Tegnap délben Olívia meglocsolta a kaktuszt.

b) Olivia tegnap délben meglocsolta a kaktuszt.

c) Olívia meglocsolta a kaktuszt tegnap délben.

d) Tegnap délben Aurél épp utazott hazafelé.

e) Aurél tegnap délben épp utazott hazafelé.

f) Aurél épp utazott hazafelé tegnap délben.

Az (59a-c) mondatok ugyan perfektívek, (59d-f) mondatok pedig progresszívek, de a közöttük lévő aspektuális különbség nem befolyásolja az időhatározó megjelenési helyeit, mindkét esetben ugyanazt a mintázatot mutatják. Mind ige előtti (lásd (59a-b) és (59d-e)), mind ige utáni (lásd (59c) és (59f)) pozícióban állhat az időhatározó. Az igekötő ige előtti megjelenése (59a-c)-ben jelzi, hogy a mondatok nem tartalmaznak fókuszt. Azt, hogy az igemódosítókkal ellentétben a tegnap délben időhatározó nem kvantorpozícióban áll, az mutatja, hogy mind az alanyi topik elött, mind mögötte megjelenhet, vagyis a névszói topikkal felcserélhető, tetszőleges sorrendben állnak. Ez a viselkedés egyértelmủen arra utal, hogy az időhatározó topik pozícióban foglal helyet. Kérdés, hogy szemantikailag indokolt-e topiknak tekinteni az időpontjelölő időhatározót.

A mondatok információs szerkezete alapján kétféle ítélettípust különböztetünk meg: a kategorikus és a thetikus ítéleteket, amelyek közül az első topik - komment (logikai alany - logikai predikátum) tagolású, a második topik (logikai alany) nélküli, teljes egészében egy predikátum (Lambrecht (1994)). A topik terminus sokrétü használata (például szintaktikai, pragmatikai) és a topik és a logikai alany terminus 
összemosódása azonban gyakran nehézzé teszi a kategorikus és thetikus kategóriák értelmezését.

Maleczki (2004) a magyarra vonatkozóan a thetikus állítások közös szintaktikai jegyeként elismeri, hogy a szintaktikai topik pozíciója kitöltetlen, ugyanakkor amellett érvel, hogy ezek az állítások nem analizálhatatlan egységek, hanem van belső szerkezetük. Fö érve az, hogy ha a teljes mondat egyetlen predikátum lenne, akkor nem lenne rendelhető hozzá igazságérték. Mivel azonban a thetikus ítéleteknek van eldönthető igazságértékük, valamire vonatkoznia kell az állításnak. A thetikus ítéleteket kifejező mondatok elhangozhatnak mindenféle előfeltevés nélkül, mert adhatók válaszként a Mi történt?, Mi újság? kérdésekre, továbbá mindig valamilyen szituációban hangoznak el, ezért maga a szituáció tekinthető logikai alanynak. Maleczki (2004) szerint tehát a szituációról teszünk velük állítást, amit az alábbi mondatok szemléltetnek. (Maleczki (2004) példái: (26), (16)):

\section{Megérkezett Amanda \\ 61. Egy ismeretlen álldogál a kapuban. ${ }^{32}$}

A topik és a logikai alany megkülönböztetését hangsúlyozza Gécseg (2006) is, aki a két terminust a mondatelemzés különböző szintjeihez tartozónak tekinti. A szövegkörnyezettől független logikai relációk szintjéhez tartozik a logikai alany meghatározása, míg a topiké a szövegkörnyezettől függő, pragmatikai szinthez. A két terminus kapcsolatának az alapja az, hogy mindkettőt az 'aboutness' fogalommal írjuk le, vagyis mindkettő esetében elmondható, hogy valamelyik szinten róla szól a mondatban kifejezett állítás. Gécseg szerint a topik referensének ezen kívül a diskurzusba előzőleg bevezetettnek kell lennie, ami azt jelenti, hogy rá vonatkozó kérdéssel azonosítani lehet. Az alábbi kérdések eltérő jólformáltsága mutatja, hogy melyik összetevő lehet topik (Gécseg (2006) példái, 163. oldal: (51a), (51c), (51f)).

\footnotetext{
${ }^{32}$ Maleczki (2004) bizonyos grammatikai jegyek alapján ezen belül megkülönbözteti a szituáció, illetve esemény logikai alanyú thetikus állításokat, de a dolgozat tárgyát tekintve a további részletek nem relevánsak.
} 
62. a) Mit csinál Mari?

\section{b) ??Mit csinál három gyerek? \\ c) \#Mit csinál valaki?}

Míg a (62a) kérdés tökéletes, és ennek megfelelően a válaszban Mari topik lesz, (62b) jólformáltsága kérdéses, mert olyan referensről kérdezünk, amely nincs előzőleg bevezetve a diskurzusba. A (62c) rosszulformáltságának az oka pedig az, hogy egyértelmüen ismeretlen, azonosíthatatlan referensről szól. A topik így meghatározott fogalma (a diskurzus topik) alapján különböztethetjük meg a thetikus és kategorikus állításokat.

\section{Tegnap délben (épp) futottam.}

A (63)-beli mondat a következő kérdésre adható válaszként: Mit csináltál tegnap délben? A kérdéssel bevezettünk a diskurzusba egy időpontot (tegnap délben), a válasz erre az időpontra utal. A (63)-beli mondat tehát egy egyértelmüen azonosítható, a diskurzusban ismert időpontról tesz állítást, megfelelve a diskurzus topik fogalmának. ${ }^{33}$

A progresszív mondatokban a megjelenő időpontjelölő időhatározó tehát mind szintaktikailag, mind szemantikailag a többi időmódosítótól eltérően viselkedik, ezért Kieferrel ellentétben én nem tekintem időmódosítónak. Az időhatározókon belüli két csoport megkülönböztetését szintén indokoltnak tartja Dowty (1979), mert a logikai nyelv szintaxisában más-más típuskódot rendel hozzájuk. ${ }^{34}$ Mivel a felszíni szerkezetben elfoglalt helye és a diskurzusban betöltött szerepe alapján tehát az időpontjelölő időhatározó topiknak tekinthető, temporális topiknak nevezem.

\footnotetext{
${ }^{33}$ Érdemes azonban megjegyezni, hogy az alábbi kérdés - válasz pár esetében az Aurél éppen annyira diskurzus topik, mint a tegnap délben időhatározó.

i) Mit csinált Aurél tegnap délben?

ii) Aurél tegnap délben éppen futott.

Lehetséges, hogy az információs szerkezet vizsgálatában érdemes lenne a temporális és a nem temporális szint megkülönböztetésének szükségességét vizsgálni. A kérdést Gécseg Zsuzsa vetette fel a dolgozat első változatának bírálatában.

${ }^{34} \mathrm{Az}$ időmódosítókat IV/IV típusú kifejezéseknek tekinti, mert azok inkább aspektuális operátor jellegüek, a topikként megjelenni tudó időpontjelölő időhatározókat pedig TmAdv (temporális adverbium) típusú kifejezéseknek, mert azok az eseményt az időskálán helyezik el.
} 


\subsubsection{Az időmódosítók problémájának megoldása információs szerkezeti megközelítésben}

A temporális topikot tehát rendes diskurzus topikként kezeljük, mivel a progresszív mondat előfeltételezi a temporális topik által jelölt időintervallum létezését és unicitását, vagyis egyértelműen azonosíthatónak kell lennie egy korábban bevezetett, már ismert időintervallummal, amelyről állítást teszünk. A 3.3.2. fejezetben az (57a-b) példa kapcsán predikátumtagadás segítségével azt állapítottuk meg (itt megismételve a példákat), hogy az időmódosító viszont a mondat predikátum részéhez tartozik, így a mondat fennmaradó részében leírt esemény a mondat előfeltételezett része.

47. a) *Aurél fél óra alatt éppen mászott föl a hegyre.

57. a) Aurél fél óra alatt lenyírta a füvet.

b) Aurél nem nyírta le a füvet fél óra alatt. (...Sokkal több idö kellett neki./ \#...Helyette inkább megmetszette az almafát.)

A (47a) mondat esetében tehát a fél óra alatt időmódosító a mondat fő predikátumához tartozik, a mondat előfeltételezett részét pedig az képezi, hogy Aurél fölmászott a hegyre. Ezzel szemben a progresszív aspektus előzőekben bemutatott szemantikája azt követeli, hogy a progresszívként megjelenő esemény legyen a fő predikátum, amellyel az adott időhatározóval kifejezett időintervallumról - mint temporális topikról - teszünk állítást. A (47a) mondatban megjelenő időmódosító és a progresszív esemény tehát egyaránt a mondat fő predikátuma lenne, ami azt jelenti, hogy a topik szerep betöltésére egyiküknek sincs lehetősége. Másik oldalról, mivel mindkettő predikatív szerepü, nincs a mondatban topik szerepü összetevő, ami pedig a kategorikus állításoknál (amilyenek a progresszív mondatok is) kötelező. Ez eredményezi a mondat rosszulformáltságát. 
51. a)*Egy pillanat alatt mászott föl éppen a fára, amikor villámlott.

b) \#Egy pillanatig esett az eső, amikor megérkeztem.

Mivel ez a megoldás nem az időmódosítók durativitására épít, mint Kiefer (2006) vagy Kearns (1991), azt is megmagyarázza, hogy miért rosszulformált az (51a-b) mondat, amelyben pillanatnyi időintervallumot kifejező időmódosító áll (itt megismétlem a példákat). 


\section{A temporális topik jellemzöi}

Az eddigiek alapján elmondható, hogy a progresszív mondatban nem állhat időmódosító, állhat azonban olyan időhatározó (délben), amely bizonyos tekintetben a főnévi topikokhoz hasonlóan viselkedik. ${ }^{35}$ A következőkben a temporális topik néhány további tulajdonságát vizsgálom. Nézzük meg, hogyan azonosítható a temporális topik, és milyen időhatározók tölthetik be ezt a szerepet a progresszív mondatban!

\subsection{Kiterjedés}

Az eddigi példákban szereplő jólformált progresszív mondatokban csak időpontjelölő időhatározó szerepelt, amelyről megmutattam, hogy nem tekintendő időmódosítónak (délben). Ez adja meg a referenciaidőt, amihez képest a progresszív eseményt keretként értelmezzük. A következő példák azt mutatják, hogy a referenciaidőnek - amit most már temporális topiknak nevezek - nem szükséges időpontot jelölnie, jelölhet kiterjedt intervallumot is.

64. Mit csinált márc. 3-án 15.30-kor?

Épp hegyeztem a ceruzámat.

65. Mit csinált márc. 3-án 15.30 és 16.30 között?

a) \# Épp hegyeztem a ceruzámat.

b) Épp futottam.

66. Mit csinált márc. 3-án/tegnap?

\footnotetext{
${ }^{35}$ Az időpont jelölő időhatározót a fentiek értelmében nem sorolom az időmódosítók közé, így a Kiefer által eredetileg használt időmódosító terminus és az itt használt időmódosító terminus e ponttól kezdve eltérő halmazt jelöl.
} 
a) \# Épp hegyeztem a ceruzámat.

b) \# Épp futottam.

c) Épp utaztam hazafelé Kinából.

d) Épp vitorláztam.

A kérdésekkel bevezetjük a diskurzusba a temporális topikot, ami (64) esetében valóban egy időpont, de (65-66) esetében intervallum. A (65a) válasz azért nem fogadható el, mert a megadott időintervallumhoz képest nem tudjuk progresszívként értelmezni az adott eseményt, mivel egy ceruza kihegyezése jellemzően rövidebb ideig tart, mint a temporális topik által jelölt intervallum. Egy tipikusan hosszabb eseményt véve (futás) azonban már elfogadhatóvá válik a mondat ugyanazzal az időhatározóval (lásd 65b). Ugyanezt mutatja (66a-d), még erőteljesebben. Itt jóval hosszabb intervallumot jelöl az időhatározó, így a (65) esetében még megfelelő futás esemény is inkább elfogadhatatlan választ eredményez, hacsak nem extrém sportról van szó. A vitorlázás (lásd 66d) és a Kínából való hazautazás (lásd 66c) eseménye azonban feltehetőleg elég hosszú ideig tart ahhoz, hogy magába foglalja az időhatározó által jelölt időintervallumot, ezért (66c-d) elfogadható. Az egyes válaszok esetében felmerülő megítélésbeli különbségek azonban a világtudásunkkal magyarázhatóak, ezért a temporális topik fogalmát nem korlátozhatjuk a jelölt intervallum terjedelme szerint, mert az ugyanúgy lehet intervallum is, mint ahogy időpont.

$\mathrm{Az}$ intervallumot jelölő időhatározó ugyanakkor nem minden esetben alkot temporális topikot még akkor sem, ha a mondat jólformált. Ezt mutatják az alábbi példák:

67. a) \#Tegnap (épp) locsoltam a kaktuszt.

b) \#Tegnap (épp) másztam föl a fára.

c) Tegnap (épp) locsoltam a kaktuszt, amikor kialudt a villany.

d) Tegnap (épp) másztam föl a fára, amikor eleredt az esö. 
A (67a-b) mondat esetében a zárójeles részt elhagyva ugyan jólformált mondatokat kapunk, de ereszkedő intonációval csak úgy, hogy ha a tegnap időhatározó mindkét esetben fókuszértelmezést kap. Ha progresszív olvasatot tulajdonítunk a mondatoknak, akkor szerencsétlenek, ugyanabból az okból, mint (65-66) esetében az adott időhatározók, vagyis az időhatározók és az események eltérő léptéke miatt. A (67a-b) mondatok azonban tökéletessé tehetők a (67c-d)-ben látható módon. A mondatokhoz kapcsolt mellékmondatok egy-egy időpontot jelölnek, a klasszikus progresszív mondatsémát kapjuk. A mellékmondat által jelölt időpont már alkalmas lehet a referenciaidő szerepre, hiszen a mondatban kifejezett esemény a mellékmondat eseményéhez képest értelmeződik progresszíven. A kérdés ez esetben az, hogy az ilyen mondatokban mi a státusza a tegnap időhatározónak.

Az eddigiekben a jólformált progresszív mondatok mind válaszként voltak adhatók arra a kérdésre, hogy Mit csináltál ekkor meg ekkor? A válaszokban leírt események a kérdésben megadott időpontra vonatkoztatva értelmeződtek progresszíven, vagyis a kérdésben megadott időpont volt a válaszban a referenciaidő, és egyúttal temporális topikként is funkcionált. A Mit csináltál tegnap? kérdésre (67a-b) nem adható válaszként, amire számíthattunk is, hiszen megállapítottuk, hogy a tegnap időhatározó itt nem lehet temporális topik. De ugyanígy nem adható válaszként az egyébként jólformált (67c-d) sem. A (67a-b) mondatokban valóban nincs olyan időintervallum, amelyhez képest progresszívként értelmezhetnénk az adott eseményt, a (67c-d) mondatokban azonban már találhatunk ilyet: ez a mellékmondatban kifejezett események időpontja. Ennek ellenére ezek a mondatok sem megfelelőek válaszként a kérdésre, ami azt mutatja, hogy a tegnap időhatározó ezekben a mondatokban sem temporális topik. Mivel a mellékmondat jelöli meg a referenciaidőt, joggal feltételezhetjük, hogy az általa jelölt időpont lesz a temporális topik. Hogy ezek az időpontok valóban temporális topikok-e, azt az előzőekhez hasonlóan olyan kérdések segítségével tesztelhetjük, amelyekben a vélt temporális topikot megjelöljük. Feltételezésünk alapján a kérdésekre a $(67 \mathrm{c}-\mathrm{d})$ példamondatokat várjuk válaszként: $M i t$ csináltál, amikor kialudt a villany/ eleredt az eső? Várakozásunkkal ellentétben azonban ezekre a kérdésekre sem adhatók válaszként a példamondatok, mert a tegnap 
időhatározó „kilóg” a mondatokból. Ez azt mutatja, hogy annak ellenére, hogy a mellékmondatok által kifejezett időpont adja a progresszív értelmezés alapját, mégsem ez adja a temporális topikot. A (67c-d) mondatok ugyan parafrazálhatóak a következőképpen (lásd (67c'-d')), de a kérdésre nem nyújtanak megfelelő választ, ami azt mutatja, hogy a tegnap időhatározó nem szabad határozóként jelenik meg a mondatban:

67. c’) Amikor kialudt a villany, épp locsoltam a kaktuszt és ez egyébként tegnap volt.

d') Amikor eleredt az eső, épp másztam föl a fára és ez egyébként tegnap volt.

Ahhoz, hogy azonosítsuk a temporális topikot, meg kell találnunk a megfelelő kérdéseket, amelyekre (67c-d) adható válaszként. Ezek a következők: Mit csináltál tegnap, amikor kialudt a villany/ eleredt az eső? Ez egyértelmüen megmutatja, hogy a (67c-d) mondatokban a temporális topikot az időhatározó és a mellékmondat együttesen alkotja annak ellenére, hogy szintaktikailag nem alkotnak egy összetevőt, és más esetekben a mellékmondat és az időhatározó önállóan is lehet temporális topik (lásd (66c-d) és (67c-d)).

\subsection{Az unicitás}

Az előző fejezetekben megállapítottuk, hogy a temporális topik több szempontból közönséges topikként viselkedik. A fönévi topikok jellemzője a magyarban például a specifikusság, azaz a diskurzusban való ismertség, ennek megfelelően a határozott névelős és a specifikus határozatlan névelős főnévi csoportok szoktak topik szerepet betölteni. Mivel a progresszív mondatok referenciaideje temporális topik szerepü, hiszen megfelel az ismertség kritériumának (ezt mutatták az eddigi kérdés-válasz példák), valamint anaforikusan is azonosítható (lásd például 46c), Kearns (1991)-gyel összhangban azt feltételezem, hogy a határozott névelős főnévi csoportokhoz hasonló. 
A határozott névelő jelentésének klasszikusan része az unicitási követelmény. Barwise - Cooper (1981) szerint az a D+N alakú fönévi csoport határozott, amelynek a determinánsa határozott. (Határozottnak tekintik a mutatónévmást tartalmazó főnévi csoportokat is.) Azokat a determinánsokat tekintik határozottnak, amelyek megfelelnek az alábbi definíciónak:

$£ 1$ Egy $D$ determináns határozott, ha minden $M=\langle E,[[]]\rangle$ modellre és minden A-ra, ahol $[[D]](A)$ értelmezve van, van olyan nem üres $B$ halmaz, amelyre $[[D]](A)$ a következö szürö: $\{X \subseteq E \mid B \subseteq X\}$. (Így [[D]](A) az, amit általában A B által generált föszürönek nevezünk. ${ }^{36}$

A határozott névelőt tartalmazó főnévi kifejezés csak ott van értelmezve, ahol a köznév által denotált halmaz egyelemü $(|\mathrm{A}|=1)$, tehát a feltételezésem helyességéhez az kell, hogy a progresszív mondat temporális topikja eleget tegyen az unicitási követelménynek (a pontos definíciót lásd 5.1. fejezet).

68. a) Délben Aurél éppen futott.

b) Akkor Aurél éppen futott.

c) \#Egy/\#Egyik/\#Valamelyik délben Aurél éppen futott.

d) Azokon a napokon Aurél éppen vitorlázott.

e) \#Aurél mindegyik nap/számos alkalommal éppen vitorlázott.

A (68a) példában nincs megjelölve, hogy melyik délről van szó, de vagy az addigi diskurzusból, vagy default módon a beszédszituációból azonosítható a kérdéses nap, vagyis a délben referenciája egyértelmü, egyetlen időintervallumot jelöl. (68b) esetében szintén egyértelmű az időhatározó referenciája, egyetlen intervallumról van szó, amely

\footnotetext{
${ }^{36}$ O.M. fordítása, az eredeti szöveg: ,A determiner $\mathrm{D}$ is definite if for every model $\mathrm{M}=\langle\mathrm{E},[[\mathrm{]}]]\rangle$ and every $A$ for which $[[D]](A)$ is defined, there is a no-empty set $B$, so that $[[D]](A)$ is the sieve $\{X \subseteq E$ | $\mathrm{B} \subseteq \mathrm{X}$ \}. (Hence, $[[\mathrm{D}]](\mathrm{A})$ is what is usually called the principal filter generated by $\mathrm{B}$.)"
} 
az előzetes diskurzusból anaforikusan azonosítható. Ezek az időpontok megfelelnek a határozott névelös főnévi csoportokra jellemző unicitási követelménynek és az ismertség feltételének is. A (68c) példában szereplő időhatározók viszont folytatás nélkül, ereszkedő intonációval rosszulformált mondatot eredményeznek, feltehetően azért, mert a referenciájuk nem egyértelmű, nem minősülnek ismertnek. Ezek a példák megerősítik azt a feltételezést, hogy a progresszív aspektus a temporális topikjától ismertséget követel meg.

Az unicitási követelménynek ugyanakkor ellentmondani látszik a (68d) példa. Itt az ismertség feltétele teljesül, de egyértelmüen több időpontról van szó, vagyis nem teljesül az unicitás feltétele, a mondat mégis jólformált. A (68e) mondatok esetében azonban annak ellenére, hogy az ismertség feltétele teljesülhet adott kontextusban, az unicitás nem biztosított, és a mondatok rosszulformáltak. A kérdés az, hogy mi a különbség a (68d) és (68e) mondatban szereplő időhatározók között, ami megmagyarázza az eltérő ítéleteket. A (68d) típusú mondatok megítélését az alábbi kérdés-válasz párok is alátámasztják, ahol eleve több időpontot jelölünk meg a kérdésekben temporális topik gyanánt, és a válaszok mégis jólformáltak.

69. Hol volt márc. 2-án 8 órakor és 19 órakor?

a) (Azokban az idöpontokban) éppen futottam.

b) (Azokban az idöpontokban) éppen túráztam/másztam föl a hegyre.

70. Hol volt márc. 2-án és márc. 3-án?

a) ?\# (Azokon a napokon) éppen futottam.

b) (Azokon a napokon) éppen vitorláztam.

A (69) alatti kérdésnél az a) választ értelmezhetjük úgy is, hogy egyetlen futás eseményről van szó, vagyis kollektívan, de értelmezhetjük a különböző időpontokra egyenként vonatkoztatva, vagyis disztributívan. Ez utóbbi olvasat azonban több futás eseményt eredményez, amelyek temporális topikjai egyenként teljesítik az unicitás követelményét. (69b) esetében már inkább a kollektív olvasat a preferált, hiszen a 
túrázás és a hegymászás feltehetőleg hosszabb esemény, mint egy „átlagos” futás esemény. A (70) alatti kérdésben nagyobb léptékü időegység szerepel, ezért bizonytalan a (70a) mondat elfogadhatósága az egyetlen, két napot meghaladó (kollektív olvasat), vagy akár két, egy-egy napot meghaladó (disztributív olvasat) futás esemény feltételezése esetén, hacsak nem nyilvánvalóan extrém sporttevékenységről van szó. A (70b) válasz azonban tökéletes, mivel a vitorlázás rendesen tartósabb, jóval nagyobb léptékü tevékenység, mint a futás. Vagyis mindegyik esetben megint csak a világtudásunk játszik szerepet abban, hogy a válasz a kérdésben megjelölt időpontokra egyenként vagy együttesen értendő, de ez nem befolyásolja a többes számú temporális topikkal kapcsolatos unicitási kérdést.

Visszatérve a (68d) és (68e) példák közti különbségre, ahol szintén több időpontról van szó, (68d) esetében az időhatározó a többes számú határozott leírásokhoz hasonló, míg (68e) univerzális kvantort tartalmaz. A főnévi tartományban az a béka határozott névelős főnévi csoport jelentésének része, hogy a köznév által denotált halmaz egyelemü legyen, ezt a feltételt a határozott névelőnek tulajdonítjuk. Az a békák főnévi csoport esetében a köznév többes számú, tehát a békák halmaza nem lehet egyelemü, a határozott névelö azonban továbbra is unicitást követel meg, ami ellentmondáshoz vezet.

Az ellentmondás feloldható, vagyis a határozott névelőnek tulajdonított unicitási követelmény megörizhető, ha a köznevek által denotált halmazokat (például béka) strukturált halmaznak tekintjük (Link (1983)). Ennek megfelelően, ha a modellünk $(\mathrm{M}:=\langle\mathrm{U}, \mathrm{R}\rangle)$ univerzuma $\mathrm{U}$, akkor ezen értelmezünk egy reflexív, tranzitív és antiszimmetrikus részbenrendezési relációt $(\mathrm{R}: \leq)$, amely olyan félháló struktúrát eredményez, amelyen értelmezhetjük az összegképzés müveletét (additív félháló). Ugyanilyen struktúrákat választanak ki ebböl a köznévi denotációk: például ha [[béka $]]=\{$ Locsi, Fröcsi, Breki, Vica $\}$, akkor a félháló elemei a békák halmazának a hatványhalmazának az elemei - amelyek tekinthetők az összegképzés müveletével létrejött többes számú individuumoknak is - az üreshalmazt kivéve (lásd 2. ábra lent). Link az univerzumban az egyes individuumok mellett plurális individuumokat is feltételez, amelyek Landman (1989) alapján a többelemü részhalmazoknak feleltethetök 
meg. Ez alapján az a békák határozott fönévi csoport egyetlen elemét jelöli ki a struktúrának: a maximális elemét, ami magában foglalja a békák halmazának minden elemét $(\{\mathrm{L}, \mathrm{F}, \mathrm{B}, \mathrm{V}\})$.

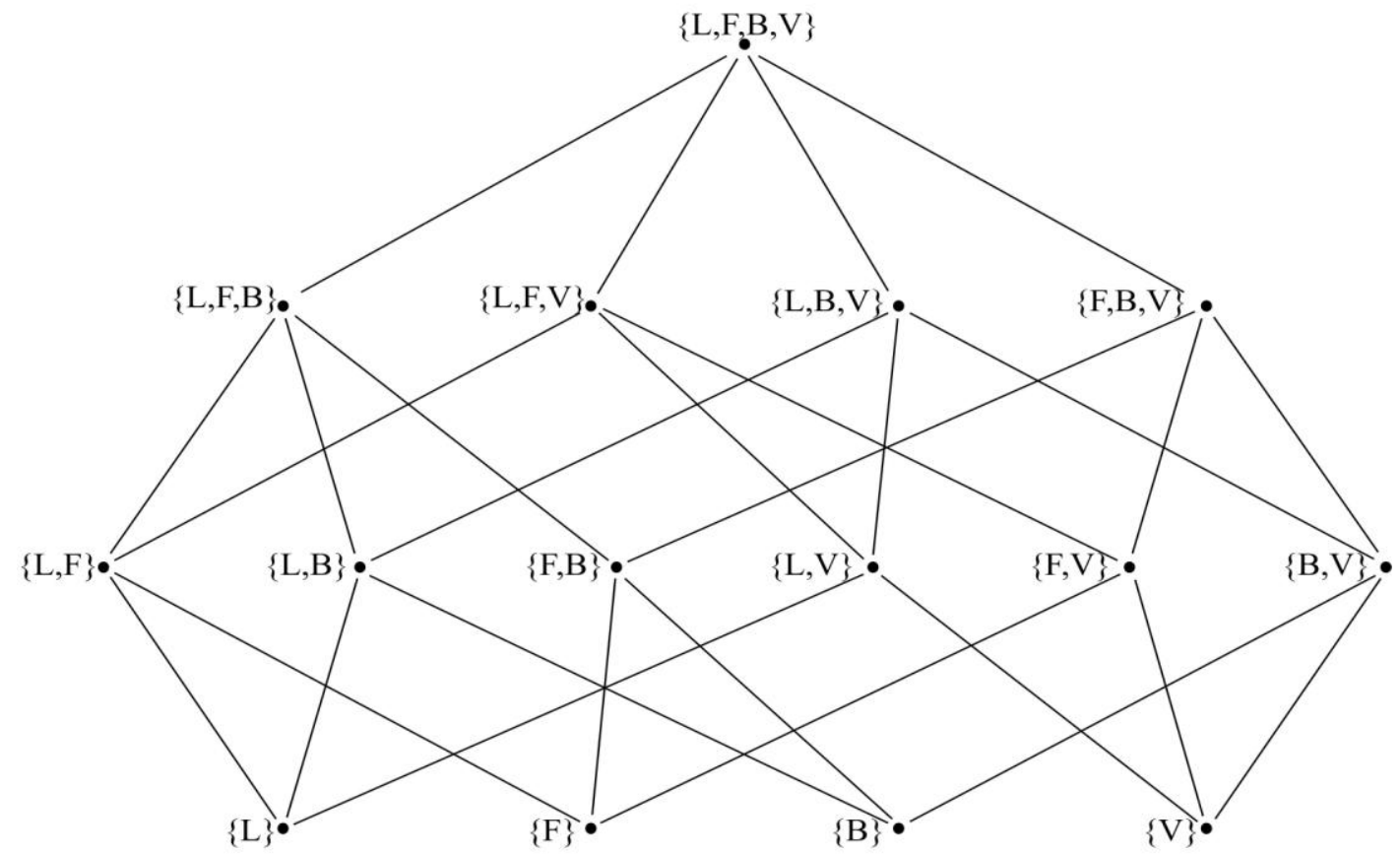

2. ábra

Mivel az a békák főnévi csoport egyetlen - bár többes számú - individuumot jelöl, a háló maximális elemét, amiből csak egy van, az unicitás teljesül. A háló elemeit jelölő többes számú individuumok feltételezésével a határozott névelőnek tulajdonított unicitási követelmény megőrizhető a többes számú határozott leírások esetében is. A határozott névelővel szemben az univerzális determináns viszont nem követeli meg az unicitást a köznév denotációjától, mivel a minden determinánst tartalmazó főnévi csoportok a félháló egészét denotálják, így akár az üreshalmazt is denotálhatják (a Minden béka ugrál állítás igaz, ha az univerzumban nincsenek békák).

Ezek alapján feltételezhetjük, hogy az egyes determinánsok jellemzőinek és a köztük lévő különbségnek az időhatározók esetében is van jelentősége, vagyis a (68) alatti példák megítélése közti különbség tulajdonítható az unicitási feltétel 
teljesülésének. A progresszív aspektusú mondat tehát megköveteli a temporális topikjától az unicitást. Ez azt jelenti, hogy mivel a diskurzusban való ismertség és az unicitás követelménye is jellemző a progresszív mondatokban szereplő temporális topikokra, azok a főnévi tartománybeli határozott főnévi csoportoknak feleltethetők meg a temporális tartományban.

Összefoglalva tehát a progresszív mondatok temporális topikjáról eddig mondottakat, megállapíthatjuk, hogy 1) mindig jelen van, bár nem mindig expliciten, 2) lehet minimális vagy hosszabb intervallum egyaránt, 3) határozott, vagyis teljesíti az ismertség és az unicitás feltételét 4) a felszíni szerkezetben a főnévi topikkal azonos helyeken jelenhet meg, és végül 5) rendes diskurzus topikként viselkedik. Ahogy már jeleztem, a vizsgált tulajdonságok csak szükséges, de nem elégséges feltételei egy progresszív mondat jólformáltságának, az elégséges feltételek megadása nem célom.

\subsection{Glasbey temporális topik intervalluma (TTI)}

A temporális topik terminus nem ismeretlen a szakirodalomban. Sheila Glasbey (Glasbey2005) az angol perfect kapcsán határozza meg a Temporal Topic Interval (TTI) fogalmát. Glasbey egyrészt McCoard (1978) kiterjesztett jelen terminusára (extended now), másrészt Portner (2003) megközelítésére épít, amely a topik szerepét emeli ki a perfect mondatokban. McCoard szerint a perfect igeidő a leírt eseményt egy időintervallumban helyezi el, ez az intervallum a kiterjesztett jelen, ami a múltban kezdődik, és a beszédidővel végződik, vagyis átfogja a reichenbachi eseményidőt (ET) és beszédidőt (ST) (Glasbey (2005) példái: (1),(2),(7)).

71. a) John has arrived today.

John aux-JELEN-E/3 megérkezik-V3 ma

'Ma megérkezett John.' 

b) *John has
arrived
yesterday.

John aux-JELEN-SG3 megérkezik-V3 tegnap

'Tegnap megérkezett John.'

c) John had arrived yesterday.

John aux-MÚLT megérkezik-V3 tegnap

'Tegnap megérkezett John.'

d) John had arrived at $3 p m$.

John auX-MÚLT megérkezik-V3 ELÖLJ-kor. 3.00 du

'Háromkor megérkezett John.'

Glasbey szerint a kiterjesztett jelen fogalmával megmagyarázhatóak a (71a-c) példák. (71a) azért jólformált, mert a kiterjesztett jelent a today ('ma') határozó adja meg, ami valóban magába foglalja az eseményidőt és a beszédidőt. (71b) esetében a yesterday ('tegnap') határozó jelöli a kiterjesztett jelent, ami nem teljesíti azt az elvárást, hogy a beszédidőt magába foglalja, ezért rosszulformált a mondat. (71c) kapcsán Glasbey szerint úgy kell módosítani ezt az elvárást, hogy a kiterjesztett jelennek az eseményidőt és a referenciaidőt (RT) kell magába foglalnia, nem az eseményidőt és a beszédidőt. Ez utóbbi változat tulajdonképpen egy kevésbé megszorított, általánosabb megfogalmazása az elöbbinek, és automatikusan teljesül a jelen idejü mondatban is, hiszen ott a beszédidő megegyezik a referenciaidővel. Glasbey ezen a ponton vezeti be a Temporal Topic Interval (TTI) terminust, mint ami a kiterjesztett jelen fogalmának átnevezése. Ezt a lépést a (71d) mondattal indokolja, amely jólformált, és amelyben az at 3pm ('háromkor') időhatározó nem időintervallumot, hanem időpontot jelöl, így nem szerencsés rá az eddigi kiterjesztett jelen elnevezés. További érve a TTI mellett, hogy a mondatokkal tulajdonképpen ezekről az intervallumokról teszünk állítást, tehát a TTI diskurzus topikhoz hasonló szerepü. Ezt a következő mondattal példázza (Glasbey (2005), 27. példa): 
72. Has

Mary read Middlemarch?

AUX-JELEN-E/3. Mary olvas-V3 Middlemarch

' Olvasta Mary a Middlemarchot?'

Glasbey szerint a fenti mondatnak több olvasata létezik attól függően, hogy mivel azonosítjuk a TTI-t. Az egyik olvasat esetében arra kérdezünk rá, hogy valaha olvasta-e a könyvet Mary, vagyis Mary egész életére. A másik olvasat szerint egy, a diskurzusban „kiemelkedő” (salient) időintervallumra vonatkozik a kérdés. Az előbbi olvasatot szokták egzisztenciális olvasatnak hívni, az utóbbit 'current relevance' olvasatnak. ${ }^{37}$ Utóbbi esetben lehet a kérdésre adott válasz negatív úgy is, ha egyébként korábban már olvasta Mary a könyvet. Glasbey szerint ez azt mutatja, hogy a TTI a diskurzusban előzőleg adott, vagyis tényleg topik. Azt is kimondja, hogy a perfect használata mindig feltételez egy TTI-t, legyen az expliciten kifejezett, vagy csak impliciten, a diskurzusból azonosítható.

A következőkben olyan mondatokat vizsgál, amelyeknél a TTI implicit marad és a mondatok megítélése egyéb tényezőkön múlik (Glasbey (2005) példái: (10), (14-15), (22), (21)).

73. a) \# Einstein has visited Princeton.

Einstein AUX-JELEN-E/3 ellátogat-V3 Princeton

'Einstein járt már Princetonban.'

b) - Which Nobel Laureates have visited Princeton?

- Let's see...Einstein has...

' - Milyen Nobel-díjasok jártak Princetonban?

- Lássuk csak... Einstein járt...'

74. a) What important discoveries have been made in the last1000years? Mi fontos felfedezés-TSZAUX van-V3 csinál-PASSIVEELÖLJ-ben a múlt 1000év-TSZ

\footnotetext{
${ }^{37}$ Az angol present perfectnek még több fajtáját különböztetik meg (lásd Kearns (1991), 208. oldal)
} 
'Milyen fontos felfedezéseket tettek az elmúlt ezer évben?'

b) \# Gutenberghas discovered the art of printing.

Gutenberg AUX-E/3 felfedez-V3 a tudomány ELÖLJ-GEN nyomtatás

'Gutenberg feltalálta a könyvnyomtatást.'

A (73a) és (74b) esetében egzisztenciális olvasattal van dolgunk, és a mondatok rosszulformáltak. Glasbey ezt azzal magyarázza, hogy a TTI (valaha) valójában a (72) mondatban is Mary életét jelenti, pontosabban annak is azt a szakaszát, amelyikben már tudott olvasni, és ez tart a jelenben. ((72) esetében feltételezzük, hogy Mary még most is él.) Vagyis (73a) és (74b) mondatok rosszulformáltsága azzal magyarázható, hogy az alanyaik már nem élnek. (73b) megítélése nem egyértelmü, bár általában elfogadott. Portner (2003) magyarázata szerint nem az alanynak, hanem a topiknak a léte számít a TTI meghatározásában. Mivel (73b)-ben Princeton a diskurzus topikja, és még létezik, a mondat jólformált annak ellenére, hogy Einstein a mondat alanya, és ő már nem él. A (73a) és (74b) mondatokban Einstein és Gutenberg nemcsak alanyok, hanem egyben topikok is, és mivel már nem élnek, a mondatok rosszulformáltak. Glasbey rámutat, hogy Portner megoldása szerint (74b)-nek jólformáltnak kellene lennie abban az esetben, ha úgy tekintjük, mint (74a)-ban szereplö kérdésre adott válasz. Mivel azonban (74b) mindenképp rosszulformált, Portner megoldása nem megfelelő. Glasbey megoldása az, hogy minden, a mondatban szereplö entitás (constituent entities) léte számít a TTI megadásában, nem csak az alanyé vagy a topiké.

Glasbey tehát azt mondja, hogy a present perfect mondatok mindig feltételeznek egy időintervallumot, a TTI-t, ami a kiterjesztett jelen némileg módosított változata. A TTI-nek át kell fognia az eseményidőt és a referenciaidőt, valamint lehet pontszerü is. Ezzel magyarázni tudja az időhatározók viselkedését a jelen idejü mellett a múlt idejü perfect mondatok esetében is. Megállapítja továbbá, hogy a TTI egyben diskurzus topik is, mert a perfect mondattal róla teszünk állítást. A következőkben azt mutatom meg, hogy ez a kijelentés nem állja meg a helyét, vagyis a TTI nem valódi topikja a perfect mondatnak, a temporális topik viszont valódi topikja a progresszív mondatnak. 


\subsection{A TTI topik státusza}

Az alábbi mondatokban explicit TTI, illetve temporális topik (lásd 75-76) szerepel. Ha az itt megjelölt időintervallumok valóban topikok, akkor a diskurzusból már előzőleg ismertnek kell lenniük, ezt biztosítják a kérdések. Glasbey megállapításából következően, miszerint a present perfect mondat a TTI-röl szól, a (75b) válasznak elfogadhatónak kellene lennie.

75. a) Tell me about your day! mond-IMP PRO-E/1 ELÖLJ-ról PRO-GEN nap

'Mesélj a napodról!'

b)\# I have had a large breakfast today. én birtokol-PRES PERF egy nagy reggeli ma 'Nagyot reggeliztem már ma.'

76. a) Mesélj nekem a múlt szombatról!

b) Múlt szombaton épp utaztam hazafelé Japánból.

A fenti példák azt mutatják, hogy a Mi történt ekkor meg ekkor? típusú kérdésre, vagyis ahol az adott időintervallum diskurzus topikként van jelen, perfect igeidejü válasz nem adható. Ez azért különösen érdekes, mert a (75b) mondat egyébként egy jólformált mondat, az időhatározó alapvetően kompatibilis a present perfect igeidővel. Elfogadhatatlansága kizárólag annak tulajdonítható, hogy a kérdés következtében a today 'ma' időhatározónak diskurzus topik szerepet kellene betöltenie.

A present perfect temporális tulajdonságait Kearns is vizsgálja, és a következő példával szemlélteti annak határozatlanságát (Kearns (1991) példái, 176. oldal (6), 212. oldal (41), 182. oldal (15c)): 
77. a) I have been to the market on Monday/*on a Monday/*last Monday. Én van-PRES PERF ELÖLJ-hoz a piac hétfőn/ egy hétfön/ múlt hétfőn 'Voltam már a piacon hétfőn/egy hétfőn/múlt hétfőn.'

b) \# On Monday I have been to the market. ELÖLJ-ön hétfő én van-PRES PERF ELÖLJ-hoz a piac 'Hétfőn voltam már a piacon.'

c) Last year/when I was in Boston John was teaching at Harvard. tavaly/ amikor én van-MÚLTELÖLJ-ban-Boston Johnt anít-MÚLTPROG ELÖLJ-nál Harvard 'Tavaly/ amikor Bostonban voltam, John a Harvardon tanított.'

78. a) Éppen a piacon voltam hétfön délután.

b) Hétfőn délután éppen a piacon voltam.

Kearns rámutat, hogy (77a)-ban a present perfect az on Monday ('hétfőn') időhatározót csak nemspecifikus értelmezéssel engedi meg, mert a nyilvánvalóan specifikus last Monday ('múlt hétfőn') rosszulformálttá teszi a mondatot. Sőt, még a határozatlan névelős időhatározó is, hiszen a mondat ebben az esetben a következőt jelentené: „Egy múltbeli hétfőn létezik olyan időintervallum, amelyre igaz, hogy elmentem a piacra.” Az egyetlen jólformált változat az, amikor az időhatározó puszta köznévként áll. Ez a következőképp írható körül: „Létezik a múltban olyan időintervallum, amelyre igaz, hogy elmentem a piacra és hétfő volt." Más szóval a jólformált mondatban valójában nem piacra menésről van szó, hanem hétfői piacra menésről. Kearns további érve, hogy amennyiben az on Monday időhatározót - amivel egyébként jólformált mondatot alkot a present perfect (lásd (77a)) - kiemeljük topik pozícióba, a mondat szintén rosszulformálttá válik (lásd (77b) ). Ez az érvelés is azt támasztja alá, hogy a present perfect mondatokban megjelenő időhatározó nem lehet topik szerepü. 
Ezzel szemben a (76a-b), (77c) és (78a-b) példákban a progresszív mondatok más eredményt mutatnak. A Mi történt ekkor meg ekkor? típusú kérdésre, ami a diskurzus topik szerepet teszteli előre bevezetett időhatározóval, a progresszív mondat tökéletes válaszként szolgál (lásd (76a-b)). Ennek megfelelően a progresszív azt is megengedi, hogy az időhatározót kiemeljük topik pozícióba (lásd (77c) és (78b)). Mindezek azt mutatják, hogy indokolt a progresszív mondatban megjelenő időhatározót topiknak tekinteni.

A fenti két teszt egyértelmüen mutatja a különbséget a TTI és a temporális topik között. A progresszív mondatokban megjelenő temporális topik valódi diskurzus topik, míg a TTI - temporális topikkal közös tulajdonságai ellenére - nem az. Ezek alapján a progresszív mondatot valóban tekinthetjük olyan kategorikus állításnak, amelyben egy időintervallumról (a topik szerepű referenciaidőről) teszünk állítást. A present perfect mondat viszont nem tartalmazhat időhatározói topikot a Glasbey által meghatározott TTI jelenléte ellenére sem. 


\section{A temporális determináns-függvények felé}

Miután láthattuk, hogy a progresszív mondatokban megjelenő időhatározó viselkedése egyértelműen a főnévi diskurzus topikokéhoz hasonlít, a továbbiakban - az ezt ontológiailag is alátámasztó néhány tanulmány ismertetését követően - a temporális topikokra alkalmazom a főnévi csoportok szemantikai vizsgálatában jól bevált általánosított kvantorok elméletét.

\subsection{Elméleti háttér: az általánosított kvantorok elmélete (Barwise- Cooper (1981))}

A predikátumlogikából ismert univerzális $(\forall)$ és egzisztenciális $(\exists)$ kvantorok korlátozott lehetőséget jelentenek a kvantoros főnévi kifejezéseket tartalmazó mondatok leírásában. Bár a határozott névelős és a minden determinánssal rendelkező főnévi csoporttal, továbbá a határozatlan névelövel rendelkező főnévi csoporttal alkotott mondatokat le tudjuk írni velük, a kapott formulák nem kompozicionálisan épülnek föl. Ezekben az esetekben ugyanis a mondatok egészéhez rendelünk egy olyan formulát, amely visszaadja az adott mondatok igazságfeltételeit, nem pedig a mondatok egyes részkifejezéseihez rendelünk részformulákat, amelyekből összeépül a mondatoknak megfeleltetett formula. (lásd 79-81).

79. Egy béka ugrál.

$$
\exists \mathrm{x}[\mathrm{B}(\mathrm{x}) \wedge \mathrm{U}(\mathrm{x})]
$$

80. Minden béka ugrál.

$$
\forall \mathrm{x}[\mathrm{B}(\mathrm{x}) \rightarrow \mathrm{U}(\mathrm{x})]
$$


81. A béka ugrál.

$\exists \mathrm{x} \forall \mathrm{y}[\mathrm{B}(\mathrm{y}) \leftrightarrow \mathrm{y}=\mathrm{x} \wedge \mathrm{U}(\mathrm{x})]$

82. Legalább három béka ugrál.

$\exists \mathrm{x} \exists \mathrm{y} \exists \mathrm{z}[\mathrm{B}(\mathrm{x}) \wedge \mathrm{B}(\mathrm{y}) \wedge \mathrm{B}(\mathrm{z}) \wedge \mathrm{U}(\mathrm{x}) \wedge \mathrm{U}(\mathrm{y}) \wedge \mathrm{U}(\mathrm{z}) \wedge \mathrm{x} \neq \mathrm{y} \wedge \mathrm{x} \neq \mathrm{z} \wedge \mathrm{y} \neq \mathrm{z}]$

83. Sok/ a legtöbb béka ugrál.

A számnévi kifejezéseket tartalmazó kvantoros főnévi csoportokkal alkotott mondatok leírása már meglehetősen körülményes (lásd (82)), és vannak olyan determinánsokat tartalmazó mondatok, amelyeknek nem tudjuk megadni az igazságfeltételeit a korlátozatlan univerzális és egzisztenciális kvantifikáció segítségével (lásd (83)). Ezeknek a problémáknak a megoldására ad lehetőséget az általánosított kvantorok elmélete (Mostowski (1957), Barwise - Cooper (1981)).

Az általánosított kvantorok elméletében nincsenek elemi kvantorok, mint a predikátumlogikából ismert $\forall$ és $\exists$. Egy kvantor $(Q)$ olyan $\mathrm{D}+\mathrm{N}$ alakú kifejezések fordítása a logikai nyelvben, amelyekben D egy determináns, $\mathrm{N}$ pedig egy köznév, halmazjelölő kifejezés. Ilyen $\mathrm{D}+\mathrm{N}$ alakú kifejezés például a minden béka. Az általánosított kvantorok elméletében tehát a teljes főnévi csoport denotációja a kvantor. Barwise - Cooper (1981) a következőképp adja meg az egyes kifejezések jelöletét (Barwise - Cooper (1981), 168-170. oldal):

SZ1: Ha $\eta$ egy halmazjelölő kifejezés, akkor a jelölete a következőképp adható meg:

$$
[[\eta]] \subseteq \mathrm{U} .
$$

SZ2: Ha P egy n-argumentumú predikátum, akkor a jelölete a következőképp adható meg: 


$$
[[\mathrm{P}]] \subseteq \mathrm{U}^{\mathrm{n}}
$$

SZ3: Ha D egy determináns és $\eta$ egy halmazjelölő kifejezés, akkor $D(\eta)$ egy kvantor, amelynek a jelölete a következőképp adható meg:

$$
[[D(\eta)]]=[[D]]([[(\eta)]])
$$

SZ4: Ha Q = D $(\eta)$ egy kvantor és $\gamma$ egy halmazjelölő kifejezés, akkor Q $\gamma$ jelölete egy igazságérték a következőknek megfelelően:

$$
\begin{array}{r}
{[[\mathrm{Q} \gamma]]=1 \text {, ha }[[\gamma]] \in[[\mathrm{Q}]]} \\
0, \text { ha }[[\gamma]] \notin[[\mathrm{Q}]]
\end{array}
$$

SZ5: Minden predikátum halmazjelölő kifejezés.

Tekintsük az Egy béka kuruttyol példamondatot! SZ1 alapján egy N köznévi kifejezés denotációja az univerzum egy részhalmaza, ami a példamondat esetében a békák halmaza:

$£ 1$

$$
[[b e ́ k a]] \subseteq \mathrm{U}
$$

SZ2 alapján a kuruttyol mint egyargumentumú predikátum jelölete szintén az univerzum egy részhalmaza, amely halmaz a kuruttyoló individuumokat tartalmazza:

\section{$£ 2$}

$$
[[\text { kuruttyol }] \subseteq \mathrm{U}
$$

SZ3 alapján az egy béka főnévi csoport determinánsának interpretációja a modellben egy olyan függvény, amely argumentumként veszi fel a köznév által jelölt halmazt (itt a békák halmaza), és az így létrejött általánosított kvantor nem más, mint a következőképpen definiálható halmazok halmaza:

$$
[[\mathrm{D}]](\eta)=[[\text { egy }]]([[\text { béka }]])=\{\mathrm{X} \subseteq \mathrm{U} \mid[[\text { béka }]] \cap \mathrm{X} \neq \varnothing\} .
$$


SZ4 alapján az egy béka fónévi csoportnak megfeleltetett $\mathrm{Q}=\mathrm{D}(\eta)$ általánosított kvantor tekinthető egy olyan függvénynek, ami argumentumaként veszi fel a predikátum által jelölt $\gamma$ individuumhalmazt (a kuruttyolók halmazát): $(D(\eta))(\gamma)$, és ehhez a kuruttyol tulajdonsághoz (halmazhoz) rendel igazságértéket a következő módon:

$£ 4[[$ egy béka $($ kuruttyol $)]]=1$, ha $[[$ kuruttyol $]] \in[[$ egy béka $]]$, egyéb esetben 0 .

Tehát egy Q általánosított kvantor denotációja megadható individuumhalmazok pontosabban tulajdonságok - halmazaként, mégpedig azon tulajdonságok halmazaként, amelyek a $\mathrm{D}$ és $\mathrm{N}$ által meghatározott individuumokra jellemzőek. Az egy béka főnévi csoportnak megfeleltetett általánosított kvantor denotációja így azon halmazoknak a halmaza, amelyek tartalmaznak legalább egy békát.

$£ 5$

$[[$ egy béka $]]=\{\mathrm{X} \subseteq \mathrm{U} \mid[[$ béka $]] \cap \mathrm{X} \neq \varnothing\}$.

Ilyen módon egységesen megadható a legkülönfélébb determinánsokat tartalmazó főnévi kifejezések, valamint a tulajdonnevek szemantikai értéke is, halmazelméleti alapon. A determináns azonban nemcsak olyan függvényként értelmezhető, amely miután alkalmaztuk egy individuumhalmazra, újabb individuumhalmazt vesz fel argumentumként - jelölése: $(\mathrm{D}(\mathrm{A}))(\mathrm{B})$-, hanem individuumhalmazok közötti relációként is felfogható (jelölése: $\mathrm{D}(\mathrm{A}, \mathrm{B})$ ). Mivel a kétféle értelmezés ekvivalens, és intuitív alapon az aspektusra is relációként szokás utalni, ezért a következőkben ezt a jelölést használom. A determináns relációs megközelítésben tehát két individuumhalmaz, a köznév által jelölt halmaz (a békák halmaza) és a predikátum által jelölt halmaz (a kuruttyolók halmaza) közötti relációként adható meg. A különböző általánosított kvantorok esetében a determinánsok különbözősége miatt természetesen a 
halmazok közötti reláció eltérő. Az alábbiakban az aspektusokkal összefüggésbe hozható determinánsok által meghatározott relációkat ábrázolom Venn-diagramok segítségével.

\section{4. a) Egy béka ugrál.}

b) Néhány béka ugrál.

Az első vizsgált determináns a határozatlan névelő, ami (84a)-ban (lásd korábban (79)) 'legalább egy' jelentésben szerepel. Ez igazságfeltételesen nem különböztethető meg a (84b)-ben szereplő néhány determinánstól, mert mindkét esetben az határozza meg a velük alkotott állítások igazságértékét, hogy a békák és az ugrálók halmazának a metszete üres-e vagy sem. A határozatlan névelőt tartalmazó általánosított kvantor jelöletének (lásd £5) megfelelően tehát a következőképp adható meg a néhány béka kifejezés denotációja általánosított kvantorként:

$£ 5$

$$
[[\text { néhány béka }]]=\{\mathrm{X} \subseteq \mathrm{U} \mid[[\text { béka }]] \cap \mathrm{X} \neq \varnothing\}
$$

A következő ábrán látható reláció szemlélteti a (84a-b) mondatokban megfogalmazott állítások ekvivalens igazságfeltételeit:

$$
\begin{array}{ll}
\mathrm{A}=[[\text { béka }]], & {[[\text { béka }]] \subseteq \mathrm{U}} \\
\mathrm{B}=[[\text { ugrál }]] & {[[\text { ugrál }]] \subseteq \mathrm{U}}
\end{array}
$$

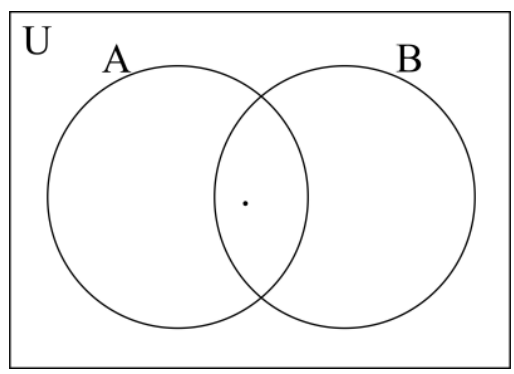

3. ábra 
Nézzük az univerzális determinánst, megismételve a korábbi példát (lásd (80)):

\section{Minden béka ugrál.}

A (85)-ös mondatban az univerzális determinánst tartalmazó minden béka általánosított kvantor jelölete a következőképp adható meg:

$£ 6$

$$
[[\text { minden béka }]]=\{\mathrm{X} \subseteq \mathrm{U} \mid[[\text { béka }]] \subseteq \mathrm{X}\}
$$

A mondatban szereplő predikátumok által jelölt halmazok közötti relációt az 4. ábra szemlélteti:

$$
\begin{array}{ll}
\mathrm{A}=[[\text { béka }]], & {[[\text { béka }]] \subseteq \mathrm{U}} \\
\mathrm{B}=[[\text { ugrál }]] & {[[\text { ugrál }]] \subseteq \mathrm{U}}
\end{array}
$$

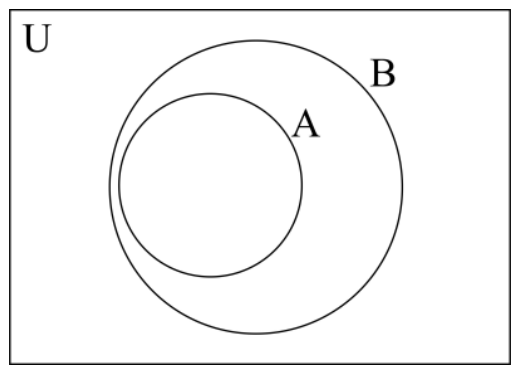

4. ábra

Megismételve a korábbi (81)-es példát, nézzük a határozott névelős általánosított kvantort tartalmazó mondatot:

\section{A béka ugrál.}

A határozott névelöt tartalmazó általánosított kvantor jelölete a következőképp adható meg: 
A következő ábra mutatja a (86) mondatban megfogalmazott állítás igazságfeltételeit.

$$
\begin{array}{ll}
\mathrm{A}=[[\text { béka }]]=\{\mathrm{b}\}, & {[[\text { béka }]] \subseteq \mathrm{U}} \\
\mathrm{B}=[[\text { ugrál }]] & {[[\text { ugrál }]] \subseteq \mathrm{U}}
\end{array}
$$

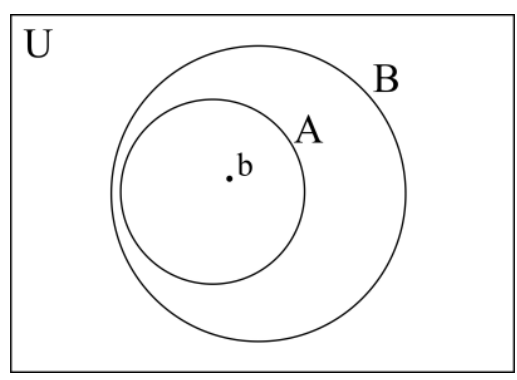

5. ábra

(86) esetében a békák A halmazának számossága kötött, hiszen szigorúan egyelemü halmazról van szó, mert az általánosított kvantorok elmélete a határozott névelőt egyelemü köznévi denotáción értelmezett univerzális kvantifikációnak tekinti. Ahol a köznév által denotált halmaz nem egyelemü, ott nincs értelmezve a határozott névelős fönévi kifejezés.

A the ('a/az') határozott névelö fordítása a logikai nyelvben a the (the 1) ('a/az', vagyis 'az 1') kifejezés, amelynek a szemantikai értéke egy olyan függvény, amelyet az 'az n' általános definíciója alapján adhatunk meg - ahol n tetszőleges természetes szám a következőképp:

$£ 8$

$$
[[\mathrm{a} / \mathrm{az} \mathrm{n}]](\mathrm{A})=[[\text { minden }]](\mathrm{A}) \text { ha }|\mathrm{A}|=1 \text {, egyébként nem definiált }{ }^{38}
$$

$38,[[$ the $n]](A)=[[$ every $]](A)$ if $|A|=1$, undefined otherwise"

(Barwise- Cooper (1981), 169. oldal). 
Az A halmaz egyetlen eleme tehát egyúttal eleme B-nek is, vagyis a békák egyelemü halmaza részhalmaza az ugrálók halmazának.

\subsubsection{Monotonitás}

A monotonitás egy olyan függvénytulajdonság, amelyet a természetes nyelvi determinánsok jellemzésében is használunk, és következtetések érvényességének a vizsgálatával állapítható meg.

$£ 9$

Monotonitás:

Akkor monoton egy D determináns, ha egy D N VP szerkezetü mondatban az $N$ köznév denotációját jelölő A halmaz, vagy a VP denotációját jelölö $B$ halmaz bövitése vagy szükitése nem változtat az adott mondatban megfogalmazott állitás igaz értékén. Az elöbbi esetben növekvő, az utóbbiban csökkenö monotonitású a D.

A monotonitás két oldalról is értelmezhető. Tetszőleges $D(A, B)$ szerkezetủ állítás esetén, ahol A a főnévi kifejezés által denotált halmaz, B pedig az igei kifejezés által denotált halmaz, egy $\mathrm{D}$ determináns bal monoton, ha az általa jelölt függvény az $\mathrm{A}$ halmazra vonatkoztatva monoton, és jobb monoton, ha a B halmazra vonatkoztatva monoton. A természetes nyelvi determinánsok jellemezhetőek tehát aszerint, hogy balról vagy jobbról monotonak-e vagy sem, és ha monotonak, akkor növekvőek-e vagy csökkenőek. $^{39}$

Bal monoton növekvö egy $D$ determináns akkor és csak akkor, ha $[[D]](A, B)=1$ esetén minden $A^{\prime}-r e$, ahol $A \subseteq A^{\prime}:[[D]]\left(A^{\prime}, B\right)=1$

\footnotetext{
${ }^{39}$ Az alábbi definíciók megadásában Gyuris B. - Varasdi K. - Maleczki M. (2008) jelöléstechnikáját használom (139-140. oldal).
} 
Bal monoton csökkenö egy D determináns akkor és csak akkor, ha [[D]] $(A, B)=1$ esetén minden $A^{\prime}-r e$, ahol $A^{\prime} \subseteq A:[[D]]\left(A^{\prime}, B\right)=1$

Jobb monoton növekvö egy $D$ determináns akkor és csak akkor, ha $[[D]](A, B)=1$ esetén minden $B^{\prime}-r e$, ahol $B \subseteq B^{\prime}:[[D]]\left(A, B^{\prime}\right)=1$

Jobb monoton csökkenö egy D determináns akkor és csak akkor, ha $[[D]](A, B)=1$ esetén minden $B^{\prime}-r e$, ahol $B^{\prime} \subseteq B:[[D]]\left(A, B^{\prime}\right)=1$

Nem monoton egy determináns akkor és csak akkor, ha se nem csökkenö, se nem növekvö.

A monotonitási tulajdonságokat az alábbi következtetési sémák mutatják. Először a határozatlan névelőt vizsgáljuk meg. Mivel az egy determináns nemcsak a 'legalább egy', hanem a 'pontosan egy' jelentéssel is bír, a korábbi magyarázat alapján a példamondatokban a néhány determinánst szerepeltetem. A Néhány béka ugrál mondat $\mathrm{D}(\mathrm{A}, \mathrm{B})$ szerkezetü, ahol $\mathrm{D}$ a néhány determináns, A a békák halmaza, $\mathrm{B}$ az ugrálók halmaza. A határozatlan névelő baloldali monotonitására vonatkozó következtetési séma az alábbi (az érintett halmazokat jelölő kifejezéseket vastagon szedem):

M1) $\mathrm{A} \subseteq \mathrm{A}$ ’ Néhány béka ugrál. $\Rightarrow$ Néhány állat ugrál.

M2) A’ $\subseteq$ A: Néhány béka ugrál. * $\Rightarrow$ Néhány kecskebéka ugrál.

Az A halmaz bővítése esetén a jobboldali állítás igazsága logikailag következik a bal oldali állítás igazságából, hiszen ha néhány béka ugrál, akkor - mivel a békák állatok minden esetben igaz, hogy néhány állat ugrál. Az A halmaz bővítése tehát megőrzi a mondattal kifejezett állítás igazságát. Ezzel szemben az A halmaz szúkítésével nem marad meg az állítás igazsága, mert abból, hogy néhány béka ugrál, nem következik, 
Ohogy azok között vannak kecskebékák is; például lehet, hogy az összes ugráló béka varangy. Mivel a jobb oldali mondat igazsága nem következik a bal oldali mondat igazságából az A halmaz szükítése esetén, de a bővítése esetén igen, a néhány determináns balról monoton növekvő. Nézzük meg a jobb oldali monotonitással kapcsolatos következtetéseket:

M3) $\mathrm{B} \subseteq \mathrm{B}$ ': Néhány béka ugrál. $\Rightarrow$ Néhány béka mozog.

M4) B' $\subseteq$ B: Néhány béka ugrál. * $\Rightarrow$ Néhány béka egy helyben ugrál.

Ha néhány béka ugrál, abból következik az, hogy néhány béka mozog. A B halmaz bővítése tehát megőrzi az állítás igazságát: ha (M3)-ban a baloldali mondat igaz, abból logikailag következik a jobb oldali mondat igazsága. Ha azonban szükítjük a B halmazt, a következtetés nem áll, mert könnyen lehet, hogy bár néhány béka ugrál, az ugráló békák mindegyike szanaszét ugrál, és egyik sem ugrál egy helyben. Vagyis (M4)-ben a jobb oldali mondat igazsága nem következik a bal oldaliéból. Ez alapján tehát a néhány determináns jobbról monoton növekvő. Most nézzük az univerzális determinánst!

M5) $\mathrm{A} \subseteq \mathrm{A}$ ': Minden béka ugrál. * $\Rightarrow$ Minden állat ugrál.

M6) A’ $\subseteq$ A: Minden béka ugrál. $\Rightarrow$ Minden kecskebéka ugrál.

A Minden béka ugrál mondat esetében az A halmaz bővítésével az eredeti állítás igazságából nem következik a jobboldali állítás igazsága (lásd (M5)), mert például egy olyan modellben, ahol csak a békák ugrálnak, a nyíl jobb oldalán álló mondat hamis, a minden determináns tehát nem balról monoton növekvő. Ha azonban az $\mathrm{A}$ halmazt szükítjük, a következtetés helyes (lásd (M6)), mert abból, hogy minden béka ugrál, következik, hogy minden kecskebéka ugrál, hiszen a kecskebékák is békák. Mivel a minden determináns definíciójából (lásd £6) következik, hogy ez az A bármely részhalmazára teljesül, a D determináns balról monoton, méghozzá csökkenő. 
M7) $\mathrm{B} \subseteq \mathrm{B}$ : Minden béka ugrál. $\Rightarrow$ Minden béka mozog.

M8) B' $\subseteq$ B: Minden béka ugrál. * $\Rightarrow$ Minden béka egy helyben ugrál.

A B halmaz bővítésével megőrződik a mondat igazsága, ha azonban a $\mathrm{B}$ halmazt szükítjük, a baloldali mondat igazságából nem következik a jobb oldali mondat igazsága (lásd (M8)). Egy olyan modellben, amelyben van olyan béka, amelyik valamilyen irányba haladva ugrál, a jobb oldali mondat hamis. Mivel a B halmaz szükítésével nem mindig őrződik meg az állítás igazsága, a bővítésével azonban igen, a minden univerzális determináns jobbról monoton növekvő. Most nézzük meg a következtetési sémát a határozott névelőt tartalmazó főnévi csoport esetében!

M9) $\mathrm{A} \subseteq \mathrm{A}^{\prime}:$ A béka ugrál. $*$ Az állat ugrál.

M10) A’ $\subseteq$ A: A béka ugrál. * $\Rightarrow$ A kecskebéka ugrál.

Elöször a baloldali monotonitást nézzük! Az A halmaz bővítése következtében megváltozhat az állítás igazsága (lásd (M9)), mert annak, hogy egy bizonyos béka ugrál, nem következménye az, hogy egy bizonyos állat ugrál, hiszen ez az állat nem feltétlenül béka. A határozott névelős főnévi csoport esetében az unicitás feltétele miatt az A halmaznak egyelemünek kell lennie (lásd £8), ezért akár bővíteni, akár szükíteni akarnánk, az unicitás sérülne. Tehát a határozott névelő balról se nem növekvő, se nem csökkenő, vagyis nem monoton. Nézzük a jobboldali monotonitást:

M11) $\mathrm{B} \subseteq \mathrm{B}^{\prime}:$ A béka ugrál. $\Rightarrow$ A béka mozog.

M12) $\mathrm{B}$ ' $\subseteq$ B: A béka ugrál. * $\Rightarrow$ A béka egy helyben ugrál.

A B halmaz bővítése érintetlenül hagyja az állítás igazságát, mert abból, hogy egy bizonyos béka ugrál, következik az, hogy ugyanez a béka mozog (lásd (M11)). Ha azonban a B halmazt szükítjük, a baloldali mondat igazságából nem következik a jobb oldali mondat igazsága (lásd (M12)). Egy olyan modellben, amelyben a mi békánk 
valamelyik irányba haladva ugrál, a jobb oldali mondat hamis. Mivel a B halmaz szükítésével nem mindig őrződik meg az állítás igazsága, a bővítésével azonban igen, ez azt jelenti, hogy a határozott névelő jobbról monoton növekvő determináns.

\subsubsection{A determinánsok általános tulajdonságai}

$\mathrm{Az}$ általánosított kvantorok elméletének segítségével meghatározható általános determinánsi tulajdonságok a kiterjeszthetőség, a konzervativitás és a kvantitás, ezek majdnem minden természetes nyelvi determinánsra jellemzőek. Az alábbiakban azokat a tulajdonságokat ismertetem, amelyeknek a későbbiekben szerepe lesz.

\subsubsection{Kiterjeszthetőség}

Az egyik általános determinánsi tulajdonság a kiterjeszthetőség. Egy $\mathrm{D}$ determináns akkor kiterjeszthető, ha minden U-ra és U'-re, ahol U $\subseteq$ U':

Ez azt jelenti, hogy egy állítás igazságértékének a megállapításában nem játszik szerepet az univerzum nagysága, csak az A és B halmaz. Vegyük a korábbi példamondatainkat.

84.) Egy béka ugrál.

85.) Minden béka ugrál

86.) A béka ugrál.

A kiterjeszthetőség azt mondja tehát, hogy a fenti mondatok igazságának szempontjából csak a békák halmaza és az ugrálók halmaza játszik szerepet. Egy olyan modellben 
például, amelynek az univerzumában csak egyetlen individuum van, és az eleme a békák és az ugrálók halmazának is, a (84-86) mondatok igazak. Az Egy béka ugrál mondat azért, mert a békák és az ugrálók halmazának a metszete nem üres, a Minden béka ugrál mondat azért, mert az univerzumban lévő összes béka individuum eleme az ugrálók halmazának, az A béka ugrál mondat pedig azért, mert az egyetlen béka individuum eleme az ugrálók halmazának.

Ha az univerzumot bővítjük, és mindenféle nem béka individuummal benépesítjük, (84) és (85) igazságértéke akkor sem változik, mert azt nem befolyásolja, hogy például zsiráfok, giliszták és gazok vannak-e az univerzumban. Ráadásul az sem számít, hogy az univerzumnak a békák halmazán kívüli elemei ugrálnak-e, az állítások akkor is igazak maradnak, ha senki más nem ugrál, és akkor is, ha mindenki ugrál. És végül az sem befolyásolja (84) és (85) igazságát, hogy a békák milyen egyéb tevékenységet folytatnak, udvarolnak, brekegnek vagy vadásznak-e az ugráláson kívül. A (86) mondat csak a békák halmazának egyelemüsége esetén értelmezhető (ezt teljesítheti a kontextus is), az univerzumot benépesítő egyéb lények azonban itt sem befolyásolják a mondat igazságát. A fenti mondatok igazságértékét egyedül a békák és az ugrálók halmaza határozza meg. ${ }^{40}$

\subsubsection{Konzervativitás}

A következő általános determinánsi tulajdonság a konzervativitás. Egy D determináns konzervatív, ha teljesül rá a következö:

$$
(\mathrm{D}(\mathrm{A}))(\mathrm{B}) \Leftrightarrow(\mathrm{D}(\mathrm{A}))(\mathrm{A} \cap \mathrm{B})
$$

\footnotetext{
${ }^{40}$ A kiterjeszthetőség nem kivétel nélkül az összes természetes nyelvi determináns jellemzője (lásd

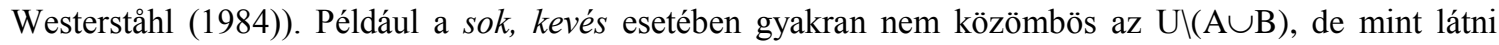
fogjuk, az aspektusokkal kapcsolatba hozható determinánsokra jellemző a kiterjeszthetőség.
} 
Ez azt jelenti, hogy egy (D(A)) általánosított kvantor az általa felvett argumentumnak, vagyis a B halmaznak csak azzal a részével „foglalkozik”, amelyik az A halmaznak is része (azaz csak az $(\mathrm{A} \cap \mathrm{B}) \mathrm{az}$, ami számít az igazságfeltételek meghatározása szempontjából). Az eddigi példáinkat megvizsgálva, a Minden béka ugrál mondat esetében a minden béka által denotált általánosított kvantor egy olyan függvény, ami egy predikátum kifejezés denotátumát veszi föl argumentumként, ami a mi esetünkben az ugrálók halmaza. A mondat igazságértéke szempontjából csak az számít, hogy a békák halmaza (lásd A) teljes egészében része legyen az ugrálók halmazának (lásd B), vagyis minden béka benne legyen az ugrálók halmazában. Az viszont egyáltalán nem számít, hogy a $\mathrm{B}$ halmaznak az $\mathrm{A}$ halmazon kívüli része (lásd $\mathrm{B} \backslash \mathrm{A}$ ) mit tartalmaz, vagy tartalmaz-e egyáltalán valamit. Ugyanígy a Néhány béka ugrál mondat esetében sem számít, hogy az univerzumban a békákon kívül ugrál-e még valaki vagy nem (lásd $B \backslash A$ ), egyedül az számít, hogy a békák halmazának van-e olyan eleme, ami egyúttal eleme az ugrálók halmazának (lásd $\mathrm{A} \cap \mathrm{B})$.

\subsection{A szakirodalmi háttér}

A főnévi és igei (temporális) tartomány között megfigyelhető hasonlóságra számos utalás történt már a szakirodalomban. A témában talán a legismertebbek Barbara Partee, Emmon Bach és Manfred Krifka munkái: Partee (1984) a múlt idő anaforikus jellegét tárgyalja, Bach és Krifka az anyagnevek és megszámlálható főnevek, illetve a cselekményigék és teljesítményigék közötti párhuzamot (Bach 1986, Krifka 1989). Bach (1986) vizsgálja például a progresszív aspektus kapcsán felmerülő imperfektív paradoxonnak a fönévi tartományban való meglétét. Az alábbiakban olyan tanulmányokat ismertetek, amelyek egyrészt az individuumok és időpillanatok közötti ontológiai párhuzamot, másrészt a progresszív aspektus esetében felmerülö határozottságot tárgyalják. Megállapításaikkal alátámasztják a dolgozat fö állítását, miszerint az aspektus tekinthető temporális determinánsnak, valamint a progresszív 
aspektus a mondatban megjelenő időhatározóval együtt temporális általánosított kvantorként interpretálható kifejezést alkot.

\subsubsection{A progresszív aspektus mint határozott igeidő (Kearns 1991)}

Kearns (1991) az angol progresszív aspektust vizsgálja. Megállapítja, hogy az igei tartományban is megfigyelhető határozott-határozatlan szembenállás, és ez a főnévi tartománybeli határozott és határozatlan névelő közötti különbséghez hasonlítható, mégpedig a névelők szerepe alapján aszerint, hogy a diskurzusban ismert vagy új entitásra vonatkoznak-e. Az alábbi három igeidő képviseli az ilyen alapon megadható csoportokat:

present perfect: : mindig határozatlan

simple past: lehet határozott és határozatlan is

progressive: mindig határozott ${ }^{41}$

Mivel a progresszívet határozott igeidőként jellemzi, mint amelynek a referenciaideje a határozott névelő segítségével, „a t”-ként adható meg, nála is felmerül a többes számú határozott leírások problémája. A következő jellemzést adja a progresszívre:

A progresszivnak határozottnak kell lennie; a referenciaidejének kell, hogy legyen antecedense, vagy határozó segitségével kell azonositva lennie, és az idömódositók is a referenciaidöre vonatkoznak. ${ }^{42}$

\footnotetext{
${ }^{41}$ Szembetűnő a hasonlóság a főnévi csoportok esetében alkotható három csoporttal: 1) puszta köznevek 2) határozatlan névelős fönévi csoportok 3) határozott névelős főnévi csoportok. Kearns a névelők határozottsága alapján von párhuzamot az igeidőkkel, de az egyes igeidők jellemzése szerint a határozottság terminus itt inkább a specifikusságot takarja.

42 The progressive must be definite; the framed time must have an antecedent or be identified by an adverbial, and is also the target of durational modification. (Kearns 1991, 185. oldal)
} 
A 4.2. fejezetben volt szó a határozottság fogalmáról. Kearns az ismertség (familiarity) alapú és a kvantifikációs alapú megközelítést veti össze. A dinamikus reprezentációs szemantikák az ismertség fogalma alapján definiálják a határozottságot. Eszerint a diskurzusba előzőleg már bevezetett diskurzusreferens-antecedenssel rendelkező anaforikus kifejezés jelölete minősül ismertnek. A klasszikus, vagyis a névelők kvantifikációs alapú megközelítése a határozottságot az unicitási feltételhez köti, a határozott és határozatlan névelőt pedig a többi determinánshoz (például minden, néhány) hasonlóan kvantorként kezeli.

Kearns (1991) megállapítja, hogy mindkét elmélet által megfogalmazott szempontra szükség van, és amellett érvel, hogy a kvantifikációs megközelítés alapján levezethető az ismertség fogalma is. Különbséget tesz teljes és nem teljes határozott leírások között. A teljes határozott leírások esetében nincs szükség az ismertségi követelményre, mert ezeknek a kifejezéseknek az esetében a teljes univerzumon teljesül az unicitási feltétel. Ilyen kifejezés például a Végtelen történet címü könyv írója. A nem teljes határozott leírások esetében azonban van szerepe az ismertségnek, ilyen például $a$ busz. Az ilyen kifejezések esetében az értékelés alapja nem lehet az egész univerzum, mert ott nyilván nem teljesülne az unicitás, hanem egy szükebb kontextusra van szükség, ami a releváns környezetet adja meg, vagyis a releváns buszok halmazát, ami alapján már teljesülhet az unicitás. Ez a szükebb kontextus a diskurzus, ami Kearns szerint diskurzus-reprezentációs eszközökkel adható meg. Ha a diskurzusban egyetlen megfelelö diskurzusreferenst találunk, amely antecedensként szolgál az anafora számára, azzal teljesül az unicitás, de ez egyúttal azt is jelenti, hogy ez a diskurzusreferens már korábban be lett vezetve a diskurzusba, vagyis ismert. Így kvantifikációs alapon megragadható az ismertség fogalma is.

Kearns tehát minden határozott leírást kvantoros kifejezésnek tart, és amellett foglal állást, hogy a határozott névelő tulajdonképpen univerzális kvantor (Kearns (1991), 199. oldal). Megjegyzi ugyanakkor, hogy ha a határozott névelö jelentéséhez tartozónak tekintjük az unicitást, akkor nem tudjuk megmagyarázni a többes számú határozott leírások létét ( $a z$ elefántok). Kearns megoldása erre az, hogy a határozott leírások egyes vagy többes száma a köznévi predikátumon (elefánt - elefántok) múlik, 
vagyis az unicitás nem a névelőből ered, hanem a köznév egyes számú alakjából (ha egyes számú). Így a határozott névelőt mindkét esetben egységesen univerzális kvantornak lehet tekinteni. A hagyományos univerzális kvantortól (minden) eltérően a határozott névelőt olyan univerzális kvantornak tartja, amely egzisztenciális követelménnyel jár (unicitási követelménnyel azonban nem).

\subsubsection{Az események mint időpontok tulajdonságai (Montague 1969)}

Montague (1969) az események ontológiai státuszát tárgyalja annak a megfigyelésnek az alapján, hogy a nyelvben léteznek olyan mondatok, amelyekben az események is (más hasonló entitással együtt) individuumokhoz hasonlóan jelennek meg, mert tudnunk kell rájuk referálni. Montague három lehetséges megoldást mérlegel az események státuszára vonatkozóan. Az első megoldás szerint az eseményt az őt kifejező formulával azonosítjuk. Ennek a megoldásnak szerinte az a hátulütője, hogy nem tudunk mit kezdeni a kifejezhetetlen eseményekkel, ezért elveti ezt a lehetőséget. ${ }^{43}$

A második megoldás az, hogy az eseményekre halmazként tekintünk, mégpedig kizárólag azon objektumok halmazaként, amelyek kielégítik az adott formulát, vagyis azon pillanatok halmazaként, amelyek alatt az adott esemény végbemegy. Ebben az esetben nem merül föl ugyan a kifejezhetetlen események problémája, viszont egy másik igen: ha ugyanis két különböző esemény teljesen egy idöben zajlik, akkor szükségszerüen azonosként kell kezelnünk őket, mivel az általuk elfoglalt időintervallumok megegyeznek, és az idő az egyetlen szempont, ami alapján az eseményeket meghatározzuk. Ezért Montague ezt a lehetőséget is elveti.

A harmadik megoldás szerint az eseményeket tulajdonságoknak tekinti, méghozzá azon időpontok tulajdonságainak, amelyek alatt az adott esemény végbemegy. Az események általánosságban tehát tulajdonságok egy osztályának tekinthetők.

\footnotetext{
${ }^{43}$ Montague nem fejti ki, hogy mit ért kifejezhetetlen eseményeken; feltehetőleg azokat, amelyeket nem tudunk megadni egy formulával.
} 
Montague szerint ennek a megközelítésnek nagy elönye, hogy a fennállás (occurence) fogalma könnyen megragadható:

„Az, hogy egy P esemény fennáll egy $t$ idöpillanatban, egyszerüen annyit tesz, hogy t rendelkezik a P tulajdonsággal. "44

Montague (1969) alapján tehát ugyanúgy, ahogy az individuumok jellemezhetőek azokkal a predikátumokkal (tulajdonságokkal), amelyek igazak rájuk, az időpontok is jellemezhetőek azokkal az eseményekkel, amelyek fennállnak alattuk.

\subsection{A temporális kifejezések mint megszámlálható főnevek (Corazza 2002)}

Corazza (2002) temporális kifejezések szemantikai státuszát tárgyalja. Az időhatározókkal foglalkozó szakirodalom rendszerint a Kiefer által időmódosítóknak nevezett csoportot vizsgálja (például: $x$ idő alatt, $x$ ideig, $x$ időn keresztül). Corazza ezzel szemben az időpontot vagy intervallumot kifejező, „statikus” időhatározókat vizsgálja (this year 'ebben az évben', on Monday 'hétfőn'), azokat, amelyekről korábban láttuk, hogy temporális topikként megjelenhetnek progresszív mondatban (lásd 3.3.1. és 3.3.3. fejezet).

Corazza a nominális tartományon belül két csoportot különböztet meg: az indexikusokat egyrészröl, a tulajdonnevek, a megszámlálható köznevek és az anyagnevek csoportját másrészről. A tulajdonnevek persze a saját csoportjukon belül is külön alcsoportot alkotnak. A második csoportba tartozó kifejezésekre jellemző, hogy rögzült jelentésük van, a beszélőnek nincs dolga a név viselője és a jelentése közti kapcsolattal, csupán annyi, hogy a jelentésüknek megfelelően használja ezeket a kifejezéseket. Ezzel szemben az indexikus kifejezéseknél maga a beszélő teremti meg a kifejezés és a referenciája közti kapcsolatot. Corazza szerint a kérdés tehát az, hogy a vizsgált temporális kifejezések státusza a tulajdonnevekével, az indexikus

44 „To say that an event $\mathrm{P}$ occurs at a moment $\mathrm{t}$ is simply to say that $\mathrm{t}$ possesses (or partakes of, or participates in) the property P." (Montague (1969), 161. oldal) 
kifejezésekével vagy a megszámlálható köznevekével azonos. Az indexikus kifejezések csoportján belül Kaplan (1977) alapján megkülönbözteti továbbá az egyszerü (pure) indexikusokat (én, most, ma...) és a demonstratív kifejezéseket (ez, ott, ö...). Három kritériumot fogalmaz meg, amely alapján elkülöníthető a két alcsoport:

C1: Az egyszerü indexikusok használatához nem szükséges rámutató gesztus, szemben a demonstratívumokéval.

C2: Az egyszerű indexikusok használata nem percepció alapú, szemben a demonstratívumokéval.

C3: Az egyszerü indexikusok sohasem üresek (vacuous).

Az ebből a szempontból megvizsgálandó időhatározók például a következők: this year 'ebben az évben', next/last Monday 'következö/múlt hétfőn', on Monday 'hétfơn'. A temporális kifejezések között is vannak olyanok, amelyek egyértelműen indexikusok (this year), hiszen a fönévi indexikusok (this book 'ez a könyv') mintájára tartalmaznak mutatószót. Az ilyen temporális indexikusokat mégis eltérően értelmezzük a fönévi indexikusoktól. A különbség abból adódik, hogy míg a this book fönévi indexikus kifejezés egyértelműen demonstratív, hiszen ráutaló gesztus nélkül nem tudjuk megadni a referenciáját, a this year, next/last Monday temporális indexikus kifejezések nem igényelnek ilyen kiegészítő gesztust. Az ilyen kifejezéseket a beszédszituáció alapján, a beszédidőhöz képest értelmezzük. A temporális indexikusok tehát valójában egyszerü indexikusok, mert jelentésük azokkal adható meg (a most alapján). Corazza szerint a következő kérdés az, hogy mi a státusza azoknak a temporális kifejezéseknek, amelyek nem tartalmaznak mutatószót. Az alábbi példákban ilyen időhatározók szerepelnek, de a két mondatban látható két típus egymástól is különbözik (Corazza (2002) példái: 447. oldal, (1) és (2)): 
tanítás kezdődik-JELEN ELÖLJ-ön hétfő

'A tanítás hétfőn kezdődik.'

b) The teaching starts on a Monday.

a tanítás kezdődik-JELEN ELÖLJ-ön egy hétfő

'A tanítás egy hétföi napon kezdődik.'

A (87a)-ban az on Monday kifejezés valóban nem tartalmaz mutatószót, ennek ellenére indexikusként értelmezzük, hiszen a beszédidőhöz képest, az azt közvetlenül követő vagy közvetlenül megelőző hétfői napra gondolunk. ${ }^{45}$ Így a (87a) mondatban szereplő temporális kifejezés indexikus értelmezését azzal magyarázhatjuk, hogy az egy elliptikus szerkezet, amelyben nem jelenik meg a valójában ott levő mutatószó.

A tárgyalt temporális kifejezéseknek bizonyos előfordulásai azonban kizárják, hogy indexikusnak minősítsük őket, mint (87b) esetében, ahol az időhatározó kvantoros kifejezésként jelenik meg. Corazza megállapítja tehát, hogy a vizsgált temporális kifejezések nem tekinthetők (egységesen semmiképp sem) indexikusoknak. Ezek után a tulajdonnévi vagy a megszámlálható főnévi státusz között kell dönteni. Igaz, hogy (87b) esetében határozatlan névelő szerepel az időhatározóban, de a névelő jelenléte önmagában nem zárja ki, hogy tulajdonnévi státuszt tulajdonítsunk neki, ahogy a következőkben látható is lesz. Corazza a következő teszteket alkalmazza (Corazza (2002) példái: 447. oldal, (3) és (4)):

\section{A) Understanding-competence test (megértés-kompetencia teszt)}

88. a) I met a man.

én találkozik-MÚLT egy ember

'Találkoztam egy emberrel.'

\footnotetext{
${ }^{45}$ Azt, hogy a kettő közül melyikre, elsősorban az igeidő határozza meg. Múlt idejü ige esetén a megelöző, jelen vagy jövő idő esetén a következő hétfőt értjük rajta, de mindegyik esetben a beszédidőhöz viszonyítunk.
} 
b) I met a Paul.

én találkozik-MÚLT egy Paul

'Találkoztam egy bizonyos Paullal.'

Bár a két mondat hasonló felszíni szerkezetünek tünik, és mind a köznév, mind a tulajdonnév előtt grammatikus a névelő, az értelmezésük eltér. Corazza szerint (88b) mondatban valójában idézet szerepel, amelynek az értelmezése a következő: „találkoztam valakivel, akit Paulnak hívnak”. Ha feltételezzük, hogy (87b) esetében is idézet van, és ez a megfelelő értelmezést eredményezi, akkor az a temporális kifejezés (Monday) tulajdonnévi jellegét támasztaná alá. Az idézetes szerkezet azonban nem a kívánt jelentést adja, hanem a következőt: „a tanítás a hétnek egy olyan napján kezdődik, amelyet hétfőnek neveznek." Az értelmezés ott siklik félre, hogy nem tartalmazza azt, hogy tudjuk, a hét napjai közül melyik a hétfö. A (87b) és (88b) közti különbség azt mutatja, hogy a temporális kifejezés esetében tisztában kell lennünk a szó jelentésével, a tulajdonnév esetében azonban nem, vagyis a teszt eredménye a Monday kifejezés tulajdonnévi státuszát nem támasztja alá.

\section{B) Embedding-substitution test (beágyazás-helyettesítés teszt)}

Ezzel a teszttel Corazza azt mutatja meg, hogy a vizsgált temporális kifejezés viselkedése beágyazott mondatban is eltérő a tulajdonnevekétől (Corazza (2002) példái: 449. oldal, (1a), (3a), (1c), (3c), (1b) és (3b)):

89. a) Lois wishes to kiss Superman.

Lois kíván-JELEN csókol-INF Superman

'Lois szeretné megcsókolni Supermant.'

Loiswishes to kiss Clark Kent.

Lois kíván-JELEN csókol-INF Clark Kent

'Lois szeretné megcsókolni Clark Kentet.' 


\section{b) Lois wishes to meet a bachelor ====}

Lois kíván-JELEN találkozik-INF egy agglegény

'Lois szeretne találkozni egy agglegénnyel.'

Lois wishes to meet an unmarried man.

Lois kíván-JELEN találkozik-INF egy nőtlen férfi

'Lois szeretne találkozni egy nőtlen férfival.'

c) Lois wishes to visit on a Monday $=====$

Lois kíván-JELEN meglátogat-INF PRO-TSZ1 ELÖLJ-ön egy hétfő

'Lois szeretne eljönni hozzánk egy hétfőn.'

Lois wishes to visit us on the dayafter a Sunday.

Lois kíván-JELEN meglátogat-INF PRO-TSZ1 ELÖLJ-ön a nap után egy vasárnap

'Lois szeretne eljönni hozzánk egy vasárnapot követő napon.'

A (89a) mondatban a jól ismert fregei Hajnalcsillag/Alkonycsillag példájához hasonló következtetési sémát látunk. A két premissza igazságából, miszerint Lois meg akarja csókolni Supermant, illetve, hogy Superman azonos Clark Kenttel, nem következtethetünk a nyíl jobb oldalán álló mondat igazságára, hisz Loisnak nem kell tudnia a kettő azonosságáról. Ezzel szemben (89b) esetében, ahol egy megszámlálható főnév áll a mondatban, helyesen következtethetünk a nyíl jobb oldalán álló mondat igazságára, hiszen a köznév használatához tudnunk kell annak jelentését (itt definícióját, szinonímáját). A (89c) példában a vizsgált temporális kifejezést helyettesítjük annak definíciójával, a következtetés pedig ugyanúgy helyes, mint (89b) esetében. Ez azt mutatja, hogy a vizsgált temporális kifejezés a megszámlálható főnevekhez hasonlóan viselkedik e tekintetben is. 


\section{C) Szintaktikai koordinálhatóság}

Corazza harmadik érve azon alapul, hogy a szintaktikailag azonos szerepü összetevők koordinálhatóak (Corazza (2002) példái: 452. oldal, (11) és (12)):

90. a) *All the Pauls and bachelors are males.

Összes a Paul-TSZ és agglegény-TSZ van-TSZ/3 hímnemü-TSZ

'Minden Pál és agglegény hímnemü.'

b) All Mondays and vixens are unfriendly.

Összes hétfö-TSZ és nöstényróka-TSZ van-TSZ/3 barátságtalan

'Minden hétfö és nőstény róka barátságtalan. ${ }^{46}$

Az első mondatban (lásd 90a) egy tulajdonnevet kapcsolunk össze egy megszámlálható főnévvel, ami agrammatikus mondatot eredményez. A vizsgált temporális kifejezés koordinálása megszámlálható főnévvel (90b)-ben viszont grammatikus mondatot eredményez, vagyis szintaktikailag koordinálhatóak. Ez újabb érv amellett, hogy a temporális kifejezéseket a megszámlálható főnevekhez hasonlóan halmazjelölő kifejezéseknek tartsuk. Ráadásul a temporális kifejezések ugyanúgy alkothatnak kvantifikált kifejezéseket, mint a köznévi halmazjelölők (például minden szerdán, on a Monday 'egy hétfön').

A tesztek alapján Corazza konklúziója tehát az, hogy a vizsgált temporális kifejezések (Monday, year) 1) alapvetően olyanok, mint a megszámlálható főnevek, 2) alkothatnak összetetten idexikus kifejezéseket (this year 'ebben az évben'), ezek azonban nem demonstratívumok, hanem egyszerü indexikusok, de megjegyzi, hogy 3) a dátumok (például 2011.03.12-én) kivételt képeznek, mert azok valóban merev jelölök, vagyis tulajdonnévi státuszúak.

\footnotetext{
${ }^{46}$ A mondatok ilyen szó szerinti fordítása szerencsétlen, magyarul megfelelőbb lenne a következő: Minden Pál és minden agglegény hímnemü.

Minden hétfó és minden nöstény róka barátságtalan.

Ez nem módosít viszont a példák megítélésén, (90b)-nek ez a fordítása is elfogadhatóbb, mint (90a)-é.
} 


\section{A temporális általánosított kvantorok}

Az előző szakaszban bemutatott tanulmányok alapján, vagyis hogy az események időpontok tulajdonságainak tekinthetők (Montague (1969)), valamint hogy az időpontot vagy intervallumot jelölö temporális kifejezések (például hétfö, év stb.) a megszámlálható főnevekhez hasonló halmazjelölő kifejezések (Corazza (2002)), feltételezhetjük, hogy a teljes temporális kifejezések denotációja is tekinthető általánosított kvantornak, a főnévi csoportok mintájára. Ezt a feltételezést támasztja alá Dowty $(1979,1982)$, amikor a konkrét intervallumokat kifejező temporális kifejezések (például tegnap, csütörtökön) jelöletét halmazok halmazaként adja meg. Dowty szerint ugyanabból az okból érdemes az ilyen kifejezések denotációját intervallumok helyett intervallumok halmazának halmazaként megadni, amiért a PTQ-ban (Proper Treatment of Quantification) $)^{47}$ a főnévi csoportok nem egyszerűen individuumokat, hanem individuumok halmazának halmazát jelölik (lásd Dowty (1979), 326. oldal, Dowty (1982), 25. oldal) ${ }^{48,49}$ A dolgozat hátralevő részében ennek a feltételezésnek a nyelvi és formális vonatkozásairól lesz szó.

\footnotetext{
${ }^{47}$ Richard Montague:The Proper Treatment of Quantification in ordinary English In Patrick Suppes, Julius Moravcsik \& Jaakko Hintikka (eds.), Approaches to Natural Language. Dordrecht 1973

${ }^{48}, \ldots$... so it will be useful to have a category of English expressions $\mathrm{Tm}$ that denote sets of properties of times. This step is taken for essentially the same reasons as Montague used the category $\mathrm{T}$ to denote sets of properties of individuals..."(Dowty (1979))

„Let time adverbials (yesterday, on Thursday, etc.) be members of category TmAv, denoting (sets of sets of) intervals of time." (Dowty (1982))

„The reason that time adverbials are given this kind of denotation, rather than denoting intervals of time directly, is the same reason that noun phrases in PTQ are taken to denote sets of properties of individuals, rather than to denote individuals directly - to capture the quantificational aspect of the meaning of noun phrases." (Dowty (1982))

${ }^{49}$ Meg kell jegyezni, hogy Dowty az intervallumokat tekinti elemi egységeknek, és ezért adja meg az időhatározókat intervallumhalmazok halmazaként, a dolgozat viszont az időpontot fogja elemi egységnek tekinteni, ráadásul az aspektusra is tekintettel lesz, ezért a megoldás nem fog egyezni Dowtyéval. A temporális kifejezések ilyen megközelítését tekintve azonban mindenképpen alátámasztja a dolgozatban bemutatandó megoldást.
} 


\subsection{Mi felel meg a mondatban a temporális determinánsnak?}

A dolgozat első felében láthattuk, hogy a mondat aspektusa megszorítást jelent többek között a benne grammatikusan megjelenni tudó időhatározókra azok determinánsától függően. ${ }^{50}$ A kérdés tehát az, hogy az időhatározók determinánsa milyen szerepet játszik a mondat aspektusában.

A progresszív és a perfektív aspektus kapcsán hagyományosan úgy tartjuk, hogy a két esetben eltérő az eseményidő és a referenciaidő viszonya (lásd Partee 1984). Míg a perfektív aspektus esetében az eseményidő része a referenciaidőnek $(\mathrm{E} \subseteq \mathrm{R})$, a progresszív aspektus esetében ez a viszony fordított, mert ahogy a temporális keret olvasat is jelzi, a referenciaidő része az eseményidőnek $(\mathrm{R} \subseteq \mathrm{E})$. Vagyis az aspektus mindenképp valamiféle relációval kapcsolatos jelenség, mégpedig az időhatározóval jelölt referenciaidő, valamint az eseményidő közti relációval. Láttuk továbbá, hogy a progressszív aspektusú mondatokban csak olyan időhatározó jelenhet meg, amelyik temporális topik szerepü, azaz megfelel az unicitás és ismertség követelményének (lásd $(68 a-e))$.

Mindebböl arra a következtetésre juthatunk, hogy a temporális topikként álló időhatározó temporális általánosított kvantornak tekinthető, és az ő determinánsa határozza meg az időhatározóban szereplő halmazjelölő kifejezés és az esemény mint időpillanat-halmazjelölő kifejezés denotációja közötti relációt, vagyis azt, hogy milyen a mondat aspektusa. Ez a következtetés azonban nem állja meg a helyét, ahogy látni fogjuk. A következő példákban olyan időhatározók szerepelnek, amelyek megjelenhetnek progresszív aspektusú mondatban, ahogy ezt (91a) és (92a) mutatja.

91. a) Délben épp vitorláztam.

b) Délben felmásztam a fára.

92. a) Múlt szombaton épp vitorláztam.

\footnotetext{
50 Természetesen egyszerüsítek, amikor csak a megjelenő időhatározót említem, hiszen többféleképpen adható meg a referenciaidő, sőt olykor nem is nyelvi eszközökkel.
} 
b) Múlt szombaton meggyújtottam egy gyertyát és a kutyám sírjára tettem.

A fenti progresszív mondatokban szereplő időhatározók egy konkrét időintervallumot jelölnek, megfelelnek az unicitási követelménynek a határozott névelős vagy mutatószót tartalmazó fónévi csoportokhoz hasonlóan, tehát határozottak (lásd 4.2. fejezet). Ha helyes lenne az a feltételezés, hogy az időhatározó - mint temporális általánosított kvantor - determinánsa határozza meg az egyes aspektusok esetén megfigyelhető relációt a referenciaidő és az eseményidő között, abból az következne, hogy egy másféle aspektusú mondatban nem állhatnak ugyanolyan determinánsú időhatározók, mint amilyenek a progresszív aspektusúban. A fenti példasor azonban nem támasztja alá ezt a feltevést. Ugyanazok az időhatározók, amelyekkel progresszív mondatot alkottunk (lásd (91a) és (92a)), perfektív mondatban is megjelenhetnek (lásd (91b) és (92b)). Az időhatározók mindkétféle aspektusú mondat esetében változatlan formában szerepelnek, tehát nem indokolhatjuk az aspektusbeli eltérést azzal, hogy más a temporális általánosított kvantor determinánsa. Nyilvánvalóan azt sem mondhatjuk, hogy a két esetben más az időhatározók által kifejezett referenciaidő jelölete, az adott intervallum. Az egyetlen lehetséges megoldás erre az, hogy a temporális általánosított kvantorban determinánsi funkciót betöltő összetevő, ami meghatározza a referenciaidő és eseményidő közötti relációt, nem az időhatározón belül keresendő. ${ }^{51}$ Ez azonban azt is jelenti, hogy az időhatározó önmagában nem temporális általánosított kvantor (vagy pontosabban: nem az időhatározó a temporális általánosított kvantor).

A fenti példasor a) és b) mondatai kizárólag aspektusukban, illetve predikátumaikban térnek el. Igaz, a predikátumokat szándékosan úgy választottam, hogy a világtudásunk alapján egyértelmúen vagy a perfektív, vagy a progresszív olvasat jelenjen meg. Ez azonban nem jelenti azt, hogy a predikátumnak kellene tulajdonítani a mondatok közötti aspektuális különbséget, hiszen ha olyan predikátumot és időhatározót választunk, amelyek léptéküket tekintve nem olyan szélsőségesek, mint például a vitorlázás egy időponthoz (lásd 91a), vagy a gyertya meggyújtása egy teljes napnyi

\footnotetext{
${ }^{51}$ A látszólagos egybeesésnek az az oka, hogy az aspektusnak nincs testes morfémája, ahogy arról már volt szó (lásd 3.2. fejezet). A temporális általánosított kvantorban azonban, ha nem is nyíltan, jelen van a mondat aspektusát meghatározó függvény.
} 
időintervallumhoz képest (lásd 92b), akkor is létrejöhetnek a különböző aspektusú olvasatok, ahogy az alábbi példapár mutatja:

\section{3. a) Kettő és három között épp futottam.}

c) Kettő és három között futottam. (Utána felmentem Aurélhoz.)

Mivel a fenti predikátum igekötő nélküli ige, az egyértelmü olvasatokat egyéb eszközök segítségével jelöltem: az épp szócskával, illetve a diskurzus lehetséges folytatásával. Mindkét példában azonos predikátum és időhatározó szerepel, a mondatok aspektusa mégis eltérő, ami azt jelenti, hogy egyiküknek sem tulajdonítandó az időhatározó denotációja és az esemény között fennálló viszony. Kétségtelen ugyan, hogy a nyelvi kontextus vagy a világtudásunk a valós világra vonatkozóan befolyásolja, hogy melyik olvasat lehetséges, vagy ha mindkettő az, akkor melyiket részesítjük elönyben, de mindig alkotható olyan lehetséges világ, amelyikben nem érvényes az aktuális világra vonatkozó tudásunk, és nincs olyan nyelvi kontextus, ami befolyásolná az egyes olvasatok dominanciáját. Tartható tehát az a megállapítás, hogy nem is a predikátum a felelős az időhatározó és az esemény közötti viszonyért.

Ezek alapján kézenfekvő az a feltevés, hogy a temporális tartományban kizárólag az aspektuson múlik az időhatározó által jelölt referenciaidő és az esemény idejének a viszonya. A dolgozatban azt állítom, hogy az aspektus a referenciaidő és az eseményidő közötti reláció maga. Mivel azonban nem köthető egyetlen nyelvi elemhez ez a szerep, egy üres kategóriát fogok neki megfeleltetni. Bár ez nem ideális megoldás, nem is előzmény nélküli. A magyar mondat szerkezetének leírásában É. Kiss (1992) az igemódosítók mondatbeli helye alapján feltételez egy PROG és egy EXIST láthatatlan operátort, amelyek ugyanazt a pozíciót foglalják el a mondatban, amelyiket egyébként az igemódosító és a fókusz is, azaz a ragozott igét közvetlenül megelőző pozíciót. Ezzel magyarázza meg azokat az eseteket, amikor az igemódosítói pozícióban nem jelenik meg az igemódosító annak ellenére, hogy a mondat nem tartalmaz fókuszt. 
Feltételezhetjük tehát, hogy vannak szintaktikai érvek is amellett, hogy létezik a magyarban egy „láthatatlan” ASPEKTUS, aminek határozott szemantikai tartalma is van. Ezt a szemantikai tartalmat teszem explicitté a következö fejezetekben.

\subsection{A temporális modell: Kamp - Schiehlen (2001)}

Az alábbiakban egy olyan intervallumszemantikát mutatok be, amelynek elsődleges célja az, hogy a temporális kifejezések, és azok közül is elsősorban a naptári kifejezések (calendar terms) számítógépes kezelését tegye lehetővé.

Kamp - Schiehlen (2001) megkülönbözteti az időtartamot jelölő (measure), illetve a referenciális (calendar) temporális kifejezéseket. A temporális főnevek többnyire azonban egyszerre mindkétféle használatot lehetővé teszik, ahogy a (94-95) példák mutatják.

\section{Ezer éve nem láttuk egymást!}

95. Ebben az évben jó termés lesz.

Például az év, hónap, nap temporális főnevek egyszerre jelölhetnek időtartamot (lásd 94) és jelölhetnek ki az időskálán egy bizonyos intervallumot (lásd 95). Kamp - Schiehlen (2001) a temporális főneveknek ezt a kettősségét úgy kezeli, hogy különböző predikátumoknak tekinti őket. Az időtartamot kifejező temporális főnevek fordításaként álló predikátumok az $m$ alsóindexet viselik (például year $r_{\mathrm{m}}$ ), a referenciális temporális főnevekéi pedig a $c$ alsóindexet (például year c $_{\mathrm{c}}$. A két predikátumtípus között természetesen van kapcsolat, amit a későbbiekben ismertetek.

Kamp - Schiehlen (2001) az időt konceptuálisan folytonosnak (dense) és lineárisan rendezettnek tartja, amit végtelenül osztható intervallumoknak (periods) a teljes megelőzési és átfedési reláció segítségével lineárisan rendezett struktúrájaként kezel. A végtelen oszthatóság alól kivételt képez a minimális intervallum, amit nem is sorolnak a szerzők az intervallumok közé, sőt, fontosnak tartják megkülönböztetni 
azoktól, mint időpillanatot (moment of time). Ugyanakkor az elmélet szempontjából nem tartják fontosnak, hogy az időpillanatok alapján definiáljuk-e az intervallumokat vagy fordítva, vagy mindkettő atomi elemnek tekintendő-e, ezért nem foglalnak állást e tekintetben, de a feltételezett topológiai struktúra mindkét egységet tartalmazza: az időpontok között szigorú megelőzési reláció $(<)$ áll fönn, valamint az időpontok és az intervallumok között eleme relációt $(\mathrm{t} \in \mathrm{i})$ feltételeznek. ${ }^{52}$ Továbbá, minden $\left\langle\mathrm{t}\right.$, $\left.\mathrm{t}^{\prime}{ }^{\prime}\right\rangle$ rendezett párnak, amelyre t'< t'”, megfeleltethető egy ( $\mathrm{t}^{\prime}, \mathrm{t}^{\prime}$ ') intervallum. ${ }^{53}$ A Kamp Schiehlen-ben mondottak alapján (lásd 184-185. oldal) tehát a következő modellt állítom föl:

$\mathrm{M}:=\langle\mathrm{O}, \mathrm{E}, \mathrm{T}, \mathrm{I},<, \mathrm{O}, \mathrm{F}\rangle$, ahol

$\mathrm{O}:=\left\{\mathrm{a}_{1} \ldots \mathrm{a}_{\mathrm{n}}\right\}$ individuumok halmaza,

$\mathrm{E}:=\left\{\mathrm{e}_{1} \ldots \mathrm{e}_{\mathrm{n}}\right\}$ események halmaza, melynek elemei eseménypéldányok (token), és $\mathrm{O} \cap \mathrm{E}=\varnothing$.

$\mathrm{T}:=\left\{\mathrm{t}_{1} \ldots \mathrm{t}_{\mathrm{n}}\right\}$ és $\mathrm{T} \cap \mathrm{O}=\varnothing$ és $\mathrm{T} \cap \mathrm{E}=\varnothing$, amelyen egy szigorú rendezési relációt, a megelőzési relációt $(<)$ értelmezzük.

$$
\begin{aligned}
& \mathrm{I}:=\left\{\mathrm{i}_{1} \cup \ldots \cup \mathrm{i}_{\mathrm{n}}\right\} \text { és } \mathrm{T} \cap \mathrm{O}=\varnothing \text { és } \mathrm{T} \cap \mathrm{E}=\varnothing, \\
& \text { és minden } \mathrm{t}_{\mathrm{i}}, \mathrm{t}_{\mathrm{k}}, \mathrm{t}_{\mathrm{j}}-\mathrm{re}:\left(\left(\mathrm{t}_{\mathrm{i}} \in \mathrm{i}\right) \&\left(\mathrm{t}_{\mathrm{k}} \in \mathrm{i}\right) \&\left(\mathrm{t}_{\mathrm{i}}<\mathrm{t}_{\mathrm{j}}<\mathrm{t}_{\mathrm{k}}\right)\right) \rightarrow\left(\mathrm{t}_{\mathrm{j}} \in \mathrm{i}\right), \\
& \text { és minden } \mathrm{i}=\left\langle\mathrm{t}^{\prime}, \mathrm{t}^{\prime}{ }^{\prime}\right\rangle \text {-re: ha }\left\langle\mathrm{t}^{\prime}, \mathrm{t}^{\prime}{ }^{\prime}\right\rangle \in \mathrm{P} \subset \mathrm{T} \times \mathrm{T}, \text { akkor } \mathrm{i} \subseteq \mathrm{T} .
\end{aligned}
$$

F az interpretációs függvény, ami a lexikális nyelvi kifejezésekhez rendeli hozzá a modellbeli jelöletüket.

A T halmazon értelmezett < reláció tulajdonságai a következők:

Minden $t_{i}, t_{j}, t_{k} \in T-r e:$

$$
\sim\left(\mathrm{t}_{\mathrm{i}}<\mathrm{t}_{\mathrm{i}}\right) \text { (irreflexív) }
$$

\footnotetext{
${ }^{52}$ Kamp - Schiehlen (2001) valójában az időpillanat jelölésére itt használt t helyett i szimbólumot, az intervallum jelölésére itt használt $\mathrm{i}$ helyett pedig $\mathrm{p}$ (mint period) szimbólumot használ; az egységesség miatt használom mégis ezeket a jelöléseket.

53 Fontos megjegyezni, hogy az időpillanatok megkülönböztetésére használt (') aposztrofok száma semmilyen összefüggésben nincs az egyes időpillanatok sorrendjével, pusztán a megkülönböztetésüket szolgálja.
} 


$$
\begin{aligned}
& \left(\left(\mathrm{t}_{\mathrm{i}}<\mathrm{t}_{\mathrm{j}}\right) \&\left(\mathrm{t}_{\mathrm{j}}<\mathrm{t}_{\mathrm{k}}\right)\right) \rightarrow\left(\mathrm{t}_{\mathrm{i}}<\mathrm{t}_{\mathrm{j}}\right) \text { (tranzitív) } \\
& \left(\mathrm{t}_{\mathrm{i}}<\mathrm{t}_{\mathrm{j}}\right) \rightarrow \sim\left(\mathrm{t}_{\mathrm{j}}<\mathrm{t}_{\mathrm{i}}\right)(\text { aszimmetrikus) } \\
& \left(\mathrm{t}_{\mathrm{i}}<\mathrm{t}_{\mathrm{j}}\right) \vee\left(\mathrm{t}_{\mathrm{j}}<\mathrm{t}_{\mathrm{i}}\right)(\text { teljes (connected) })
\end{aligned}
$$

Az időpillanatok lineárisan rendezett $\mathrm{T}$ halmazának folytonos részhalmazai az intervallumok, amelyek jelölhetök olyan $\left\langle t^{\prime}, t^{\prime}\right.$ ' $\rangle$ rendezett párokként, ahol t' és t'” egy intervallum végpontjait jelölik. Ennek megfelelően $\left\langle\mathrm{t}^{\prime}, \mathrm{t}^{\prime}{ }^{\prime}\right\rangle \in \mathrm{P}$, ahol P a T-n értelmezett szigorú rendezési relációnak megfelelő rendezett párok halmaza, azaz $\mathrm{P} \subseteq \mathrm{T} \times \mathrm{T}$. A rendezett pár fogalma visszavezethető a (rendezetlen) halmaz fogalmára, hiszen egy kételemü $\left\{t^{\prime}, t^{\prime \prime}\right\}$ halmaz esetében a rendezés a következőképpen adható meg: $\left\{\left\{\mathrm{t}^{\prime}\right\}\left\{\mathrm{t}^{\prime}, \mathrm{t}^{\prime}{ }^{\prime}\right\}\right\}$. Ha egy rendezett halmaz minden tetszőleges kételemü részhalmazára fennáll a rendezés - tehát felírható rendezett párként -, akkor az adott rendezett halmaz tetszőleges részhalmazai is rendezettek (lásd Hausdorff-Birkhoff tétel). Mivel a $\mathrm{T}$ esetében a rendezési reláció tranzitivitásából következően ez fennáll, egyrészt a $\mathrm{T}$ minden $\mathrm{i} \subseteq \mathrm{T}$ részhalmaza szintén rendezett, másrészt minden $\langle\mathrm{t}$ ',t'” $\rangle$ rendezett pár egyértelmüen meghatározza T-nek egy i folytonos részhalmazát, amely tekinthető egy olyan $\mathrm{i}=\left\langle\mathrm{t}^{\prime}, \mathrm{t}^{\prime}\right.$ ' $\rangle$ intervallumnak, amelynek t' a kezdőpontja, t', pedig a végpontja, azaz ha $\left\langle\mathrm{t}^{\prime}, \mathrm{t}^{\prime}{ }^{\prime}\right\rangle \in \mathrm{P} \subseteq \mathrm{T} \times \mathrm{T}$, akkor $\mathrm{i} \subseteq \mathrm{T}$. A rendezett pár természetesen nem azonos az intervallummal, de egyértelműen meghatározza azt. Kamp - Schiehlen (2001) szerint ugyanakkor nincs empirikus jelentősége annak, hogy egy $\left\langle\mathrm{t}^{\prime}, \mathrm{t}^{\prime}\right.$ ' $\rangle$-ként jelölhető intervallum esetén a t' és t' 'időpillanatokat az intervallum elemeinek tekintjük-e vagy nem, vagyis hogy nyílt vagy zárt intervallumokat feltételezünk-e.

Továbbá, mivel Kamp - Schiehlen (2001) a hét $t_{\mathrm{c}}$, hónap $p_{\mathrm{c}}$, év predikátumokra helyezik a hangsúlyt, az alapegységet napnak tekintve megkülönböztetnek egy $t_{0}$ kezdőpillanatot, valamint egy második, $\mathrm{t}_{1}$ pillanatot, ahol $\mathrm{t}_{0}<\mathrm{t}_{1}$, amelyre $\left\langle\mathrm{t}_{0}, \mathrm{t}_{1}\right\rangle$ az első napnak, az egységnek tekintendő, $t_{0}$ kezdettel. Kamp - Schiehlen (2001) az intervallumok között négyféle relációt definiál (lásd a-d): a megelőzés $(<)$, az átfedés $(\circ)$, a részintervallum $(\subseteq)$ és az illeszkedés $(\supset \subset)$ relációt (Kamp - Schiehlen (2001), 185.oldal alapján, de rendezett párként jelölve az intervallumokat). 
a) megelőzés: Az i intervallum megelőzi j intervallumot, ha az i intervallum minden pontja megelőzi a $\mathrm{j}$ intervallum minden pontját.

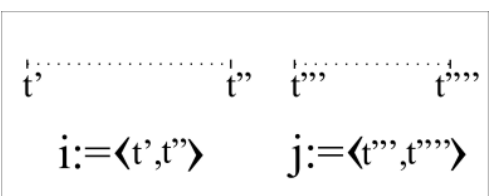

6. ábra

Bármely $\mathrm{i}=\left\langle\mathrm{t}^{\prime}, \mathrm{t}^{\prime}{ }^{\prime}\right\rangle$ és $\mathrm{j}=\left\langle\mathrm{t}^{\prime},{ }^{\prime}, \mathrm{t}^{\prime},{ }^{\prime},\right\rangle$ intervallumra:

$\mathrm{i}<\mathrm{j}$ akkor és csak akkor, ha minden $\mathrm{t}_{\mathrm{n}} \in \mathrm{i}$ esetén $\mathrm{t}_{\mathrm{n}}<\mathrm{t}$ ',

b) átfedés: Az i intervallum és a j intervallum átfedik egymást, ha van legalább egy közös pontjuk.

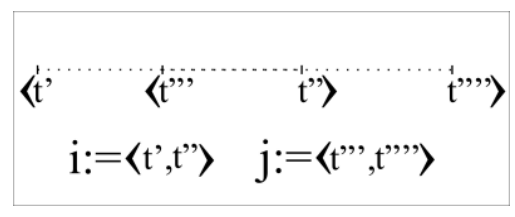

7. ábra

Bármely $i=\left\langle t^{\prime}, t^{\prime \prime}\right\rangle$ és $j=\left\langle t^{\prime \prime},, t^{\prime,},{ }^{\prime}\right\rangle$ intervallumra:

$\mathrm{i} \circ \mathrm{j}$ akkor és csak akkor, ha létezik olyan $\mathrm{t}_{\mathrm{n}} \in \mathrm{i}$, amelyre $\mathrm{t}_{\mathrm{n}} \in \mathrm{j}$, és $\sim(\mathrm{i} \subseteq \mathrm{j})$, és $\sim(\mathrm{j} \subseteq \mathrm{i})$

c) részintervallum: $\mathrm{Az} i$ intervallum részintervalluma a j intervallumnak, ha az $\mathrm{i}$ intervallum minden eleme $\mathrm{j}$-nek is eleme.

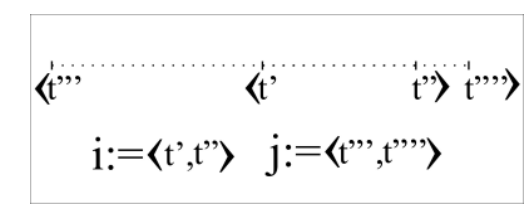

8. ábra

Bármely $i=\left\langle t^{\prime}, t^{\prime \prime}\right\rangle$ és $j=\left\langle t^{\prime},{ }^{\prime}, t^{\prime,},{ }^{\prime}\right\rangle$ intervallumra:

$\mathrm{i} \subseteq \mathrm{j}$ akkor és csak akkor, ha minden $\mathrm{t}_{\mathrm{n}} \in \mathrm{i}-\mathrm{re}: \mathrm{t}_{\mathrm{n}} \in \mathrm{j}$ 
d) illeszkedés: Az i intervallumhoz illeszkedik a j intervallum, ha i megelőzi j-t, és nincs közöttük egyetlen időpillanat sem.

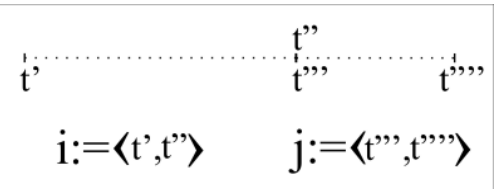

9. ábra

Bármely $i=\left\langle t^{\prime}, t^{\prime}{ }^{\prime}\right\rangle$ és $j=\left\langle t^{\prime},{ }^{\prime}, t^{\prime},{ }^{\prime}{ }^{\prime}\right\rangle$ intervallumra:

$\mathrm{i} \supset \subset \mathrm{j}$ akkor és csak akkor, ha $\mathrm{i}<\mathrm{j}$, és $\sim \exists \mathrm{t}_{\mathrm{n}}\left(\mathrm{t}^{\prime}{ }^{\prime}<\mathrm{t}_{\mathrm{n}}<\mathrm{t}^{\prime}{ }^{\prime \prime}\right)$

e) Ezen kívül az illeszkedő intervallumoknak az összegét a következőképp adják meg:

Bármely $\mathrm{i}=\left\langle\mathrm{t}^{\prime}, \mathrm{t}^{\prime}{ }^{\prime}\right\rangle$ és $\mathrm{j}=\left\langle\mathrm{t}^{\prime}, \mathrm{t}^{\prime}{ }^{\prime \prime}\right\rangle$ intervallumra, ahol $\mathrm{i} \supset \subset \mathrm{j}: \mathrm{i}+\mathrm{j}=\left\langle\mathrm{t}^{\prime}, \mathrm{t}^{\prime \prime}{ }^{\prime}\right\rangle$

Továbbá, az időtartamot kifejező temporális főnevek kezeléséhez feltételeznek egy további relációt, az "egyenlő hosszú” (三) ekvivalencia relációt, amely a következő megállapításokat vonja maga után:

$£ 12$ Bármely $i_{1}, i_{2}, i_{3}, i_{4}$ intervallumra:

Ha $i_{1} \supset \subset i_{2}$ és $i_{3} \supset \subset i_{4}$, továbbá $i_{1} \equiv i_{2}$ és $i_{3} \equiv i_{4}$, akkor $i_{1}+i_{2} \equiv i_{3}+i_{4}$

Az egyes intervallumok hosszúság alapján történő összevetését a Size Comparison elve (SCP) adja meg azonos kezdetü intervallumok esetén (lásd £13), illetve általánosítva (lásd £14):

$£ 13$ Bármely $i=\left\langle t^{\prime}, t^{\prime \prime}\right\rangle$ és $j=\left\langle t^{\prime \prime}, t^{\prime \prime},{ }^{\prime}\right\rangle$ intervallumra, ahol $t^{\prime}=t^{\prime \prime}$, :

$$
\mathrm{i}=\mathrm{j} \quad \vee \quad \exists \mathrm{k}(\mathrm{j}=\mathrm{i}+\mathrm{k}) \vee \exists \mathrm{k}(\mathrm{i}=\mathrm{j}+\mathrm{k})
$$


$£ 14$ Bármely i és j intervallumra:

$\mathrm{i} \equiv \mathrm{j} \vee \exists \mathrm{k} \exists \mathrm{l}(\mathrm{j}=\mathrm{k}+\mathrm{l}) \wedge \mathrm{k} \equiv \mathrm{i} \vee \exists \mathrm{k} \exists \mathrm{l}(\mathrm{i}=\mathrm{k}+\mathrm{l}) \wedge \mathrm{k} \equiv \mathrm{j}$

rövidített formában (SCP'): $\mathrm{i} \equiv \mathrm{j} \vee \mathrm{i} N \mathrm{j} \vee \mathrm{j} N \mathrm{i}$

Az intervallumok hosszúságára vonatkozó (三) és $N$ reláció egy szigorú álrendezést (pszeudo-ordering) eredményez (Kamp - Schiehlen (2001), 186.oldal).:

- $N$ tranzitív és aszimmetrikus

- 三 kongruencia reláció N-re vonatkozóan

$-\mathrm{SCP}^{\prime}: \mathrm{i} \equiv \mathrm{j} \vee \mathrm{i} N \mathrm{j} \vee \mathrm{j} N \mathrm{i}$

- az SCP'-ben szereplő diszjunkció kizáró jellegű

Két további fontos elv a Metrikus Kapcsolódás (Metric Connectedness) és a Metrikus Határtalanság (Metric Unboundedness) elve, a naptári terminusok kezeléséhez azonban csak az utóbbi szükséges (Kamp - Schiehlen (2001), 186.oldal).:

Metrikus Kapcsolódás: bármely i és $\mathrm{j}$ intervallumra, ahol $\mathrm{i}<\mathrm{j}$, létezik olyan $\mathrm{k}_{\mathrm{n}} \equiv \mathrm{i}$, amelyet i-hez illesztve $n$ véges számú lépésben eljutunk j-hez úgy, hogy $k_{n}$ átfedje $\mathrm{j}$-t, illetve létezik olyan $1_{m} \equiv j$, amelyre igaz, hogy j-hez illesztve m véges számú lépésben eljutunk ihez úgy, hogy $1_{m}$ átfedje i-t.

Metrikus Határtalanság: bármely i és j intervallumra létezik olyan k intervallum, amelyre $\mathrm{k} \equiv \mathrm{j}$ és $\mathrm{k} \supset \subset \mathrm{i}$, valamint létezik olyan 1 intervallum, amelyre $\mathrm{l} \equiv \mathrm{i}$ és $\mathrm{l} \supset \subset \mathrm{j}$

A naptári kifejezések predikátumainak mindegyike teljes partíciót jelent az időskálán, amely lehetővé teszi, hogy az időt mintegy diszkrét elemek halmazaként kezeljük. Az egyes naptári kifejezéseknek (például tavaly, 2012. június 2.) megfeleltethető időtartamot jelölő kifejezések (év, nap) jelölete megadható az egyes naptári predikátumok jelöletének $\equiv$ reláció szerinti lezárásával. Ezek alapján a temporális kifejezések közül a naptári kifejezések egyetlen intervallumot denotálnak, míg az 
időtartamot kifejezők egy a $\equiv$ reláció szerinti egész ekvivalenciaosztályt. Az egyes eltérések, például a hónapok és évek napszámának eltérése eseti megoldásokkal kezelendők.

A naptári terminusok egyes partíciók közötti hierarchiáját a Calendar Granularity Hierarchy (CGH) adja meg, amelynek elemeire fajtaként (sort) vagy fajta (sortal) predikátumként hivatkozik Kamp - Schiehlen (2001), és a fajtákat a predikátumok intenziójának tekinti. Minden naptári kifejezés fajtája a CGH-nak egy olyan fajtája, ami a naptári kifejezés lehetséges denotációját elemként tartalmazza.

Kamp - Schiehlen (2001) a naptári terminusok referenciális feltételeit is a CGH segítségével adja meg. A naptári terminusok jelöletét egyetlen intervallumként határozták meg, amihez azonban bizonyos feltételeknek teljesülnie kell. Például a június 6. kifejezés jelölete csak akkor lehet egyetlen intervallum, ha a kontextus egy bizonyos évre van leszükítve. Kamp - Schiehlen (2001) megállapítja, hogy az adott naptári terminus és annak unikális jelölete között szisztematikus megfelelés van. Az a kontextus, amelyben az adott terminus unicitása teljesül, maga is eleme egy temporális predikátum jelöletének, mégpedig tipikusan az "eggyel magasabb" partícióba tartozónak:

96. Júniusban

97. Kedden

98. du. háromkor

A júniusban ${ }_{\mathrm{c}}$ idöhatározónak a jelölete abban az esetben egyetlen intervallum, ha a kontextus által ki van jelölve egy bizonyos év. Az év pedig tekinthető a hónapok átali tagolás közvetlen fölöttesének a CGH-ban. Ugyanígy a kedden idöhatározó (lásd (97)) akkor jelöl egyetlen napot, ha kontextuálisan adott egy bizonyos hét, amelynek a napjáról van szó. A hét közvetlenül a nap fölötti mértékegység. És végül a délután háromkor időhatározó (lásd 98) számára is a kontextus által kijelöltnek kell lennie egy “eggyel nagyobb” mértékegységnyi intervallumnak ahhoz, hogy az időhatározó jelölete 
teljesítse az unicitást. ${ }^{54}$ Kamp - Schiehlen (2001) szerint a CGH segítségével adhatjuk meg azt a releváns predikátumot, ami ezt a kontextuális megszorítást jelenti, mert az a temporális kifejezés legmagasabb fajtájú predikátumánál eggyel magasabb partícióba tartozó predikátum.

Mivel az összetett időhatározóknak (pédául tegnap délután kettő elött tíz perccel) szintaktikailag bizonyos szerkezetet kell tulajdonítani, és ezek lehetnek különbözőek az egyes összetételek esetében, ahhoz, hogy a CGH segítségével meg tudjuk adni a releváns predikátumot, Kamp - Schiehlen (2001) szerint feltételezni kell egy függvényt, ez a Granularity Spectrum (GS), ami minden ilyen temporális kifejezéshez hozzárendeli azoknak az időjelölőknek a halmazát, amelyek szerepelnek benne, ami a fenti példát tekintve a következő: GS(kedden délután kettö elött tíz perccel $)=\left\{\right.$ nap $_{\mathrm{c}}$, napszak $_{\mathrm{c}}$,óra $\mathrm{c}_{\mathrm{c}}$ perc $c_{\mathrm{c}}$. A kedden délután kettő elött tíz perccel $l_{\mathrm{c}}$ időhatározó esetében a CGH alapján a $n a p_{\mathrm{c}}$ a legnagyobb mértékegység, az ennél eggyel nagyobb pedig a hét, ez utóbbi jelenti azt a kontextuális megszorítást, amin belül így az adott temporális kifejezésre (kedden délután kettö elött tíz perccel $l_{\mathrm{c}}$ ) teljesül az unicitás, vagyis a szemantikai státusza a határozott leírásokéval azonos.

\subsection{Referencialitás a temporális tartományban}

\subsubsection{Temporális anaforák (Partee 1984)}

A főnévi és temporális tartomány párhuzamosságát mutatja meg Partee (1984) az egyszerü múlt idő referenciális jellegének megállapításával. Amellett érvel, hogy a temporális tartományban ugyanúgy beszélhetünk anaforákról, mint a nominális tartományban, és ezek egységesen kezelendőek. A főnévi tartománybeli anaforákhoz

\footnotetext{
${ }^{54} \mathrm{Az}$ adott értelmezést befolyásolja még az igeidő is, mert például a du. háromkor időhatározó más-más intervallumot jelöl attól függően, hogy a mondat múlt idejü vagy jelen idejü:

i) Délután háromkor átmentem Aurélhoz.

ii) Délután háromkor átmegyek Aurélhoz.
} 
hasonlóan a temporális anaforáknak is több fajtáját különbözteti meg, amelyek közül itt kettőt említek példának (Partee (1984) példái: 244. oldal, (1a-b) és 246. oldal, (3a-b)).):

99. a) She left me.

Ö elhagy-MúLT PRO-E/1

'Elhagyott engem.'

b) I didn't turn off the stove.

Én NEG-MÚLT kapcsol ki a kályha

'Nem kapcsoltam le a kályhát.'

100. a) Pedro owns

a donkey. He beats

it.

Pedro birtokol-JELEN-E/3 egy szamár. Ö üt-JELEN-E/3 az

'Pedrónak van egy szamara. Üti.'

b) Mary woke up sometime during the night. She turned on the light.

Maryébred-MúLTfel valamikor alatt az éjszaka.Ö kapcsol-MúLTfel avillany

'Mary felébredt valamikor az éjszaka folyamán. Felkapcsolta a villanyt.'

Ugyanúgy, ahogy a (99a)-ban - a főnévi tartomány esetében - a névmási anafora (she) antecedense, a temporális tartomány esetében (lásd 99b) az eseményidő antecedense is a diskurzusból azonosítható. ${ }^{55}$ Partee megállapítja, hogy a (99b) mondat nem azt jelenti, hogy nem létezik olyan időpont, amelyre igaz lenne, hogy lekapcsoltam a kályhát, hanem azt, hogy a diskurzusban adott egy bizonyos időpont (a salient 'kiemelkedö'), amelyre igaz, hogy akkor nem kapcsoltam le. A predikátumtagadás segít annak megmutatásában, hogy az adott időpont létezése nem állításként, hanem előfeltevésként van jelen, hiszen a mondatban leírt esemény létezése - és így az eseményidő létezése is -a tagadással nem vonható vissza (lásd még 3.3.2. fejezet, (57a-b)). A mondatok közötti

\footnotetext{
${ }^{55}$ A jelenidő, illetve az egyes szám első személyủ névmás nem tartozik ide, mert azok indexikusak, kimondottan a beszédidőre és a beszélöre vonatkoznak, antecedensük nem változhat a szituációban való kitüntetettség alapján, jelöletük rögzítve van (lásd később: Corazza 2002).
} 
temporális anaforikus kapcsolatra példa (100b), ami szintén hasonló a főnévi tartománybeli mondatok közötti anaforikus kapcsolathoz (lásd 100a).

\subsubsection{Az időre való referálás eszközei: Blackburn (1994)}

A múlt időnek ezt a referenciális jellegét kívánja kezelni Blackburn (1994), amikor a John ran 'John futott' mondat ábrázolásaképp a hagyományos priori $\mathrm{P}(\mathrm{J} o h n$ run) helyett a következő formulát adja meg (Blackburn (1994), 4. oldal):

101. John ran.

John fut-MÚLT

'John futott.'

$\mathrm{P}(\mathrm{i} \wedge \mathrm{John} \text { run })^{56,57}$

A John run mondatgyök egy konkrét eseményt jelöl, aminek a temporális nyomát Blackburn egy új fajta propozíciós szimbólum $(i, j, k, \ldots \in N O M)$ bevezetésével adja meg, a nominálissal (nominal). Az ismert propozíciós szimbólumok VAR halmaza a NOM halmazával együtt alkotja az ATOM (atomi szimbólumok) halmazt, és $\mathrm{NOM} \cap \mathrm{VAR}=\varnothing$. Az $\mathbf{M}:=\langle\mathbf{T}, \mathrm{V}\rangle$ modellben, ahol $\mathbf{T}:=\langle T,<\rangle, \mathrm{V}$ az interpretációs függvény, ami ATOM elemeihez rendeli hozzá Pow $(T)$ elemeit, és minden $i \in N O M-h o z$ $T$ valamely egyelemü részhalmazát rendeli. Tehát egy nominális egy tetszőleges modellben pontosan egy időpontra igaz, így tulajdonképpen "megnevezi" azt az egyetlen időpontot, amelynél igaz. Így megragadható a John ran mondat referenciális jellege, mert ahhoz, hogy a mondat igaz legyen, nem elég, hogy legyen olyan időpont a múltban, amelyre igaz az állítás, hanem kimondottan a V(i) által kijelölt időpontban kell

\footnotetext{
${ }^{56} \mathrm{P}$ itt a múltidő operátora.

57 A dolgozat során az i szimbólumot időintervallumok jelölésére használom, ezért a továbbiakban a Blackburnnél a nominálist jelölő i szimbólumot $\chi$ szimbólummal helyettesítem.
} 
igaznak lennie. Ezzel a megoldással megragadható a mondatok közötti anaforikus kapcsolat is, mint például az alábbi mondat esetében ((100b) példa megismétlése).

100.b) Mary woke up sometime during the night. She turned on the light.

'Mary felébredt valamikor az éjszaka folyamán. Felkapcsolta a villanyt.'

$\mathrm{P}(\mathrm{i} \wedge$ Mary felébred valamikor az éjszaka folyamán $) \wedge \mathrm{P}(\mathrm{j} \wedge \mathrm{Pi} \wedge$ Felkapcsolja a villanyt $)$

Az első mondat ábrázolása megegyezik a korábbi példáéval (lásd John ran). A második mondaté viszont már összetettebb. A mondat egésze ugyanúgy a múlt idő operátor hatókörében van, a villany felkapcsolásának eseménye azonban más időpontban történt, mint a felébredés, ezért új nominálissal kell megadni ezt az időpontot (lásd j). Ahhoz, hogy a két mondat közötti szekvenciális olvasatot megragadjuk, nem elég pusztán egy újabb, j időpont bevezetése a második eseményre, hanem azt is jelölni kell, hogy az első mondat eseményideje megelőzi a másodikét. Ezt szolgálja a második mondatot ábrázoló formulában a Pi részformula, ami azt jelöli, hogy a mondat egészéhez képest az előző i eseményidő a múltban van.

\subsubsection{A mondatok feltételezett temporális szerkezete}

Bár Blackburn (1994) nominális logikáját eredetileg időpontokra építi, megjegyzi, hogy intervallum alapúvá is lehet tenni, amihez újabb propozíciós szimbólumot vezetne be $(\mathrm{e}, \mathrm{d}, \mathrm{c} . . . \in \mathrm{INOM})$, amelynek a segítségével időpontok helyett intervallumokat rendelhetünk a kiterjedt eseményekhez. A dolgozatban azonban én nem vezetek be időpontokra és intervallumokra vonatkozó különböző propozíciós szimbólumokat, hanem minden esemény nyomát intervallumként kezelem. Blackburn (1994) továbbá az indexikusok (például tegnap, holnap) és a naptári terminusok kezelését hasonlóképpen újabb atomi szimbólumok bevezetésével oldja meg, bővítve ATOM-ot 
(ATOM:=NOM $\cup$ VAR $\cup \mathrm{CAL} \cup\{$ ma, holnap...\}), és a következőképp ad meg egy ilyen kifejezést tartalmazó mondatot (Blackburn (1994) példája, 12. oldal)

\section{John reached the summit of Ruapehu at three o'clock.}

John elér-MÚLT a csúcs ELÖLJ-GEN Ruapehu ELÖLJ-kor három óra

'John három órakor elérte a Ruapehu csúcsát'

$\mathrm{P}$ (három óra $\wedge$ John eléri a Ruapehu csúcsát')

A (102) tartalmaz egy időhatározót, ami átveszi a nominális helyét a fenti ábrázolásban, mivel az időhatározó a mondatban leírt esemény eseményidejét adja meg. Az időhatározó és a nominális azonosítása azonban csak azért lehetséges itt, mert Blackburn nem kezeli az aspektust. Az aspektus vizsgálata szempontjából ugyanis éppen a referenciaidőt jelölö időhatározó (ami a (102)-ben a három órakor) és az eseményidő (amit alapvetően a nominális jelöl) közötti viszony releváns, mert az a különböző aspektusú mondatok esetében eltérő. A dolgozatban tehát Blackburn (1994)-től eltérően az időhatározót nem azonosítom a nominálissal, hanem mindkettőt szerepeltetem az ábrázolásban, önálló jelölettel.

Feltételezem továbbá a szintaktikai típusok Type halmazát, amelynek részhalmaza az alaptípusok BaseType: $=\{e, \varepsilon, t, \tau\}$ halmaza. Továbbá ha $\alpha \in$ Type és $\beta \in$ Type, akkor $\langle\alpha, \beta\rangle \in$ Type. Ha $\alpha \in$ Type, akkor megadható Term $\alpha$, az $\alpha$ típusú jólformált kifejezések halmaza. Továbbá, minden $\alpha$ típushoz hozzárendelhető egy $\mathrm{D}_{\alpha}$ tartomány, az $\alpha$ típusú kifejezések jelöletének tartománya. Ha tehát $\delta \in \mathrm{Term}_{\alpha}$, akkor $[[\delta]] \in \mathrm{D}_{\alpha} . \mathrm{Az} \quad \mathrm{M}:=\langle\mathrm{O}, \mathrm{E}, \mathrm{T}, \mathrm{I},<, \circ, \mathrm{F}\rangle$, modellben a különböző típusú nyelvi kifejezések szemantikai értéke a következőképp adható meg:

$\left[\left[\delta_{e}\right]\right] \in \mathrm{O}$, vagyis az $e$ típusú kifejezések jelölete a modellben egy individuum.

$\left[\left[\delta_{\varepsilon}\right]\right] \in \mathrm{E}$, vagyis az $\varepsilon$ típusú kifejezések jelölete a modellben egy esemény.

$\left[\left[\delta_{\tau}\right]\right] \in \mathrm{T}$, vagyis a $\tau$ típusú kifejezések jelölete a modellben egy időpont. 
$\left[\left[\delta_{t}\right]\right] \in\{0,1\}$, vagyis a $t$ típusú kifejezések jelölete a modellben egy igazságérték

$\left[\left[\delta_{\langle\alpha, \beta\rangle}\right]\right] \in\left[\left[\varphi_{\beta}\right]\right]^{\left[\left[\psi_{\alpha}\right]\right]}$, vagyis ha $\delta$ egy $\langle\alpha, \beta\rangle$ típusú kifejezés akkor $\delta_{\langle\alpha, \beta\rangle}$ szemantikai értéke egy olyan függvény, amely az $\alpha$ típusnak megfelelő szemantikai értéket leképezi a $\beta$ típusnak megfelelő szemantikai értékre.

Feltételezek továbbá egy tr (trace function) temporális nyom függvényt, ami egy eseményhez hozzárendeli az adott esemény temporális nyomát, azaz $\varepsilon$ típusú kifejezésekböl $\langle\tau, \tau\rangle$ típusúakat képez.

A következőképp ábrázolok tehát egy időhatározót tartalmazó mondatot:

103. Múlt szombaton Aurél (éppen) vitorlázott.

$\mathrm{P}($ múlt szombaton $\wedge$ Aurél vitorlázik $\wedge \chi)$

A szóban forgó eseményt kifejező mondatgyök (lásd Aurél vitorlázik) $\varepsilon$ típusú kifejezés, jelölete a modellben egy e $\in \mathrm{E}$ esemény, amelyhez a $\operatorname{tr}: \varepsilon \rightarrow\langle\tau, \tau\rangle$ temporális nyom függvénnyel rendeljük hozzá a temporális nyomát, vagyis az eseményidőt (lásd $\chi$ ). Az események így képzett temporális nyoma azonos a Blackburn által bevezetett nominálissal (lásd 6.3.2. fejezet $i \in \mathrm{NOM}$ ). Mivel azonban én a dolgozatban az általa használt szimbólumokat (lásd i, j stb.) időintervallumok jelölésére használom, az esemény temporális nyomát máshogy jelölöm (lásd $\chi$ ), amelynek tartalma azonban megegyezik a nomináliséval.

A dolgozatban az eseményeknek a deskriptív tartalmával nem, csak a temporális nyomával foglalkozom, vagyis azzal az intervallummal, amit a tr temporális nyom függvény rendel hozzá az eseményekhez. A temporális nyom függvény alkalmazásának eredményeképpen létrejövő $\langle\tau, \tau\rangle$ típusú nominális jelölete tehát pontosan az az intervallum lesz, amely alatt e fennáll, (lásd eseményidő):

$$
[[\chi]]=\operatorname{tr}[[\text { Aurél vitorlázik }]]=\mathrm{j}
$$


A mondatban szereplő időhatározóhoz (lásd múlt szombaton) a 6.2. fejezetben definiált $\mathrm{M}:=\langle\mathrm{O}, \mathrm{E}, \mathrm{T}, \mathrm{I},<, \circ, \mathrm{F}\rangle$ modell $\mathrm{F}$ interpretációs függvénye egy i intervallumot rendel jelöletként (ami egy $\left\langle\mathrm{t}^{\prime}, \mathrm{t}^{\prime \prime}\right\rangle$ rendezett párként jelölhető, amely az intervallum végpontjait tartalmazza: $\left\langle\mathrm{t}^{\prime}, \mathrm{t}^{\prime}{ }^{\prime}\right\rangle \in \mathrm{P}$ és $\mathrm{P} \subseteq \mathrm{T} \times \mathrm{T}$, ahol $\mathrm{P}$ a $\mathrm{T}$-n értelmezett $<$ relációnak megfelelő halmaz). A temporális topikként álló időhatározói kifejezés (lásd referenciaidő) $\langle\tau, \tau\rangle$ típusú kifejezés: $\operatorname{Adv} \in \operatorname{Term}_{\langle\tau, \tau\rangle}$, szemantikai értéke a 6.2. fejezet alapján $\left[\left[\operatorname{Adv}_{\langle\tau, \tau}\right]\right] \in \mathrm{P}$ $\subseteq \mathrm{T} \times \mathrm{T}$, azaz $\left[\left[\operatorname{Adv}_{\langle\tau, \tau]}\right]\right] \subseteq \mathrm{T} . \mathrm{A}(103)$ példamondat esetében ez a következö:

$$
\left[\left[\text { múlt szombaton }_{\langle\tau, \tau)}\right]\right]=\mathrm{i}
$$

A 6.1. fejezetben megmutattam, hogy annak ellenére, hogy a progresszív aspektusú mondat megszorítást tesz a benne megjelenő időhatározók determinánsára, nem az időhatározóban szereplő determináns határozza meg a referenciaidő és az eseményidő által jelölt intervallumok - vagyis rendezett időpillanat-halmazok - közötti relációt, hanem az egyetlen konkrét nyelvi elemhez nem köthető nézőpont aspektus, amit épp ezzel a relációval azonosítok. Mivel minden mondat rendelkezik valamilyen nézőpont aspektussal - amit különböző nyelvi jegyek segítségével a legtöbb esetben azonosítani tudunk, különösen a progresszív és egzisztenciális aspektusoknál - igazságértéket csak aspektussal rendelkező mondathoz rendelhetünk. Mivel az aspektus az álláspontom szerint a referenciaidő és az eseményidő közötti reláció, igazságértéket olyan mondat kaphat, amelyben ott van mind az expliciten megjelenő vagy impliciten kikövetkeztethető időhatározó által jelölt referenciaidő, mind az eseményidő. Mindezek alapján a mondatok szemantikai szerkezete a következőképpen írható le.

A főnévi tartományban a determinánsokat két halmaz közötti relációnak, vagy ezzel ekvivalensen - olyan függvénynek tekintjük, amelynek az argumentuma maga is egy függvény. Az általánosított kvantorként interpretálható kifejezések egy determinánsból és egy halmazjelölő kifejezésből állnak, és egy predikátum kifejezéssel együtt alkotnak mondatot, amelyhez igazságértéket rendelhetünk. A dolgozatban 
bemutatott érvelés szerint jól megalapozott az a feltevés, hogy a temporális tartományban is létezik ilyen tagolás. A bemutatott elméleti keretben ez egyrészt azt jelenti, hogy az aspektus egy időhatározói kifejezéssel - esetünkben a múlt szombaton időhatározóval - temporális általánosított kvantort alkot, másrészt - és ebből következően - azt, hogy az aspektus, ami a példamondatunkban a progresszív aspektus, ugyanazt a funkciót tölti be a temporális tartományban, mint a fönévi tartományban a determináns. A 103. mondattal illusztrálva tehát a következőképp jön létre egy $t$ típusú kifejezés:

$£ 15 \quad\left[A S P_{\langle\langle\tau, \tau\rangle,\langle\tau, \tau\rangle, t\rangle\rangle}(\text { Múlt szombaton) }\langle\tau, \tau\rangle \text { (Aurél (éppen) vitorlázott. })_{\langle\tau, \tau\rangle}\right]_{t}$

\subsection{Az általánosított kvantorok elmélete a temporális tartományban}

Mivel az általánosított kvantorok elmélete halmazalapú elmélet, a progresszív mondatok temporális tulajdonságainak vizsgálata során pedig a $\mathrm{T}$ halmazon értelmezett rendezés következtében rendezett halmazokkal, vagyis intervallumokkal van dolgunk, az elméletet át kell ültetni intervallumokra. Az 5.1. fejezetben bemutatott eredeti definíciókat (Barwise-Cooper (1981)) a következőképp fogalmazhatjuk át, megadva az egyes temporális kifejezések jelöletét:

SZT1: Ha $\eta$ egy $\langle\tau, \tau\rangle$ típusú, temporális intervallumot, vagyis rendezett halmazt jelölő kifejezés, akkor a jelölete a következőképp adható meg:

$$
[[\eta]] \in \mathrm{P} \subseteq \mathrm{T} \times \mathrm{T}, \text { ami meghatároz egy } \mathrm{i} \subseteq \mathrm{T} \text { intervallumot }
$$

Vagyis egy $\langle\tau, \tau\rangle$ típusú temporális intervallumot jelölő kifejezés interpretálható olyan függvényként, ami a $\mathrm{T}$ temporális univerzum egy t' eleméhez hozzárendeli a $\mathrm{T}$ temporális univerzum egy t” elemét, amely így a T-n értelmezett reláció egy eleme, egy 
rendezett pár lesz. Kamp - Schiehlen (2001) alapján egy naptári temporális predikátum (például $n a p_{\mathrm{c}}$ ) jelölete a T-n létrehoz egy partíciót (a számegyeneshez hasonlóan egy $\mathrm{t}_{0}$ kezdő viszonyítási időpont és egy $\mathrm{t}_{1}$ második időpont segítségével, amelyek így megadják az adott partíció egységét, jelen esetben a napot), és az egy konkrét napot jelölő időhatározó (például azon a napon, múlt szombaton) ennek a partíciónak egyetlen elemét, vagyis egyetlen intervallumot jelöl ki, amelynek a kezdő- és végpontjait jelöljük az adott rendezett pár elemeivel. Az adott $\eta$ temporális intervallumot jelölő kifejezés tehát függvényként az adott partíció egy elemének kezdőpontjához rendeli hozzá annak végpontját.

SZT2: Ha $\mathrm{R}_{\mathrm{T}}$ egy $\mathrm{n}$-argumentumú temporális predikátum, akkor a jelölete a következőképp adható meg:

$$
\left[\left[\mathrm{R}_{\mathrm{T}}\right]\right] \subseteq \mathrm{T}^{\mathrm{n}}
$$

SZT3: Ha $\mathrm{D}_{\mathrm{T}}$ egy temporális determináns és $\eta$ egy temporális intervallumot jelölő kifejezés, akkor $\mathrm{D}_{\mathrm{T}}(\eta)$ egy temporális kvantor, amelynek a jelölete a következőképp adható meg:

$$
\left[\left[\mathrm{D}_{\mathrm{T}}(\eta)\right]\right]=\left[\left[\mathrm{D}_{\mathrm{T}}\right]\right]([[\eta]])
$$

SZT4: Ha $\mathrm{Q}_{\mathrm{T}}=\mathrm{D}_{\mathrm{T}}(\eta)$ egy kvantor és $\gamma$ egy temporális intervallumot jelölő kifejezés, akkor $\mathrm{Q}_{\mathrm{T} \gamma}$ jelölete egy igazságérték a következőknek megfelelően:

$$
\begin{array}{r}
{\left[\left[\mathrm{Q}_{\mathrm{T} \gamma}\right]\right]=1 \text {, ha }[[\gamma]] \in\left[\left[\mathrm{Q}_{\mathrm{T}}\right]\right]} \\
0 \text {, ha }[[\gamma]] \notin\left[\left[\mathrm{Q}_{\mathrm{T}}\right]\right]
\end{array}
$$

Ez tehát azt jelenti, hogy egy tetszőleges állítás akkor és csak akkor igaz, ha az eseményidő által jelölt intervallum eleme azon intervallumok halmazának, amelyeket az 
aspektus + időhatározó (ami lehet implicit vagy explicit) egység denotál, ami a különböző aspektusok esetében különböző intervallumhalmazokat jelent.

SZT5: Minden temporális predikátum temporális intervallumot jelölő kifejezés.

SZT3 alapján tehát ha ASP egy temporális determináns, és $\eta$ egy $\langle\tau, \tau\rangle$ típusú, temporális intervallumot jelölő kifejezés, akkor:

$£ 16 \mathrm{Q}_{\mathrm{T}}:=[[\operatorname{Asp}(\eta)]]=[[\operatorname{Asp}]]([[\eta]])$, ahol Asp $\langle\langle\tau, \tau\rangle,\langle\tau, \tau\rangle, t\rangle$ típusú kifejezés, ami az $\eta\langle\tau, \tau\rangle$ típusú kifejezéssel alkot egy $\langle\langle\tau, \tau\rangle, t\rangle$ típusú, temporális általánosított kvantorként interpretálható kifejezést.

Vagyis az aspektus - mint temporális determináns - interpretációja a modellben egy olyan függvény, amely argumentumként veszi fel a T-n értelmezett rendezési reláció egy eleme által meghatározott részhalmazát a T-nek, vagyis az időhatározó által jelölt időintervallumot (a referenciaidőt), létrehozva így a temporális általánosított kvantort, ami a fenti példamondat esetében a következő: $\mathrm{Q}_{\mathrm{T}}=[[\operatorname{ASP}($ múlt szombaton $)]]$. Tehát az aspektus egy olyan függvény, amely a temporális univerzum egy részhalmazához (iᄃT) rendeli hozzá a temporális univerzum részhalmazainak egy halmazát.

Továbbá, SZT4 alapján ha $\mathrm{Q}_{\mathrm{T}}:=[[\mathrm{ASP}(\mathrm{Adv})]]$ egy temporális általánosított kvantor, és $\gamma$ egy $\langle\tau, \tau\rangle$ típusú, temporális intervallumot jelölő kifejezés, akkor az $\operatorname{ASP}(\mathrm{Adv})\langle\langle\tau, \tau\rangle, t\rangle$ típusú nyelvi kifejezésnek megfeleltetett $\mathrm{Q}_{\mathrm{T}}$ általánosított kvantor egy függvény - $\left(\mathrm{Q}_{\mathrm{T}}\right)(\gamma)$ - ami argumentumaként veszi fel a $\gamma\langle\tau$, $\tau\rangle$ típusú kifejezés által

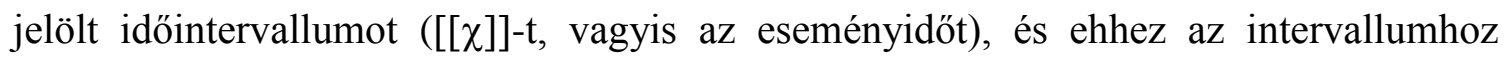
rendel igazságértéket. Tehát egy $\mathrm{Q}_{\mathrm{T}}$ temporális általánosított kvantor denotációja megadható időintervallumok halmazaként. 
$[[\operatorname{ASP}($ múlt szombaton $)(\chi)]]=1$, ha $[[\chi]] \in[[\operatorname{ASP}($ múlt szombaton $)]]$, egyéb esetben 0 .

Ha az aspektusnak a főnévi determinánsokhoz hasonló funkciót tulajdonítunk, és két rendezett halmaz közötti relációként definiáljuk, akkor az általánosított kvantorok elmélete alapján meg kell tudnunk adni azoknak a relációknak a jellegét, amelyeket az egyes aspektusok határoznak meg. Nézzük meg az objektumok esetében vizsgált determinánsok temporális megfelelöit!

A határozatlan névelőt tartalmazó általánosított kvantor, illetve a neki megfeleltethető temporális általánosított kvantor jelölete ((103) esetében) a következőképp adható meg a korábbi példamondatok esetében (lásd £18) ${ }^{58}$ :

$[[$ Néhány béka $]]=\{\mathrm{X} \subseteq \mathrm{U} \mid[[$ béka $]] \cap \mathrm{X} \neq \varnothing\}$

$£ 18\left[\left[\mathrm{ASP}_{\mathrm{o}}(\mathrm{Adv})\right]\right]=\left[\left[\mathrm{ASP}_{\mathrm{o}}(\right.\right.$ múlt szombaton $\left.\left.)\right]\right]=\{\mathrm{j} \subseteq \mathrm{T} \mid[[$ múlt szombaton $]] \circ \mathrm{j} \neq \emptyset\}$

A határozatlan névelőnek megfeleltetendő temporális determináns - vagyis aspektus jelentésében tehát az szerepel, hogy a referenciaidő által jelölt intervallumnak (mint rendezett halmaznak) és az eseményidő által jelölt intervallumnak (mint rendezett halmaznak) legyen közös eleme, vagyis a két intervallum átfedési relációban legyen egymással. Partee (1984) (lásd 6.3.1. fejezet) és Kearns (1991) (lásd 5.2.1. fejezet) alapján azt feltételezzük, hogy ez a perfektív aspektust határozza meg. A 10. ábrán látható reláció szemlélteti a (103) mondat perfektív olvasatában megfogalmazott állítás igazságfeltételeit:

$[[\mathrm{Adv}]]=[[$ múlt szombaton $]]=\mathrm{i}, \quad \mathrm{i} \subseteq \mathrm{T}, \quad \mathrm{i}$ jelölése: $\left\langle\mathrm{t}^{\prime}, \mathrm{t}^{\prime}\right\rangle$

$[[\chi]]=\operatorname{tr}[[$ Aurél vitorlázik $]]=\mathrm{j}, \quad \mathrm{j} \subseteq \mathrm{T}, \quad \mathrm{j}$ jelölése: $\left\langle\mathrm{t}{ }^{\prime}, \mathrm{t}^{\prime},{ }^{\prime}\right\rangle$

\footnotetext{
${ }^{58}$ Az aspektus általános definíciója után most az egyes aspektusokat eltérö alsó indexszel különböztetem meg, a reláció jellegére némileg utalóan ( o: overlap, p: part, s: singleton)
} 


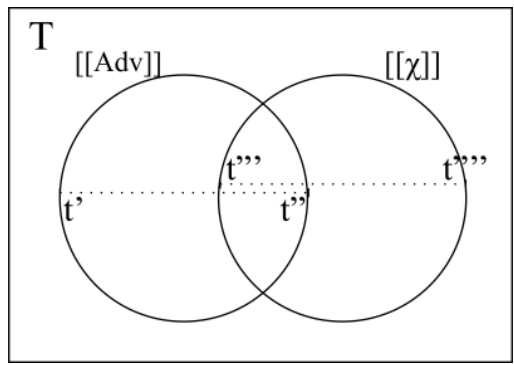

10. ábra

Az univerzális determinánst tartalmazó általánosított kvantor, illetve a neki megfeleltethető temporális általánosított kvantor jelölete a következőképp adható meg (lásd £19):

$[[$ minden béka $]]=\{\mathrm{X} \subseteq \mathrm{U} \mid[[$ béka $]] \subseteq \mathrm{X}\}$

$£ 19\left[\left[\operatorname{ASP}_{\mathrm{p}}(\mathrm{Adv})\right]\right]=\left[\left[\mathrm{ASP}_{\mathrm{p}}(\right.\right.$ múlt szombaton $\left.\left.)\right]\right]=\{\mathrm{j} \subseteq \mathrm{T} \mid[[$ múlt szombaton $]] \subseteq \mathrm{j}\}$

Az univerzális determinánsnak megfeleltethető temporális determináns esetében tehát a referenciaidő által jelölt intervallum az eseményidő által jelölt intervallumnak a részintervalluma (lásd 11. ábra). ${ }^{59}$

$[[\mathrm{Adv}]]=[[$ múlt szombaton $]]=\mathrm{i}, \quad \mathrm{i} \subseteq \mathrm{T}, \quad \mathrm{i}$ jelölése: $\left\langle\mathrm{t}^{\prime}, \mathrm{t}^{\prime}\right\rangle$

$[[\chi]]=\operatorname{tr}[[$ Aurél vitorlázik $]]=\mathrm{j}, \quad \mathrm{j} \subseteq \mathrm{T}, \quad \mathrm{j}$ jelölése: $\left\langle\mathrm{t}^{\prime},{ }^{\prime}, \mathrm{t}^{\prime,},{ }^{\prime}\right\rangle$

\footnotetext{
${ }^{59}$ A fönévi tartományban az univerzális determináns üres köznévi denotáción is értelmezve van, ezért az univerzális temporális determinánshoz kapcsolódó ábrában (lásd 11. ábra) nem tüntetek föl semmilyen intervallumot az időhatározó jelöleteként.
} 


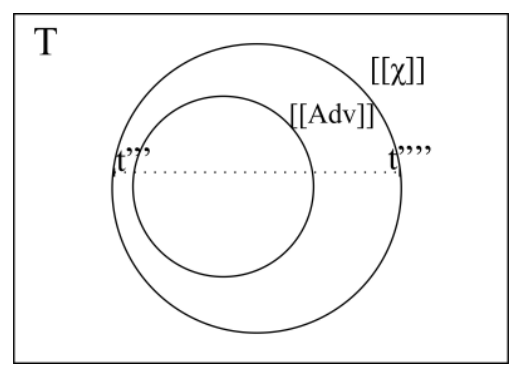

11. ábra

A határozott névelőt tartalmazó általánosított kvantor, illetve a neki megfeleltethető temporális általánosított kvantor jelölete a következőképp adható meg (lásd £20):

$[[$ A béka $]]=\{\mathrm{X} \subseteq \mathrm{U} \mid[[$ béka $]]=\{\mathrm{u}\}, \mathrm{u} \in \mathrm{X}\}$

$£ 20\left[\left[\mathrm{ASP}_{\mathrm{S}}(\mathrm{Adv})\right]\right]=\left[\left[\mathrm{ASP}_{\mathrm{s}}(\right.\right.$ múlt szombaton $\left.\left.)\right]\right]=\{\mathrm{j} \subseteq \mathrm{T} \mid[[$ múlt szombat $]]=\mathrm{i}, \mathrm{i} \subseteq \mathrm{j}\}$

A határozott névelőnek megfelelő temporális determináns jelentése alapján a referenciaidő által jelölt i intervallum részintervalluma kell legyen az eseményidő által jelölt $\mathrm{j}$ intervallumnak.

$[[\mathrm{Adv}]]=[[$ múlt szombaton $]]=\mathrm{i}, \quad \mathrm{i} \subseteq \mathrm{T}, \quad \mathrm{i}$ jelölése: $\left\langle\mathrm{t}^{\prime}, \mathrm{t}^{\prime}{ }^{\prime}\right\rangle$

$[[\chi]]=\operatorname{tr}[[$ Aurél vitorlázik $]]=\mathrm{j}, \quad \mathrm{j} \subseteq \mathrm{T}, \quad \mathrm{j}$ jelölése: $\left\langle\mathrm{t}^{\prime},{ }^{\prime}, \mathrm{t}^{\prime},{ }^{\prime}\right\rangle$

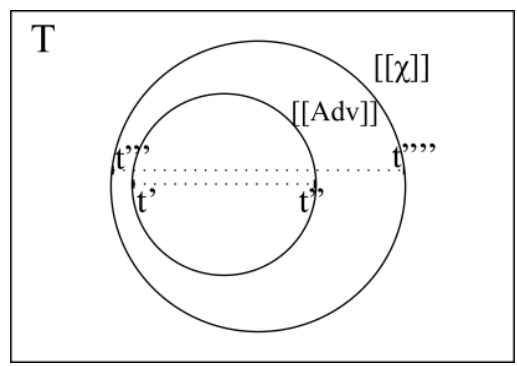

12. ábra 
Láthatjuk, hogy a megadott formális keretben mindhárom vizsgált főnévi tartománybeli determinánsnak: a határozatlan névelőnek, az univerzális determinánsnak és a határozott névelőnek is megadható a temporális megfelelöje. A következőkben azt fogom megvizsgálni, hogy az így megadott temporális determinánsokkal valóban azonosíthatóak-e a feltételezett aspektusok: a perfektív és - különösen - a progresszív.

\subsection{Az aspektusok determinánsi jellemzői}

Ha feltételezzük, hogy az aspektus a főnévi determinánsokhoz hasonló szerepet tölt be a temporális tartományban, vagyis tekinthető temporális determinánsnak, akkor feltételezhető, hogy a monotonitási tulajdonságok és az általános determinánsi tulajdonságok is ugyanúgy megvannak az aspektusnak megfeleltethető temporális determinánsok esetében, mint a fönévi determinánsoknál. Kiemelve a progresszív aspektust, mint a dolgozat fó tárgyát: mivel a nyelvi példák azt mutatták, hogy a progresszív aspektusú mondatban megjelenő időhatározóknak teljesíteniük kell az unicitás feltételét (lásd 4.2. fejezet), továbbá Kearns (1991) szerint a progresszív igeidő a határozott névelő segítségével jellemezhető (lásd 5.2.1. fejezet), a progresszív temporális determináns vizsgálatánál ugyanazon tulajdonságok kimutathatóságára számítunk, mint a határozott névelős főnévi csoportok esetében. Nézzük először a monotonitást!

\subsubsection{Az aspektusok monotonitása}

A monotonitás fogalmát és az egyes fajtáit változatlannak tekintem (lásd 5.1.1. fejezet), csupán a temporális determinánsokra alkalmazom. 
Tegyük fel, hogy $i=[[A d v]], j=\operatorname{tr}([[\varphi]])$, ahol tr a mondatgyök $(\varphi)$ által denotált esemény temporális nyomát megadó függvény. Akkor monoton egy $D_{T}$ temporális determináns, ha az argumentumaként álló $i$ vagyj intervallum bövitése vagy szükitése nem változtat a mondat igaz értékén. Az elöbbi esetben növekvö, az utóbbiban csökkenö monotonitású a $D_{T}$.

Most nézzük meg, hogy a tárgyalt temporális determinánsokat tartalmazó, vagyis a perfektív és progresszív aspektusú mondatok milyen következtetési sémát mutatnak. A baloldali monotonitást az időhatározó által jelölt intervallum bővítésével, illetve szükítésével teszteljük:

M13) i $\subset$ i’: Múlt szombaton futottam egy órát. $\Rightarrow$ Múlt héten futottam egy órát.

M14) i’ $\subset$ i: Múlt szombaton futottam egy órát. $* \Rightarrow$ Múlt szombat reggel futottam egy órát.

Ha igaz, hogy múlt szombaton futottam egy órát, akkor abból következik, hogy múlt héten futottam egy órát, tehát az i intervallum bővítése után is igaz marad a mondat. Az i intervallum szükítése során azonban megváltoznak a következtetési tulajdonságok, mert a bal oldali mondat igazsága nem feltétlenül vonja maga után a jobb oldali mondat igazságát. Egy olyan modellben például, amelyben múlt szombaton csak este futottam, a következtetés jobb oldalán álló mondat hamis lesz. Mivel az i intervallum szükítése során a mondat igazsága megváltozhat, de a bővítése során nem, a perfektív aspektus balról monoton növekvő determinánsként viselkedik. Nézzük a jobb oldali monotonitást:

M15) j $\subset$ j’: Múlt szombaton futottam egy órát. $* \Rightarrow$ Múlt szombaton futottam két órát. M16) j’ $\subset$ j: Múlt szombaton futottam egy órát. $\Rightarrow$ Múlt szombaton futottam fél órát.

Az eseményidő által jelölt $\mathrm{j}$ intervallum bővítése esetén a következtetés nem helyes, mert abból, hogy igaz, hogy szombaton futottam egy órát, nem következik, hogy 
futottam volna két órát. Viszont ha szükítjük a j intervallumot, akkor a bal oldali mondat igazságából már következik a jobb oldali mondat igazsága. Mivel a j intervallum bővítése mellett nem őrződik meg a mondat igazsága, de a szükítése mellett igen, a perfektív aspektus jobbról monoton csökkenő. Összehasonlítva a főnévi tartománybeli egy/néhány determináns és a perfektív aspektus esetében vizsgált következtetéseket, várakozásunktól eltérően más következtetési sémát mutatnak, vagyis eltérő monotonitási tulajdonságokkal rendelkeznek: míg a határozatlan névelő balról is és jobbról is monoton növekvő, a perfektív temporális determináns balról monoton növekvő, jobbról monoton csökkenő. Most nézzük meg, hogy a progresszív aspektus a neki megfeleltetett határozott névelő monotonitási tulajdonságait mutatja-e!

M17) iᄃ i’: Múlt szombaton épp vitorláztam. ${ }^{*} \Rightarrow$ Múlt héten épp vitorláztam.

M18) i’ $\subset$ i :Múlt szombaton épp vitorláztam. $\Rightarrow$ Múlt szombaton reggel épp vitorláztam.

Nézzük először a baloldali monotonitást! Az időhatározó által jelölt referenciaidő i intervallumának bővítése esetén, vagyis amikor tágabb referenciaidőt adunk meg, a következtetés nem állja meg a helyét, tehát a progresszív aspektus nem bal monoton növekvő. Ha viszont szükítjük az $i$ intervallumot, a baloldali mondat igazságából következik a jobb oldali mondat igazsága, ami azt mutatja, hogy a progresszív aspektus temporális determinánsként bal monoton csökkenő. Várakozásunktól eltérően azonban ez nem a határozott névelő következtetési sémáját mutatja, hiszen a határozott névelő balról nem monoton (lásd 5.1.1. fejezet) Nézzük meg a jobb oldali monotonitást is:

M19) $\mathrm{j} \subset \mathrm{j}$ ': Múlt szombaton épp vitorláztam. $\Rightarrow$ Múlt szombaton épp vízen voltam.

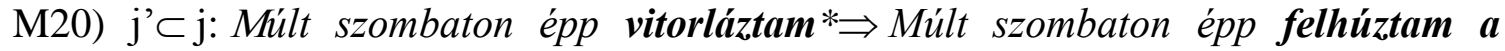
vitorlát. 
Ha a j intervallumot bővítjük, a mondat igaz értéke megmarad. Ha azonban szükítjük a j intervallumot, akkor nem áll fenn a logikai következmény reláció, hiszen abból, hogy vitorláztam, nem következik, hogy egész idő alatt a vitorlát húztam föl, könnyen lehet, hogy az csak egy részét töltötte ki a szombati napnak. Mivel a j intervallum szükítésével nem őrződik meg a mondat igaz értéke, a bővítésével viszont igen, a progresszív aspektus jobbról monoton növekvő temporális determináns.

Összehasonlítva a főnévi tartománybeli határozott névelőt és a progresszív aspektust jellemzö következtetési sémát, azt tapasztaljuk, hogy mindkettő jobb monoton növekvő, a baloldali monotonitást tekintve viszont eltérőek. A határozott névelő balról nem monoton, mert csak egyelemü köznévi denotáción van értelmezve, aminek következtében se nem bővíthető, se nem szükíthető a köznév által jelölt halmaz, mert az unicitásnak teljesülnie kell.

A temporális tartományban az időhatározó által jelölt rendezett halmaz, vagyis intervallum unicitásának kell teljesülnie ahhoz, hogy a feltételezésünk helyes legyen. Láttuk, hogy a nyelvi példák a 4.2. fejezetben azt mutatták, hogy a progresszív aspektusú mondatban csak olyan időhatározó jelenhet meg, amelyik teljesíti ezt az unicitási feltételt, mert egyetlen konkrét intervallumot jelöl. A 6.2. fejezetben megadott modellben Kamp - Schiehlen (2001) szintén arra a megállapításra jut, hogy a naptári időhatározói kifejezések (például kedden délután, vagy akár múlt szombaton) jelölete egyetlen intervallum, azaz teljesül az unicitás, vagyis a szemantikai státuszuk a határozott leírásokéval azonos. A progresszív aspektus - annak ellenére, hogy a benne megjelenő időhatározó teljesíti az unicitás feltételét - monotonitási szempontból mégis az univerzális determinánshoz hasonlít.

A különbség feltehetően a modelljeik különbségével magyarázható. Ha az objektumok esetében a köznévi denotáció egyetlen objektumot tartalmaz - ahogy azt a határozott névelö szemantikai tartalma megköveteli -, akkor azt nem tudjuk sem bővíteni, sem szűkíteni. A temporális tartományban az időhatározó denotációját azonban hiába adjuk meg Kamp - Schiehlen (2001) alapján egy adott partíció egyetlen elemeként - vagy a T halmazon értelmezett reláció egyetlen elemeként, egy rendezett párként (lásd 
6.2. fejezet) - az mégis egy olyan rendezett halmazt (egy időintervallumot) jelöl, ami végtelenül osztható, tehát többelemü halmazként viselkedik.

Monotonitásukat tekintve tehát sem a perfektív aspektus, sem a progresszív aspektus nem a várakozásunknak megfelelő viselkedést mutatta, mert a perfektív aspektus által mutatott tulajdonságok nem egyeznek a határozatlan névelőéivel, a progresszív aspektus által mutatottak pedig nem egyeznek a határozott névelö által mutatottakkal, hanem az univerzális determinánshoz hasonlóak. A vizsgálat alapján azonban megállapíthatjuk, hogy monotonitási szempontból a perfektív és a progresszív aspektus egymás inverzei: $\uparrow \mathrm{PERF} \downarrow, \downarrow P R O G \uparrow$.

\subsubsection{Az aspektusok és az általános determinánsi tulajdonságok: a konzervativitás}

Az aspektusokat temporális determinánsnak tekintve azt is feltételezhetjük, hogy az egyes aspektusok a fónévi tartományból ismert általános determinánsi tulajdonságok tekintetében hasonlóak ahhoz a determinánshoz, amelynek megfeleltettük őket. Nézzük a korábbi példamondatunkat, ami lehet perfektív és progresszív olvasatú is:

103. Múlt szombaton Aurél (éppen) vitorlázott. ${ }^{60}$

Mivel a korábban bemutatott természetes nyelvi determinánsok mindegyike kiterjeszthető és konzervatív, a határozatlan névelőnek megfeleltetett perfektív, és a határozott névelőnek megfeleltetett progresszív aspektusról is feltételezhetjük, hogy kiterjeszthető és konzervatív. Mivel az aspektusok szempontjából a konzervativitásnak lesz igazán jelentősége, ezért csak ez utóbbit vizsgálom a temporális tartományban. A

\footnotetext{
60 A két értelmezés esetében más-más temporális általánosított kvantorunk van annak ellenére, hogy az időhatározó alakilag és jelöletében is mindkét esetben azonos (lásd még 6.1. fejezet), hiszen a két esetben a temporális általánosított kvantorok determinánsai eltérő tulajdonságokkal rendelkező függvények (lásd 6.4. fejezet).
} 
konzervativitás temporális definíciója értelmében a mondat igazsága szempontjából az eseményidő által jelölt j intervallumnak csak az a részintervalluma számít, amelyik az i referenciaidőbe esik:

Tegyük fel, hogy $i=[[A d v]], j=\operatorname{tr}([[\varphi]])$, ahol tr a mondatgyök $(\varphi)$ által denotált esemény temporális nyomát megadó függvény. Egy temporális determináns akkor konzervativ, ha minden $\varphi$-re és Adv-ra:

$$
(\operatorname{ASP}([[\operatorname{Adv}]]))(\operatorname{tr}([[\varphi]])) \Leftrightarrow(\operatorname{ASP}([[\operatorname{Adv}]]))([[\operatorname{Adv}]] \circ(\operatorname{tr}([[\varphi]])))
$$

A (103) példamondat esetében ez a következőt jelenti:

$(\mathrm{ASP}([[$ múlt szombaton $]]))([[\chi]]) \Leftrightarrow(\operatorname{ASP}([[$ múlt szombaton $]]))([[$ múlt szombaton $]] \circ[[\chi]])$

A határozatlan névelőnek megfeleltetett temporális determináns jelentésében (lásd £18) az szerepel, hogy a referenciaidő és az eseményidő által jelölt intervallumok átfedjék egymást. A perfektív aspektus olvasatú Múlt szombaton Aurél vitorlázott mondat esetében ez azt jelenti, hogy a perfektív mondat igazságának szempontjából az eseményidő által jelölt intervallumnak csak az a része játszik szerepet, amelyik a referenciaidő által jelölt intervallummal átfedésben van, vagyis beleesik a referenciaidőbe. Egy olyan modellben például, ahol Aurél szombaton délben kezdett vitorlázni, és még szombaton be is fejezte, a mondat igaz. De ugyanígy igaz, ha csak szombat este kezdett el vitorlázni, és hétfőn délelőtt fejezte be, vagy éppen szerdán kezdett el vitorlázni, és szombaton délben fejezte be. Ez azt mutatja, hogy az eseményidőnek csak az a részintervalluma számít a mondat igazságát tekintve, amelyet az alábbi ábrán a $\langle\mathrm{t} ",, t ”\rangle$-nek megfelelő intervallum jelöl. 


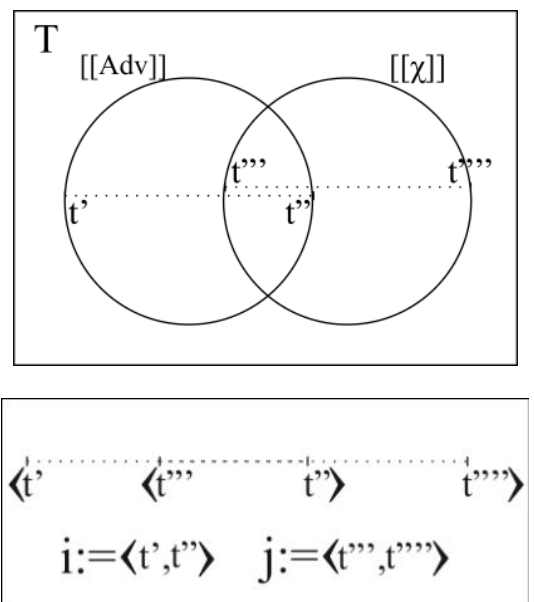

13. ábra

Vagyis a perfektív aspektusú mondat esetében az eseményidőnek azon részintervalluma, amelyik nem része a referenciaidőnek (ilyen a $\left\langle\mathrm{t}^{\prime}, \mathrm{t}^{\prime \prime}\right\rangle$ és a $\left.\left\langle\mathrm{t}^{\prime}, \mathrm{t}^{\prime \prime},\right\rangle\right)$, irreleváns, tehát a perfektív aspektus, akárcsak a határozatlan névelö, konzervatív temporális determináns.

A Múlt szombaton Aurél (éppen) vitorlázott példamondat progresszív olvasata esetén egy olyan modellben, ahol Aurél a szombati napot teljes egészében vitorlázással töltötte, a mondat igaz, egy olyanban viszont, ahol a vitorlázás nem vette igénybe az egész szombati napot, akkor hamis. Egy olyan modellben, ahol Aurél már szerdán kezdte a vitorlázást, és egész szombaton vitorlázott, a mondat igaz, és akkor is igaz, ha nemcsak egész szombaton vitorlázott, hanem még azon túl is folytatta. Épp ez a temporális keret olvasat. A határozott névelő jelentését megadó formula alapján (lásd $£ 20)$ a referenciaidő által jelölt intervallum részintervalluma kell legyen az eseményidő által jelölt intervallumnak. Vagyis a referenciaidőnek nem lehet olyan részintervalluma, amely nem részintervalluma az eseményidőnek is, egy ilyen modellben hamis a (103)-as mondat progresszív olvasatban. Olyan feltételt azonban nem tartalmaz a formula, amely az eseményidő azon részére vonatkozik, amely a referenciaidőnek nem része.

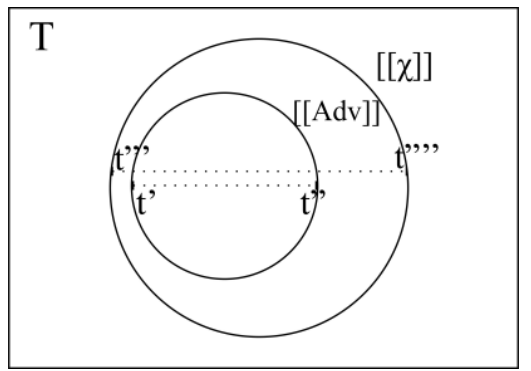




$$
\begin{gathered}
\langle\mathrm{t}, \cdots \\
\mathrm{i}:=\langle\mathrm{t}, \mathrm{t},\rangle \quad \mathrm{j}:=\left\langle\mathrm{t}, \mathrm{t}^{\prime}, \mathrm{t}^{\prime \prime \prime}\right\rangle
\end{gathered}
$$

14. ábra

Mivel a (103)-as mondat progresszív olvasatban igaz akkor is, ha az esemény nem tart a referenciaidőt megelőzően vagy követően, és akkor is, ha tart, megállapítható, hogy a mondat igazsága szempontjából csak a referenciaidő által jelölt intervallum releváns amit a 14. ábrán a $\left\langle\mathrm{t}^{\prime}, \mathrm{t}^{\prime}\right\rangle-$-nek megfelelő intervallum jelöl -, az azon kívül eső intervallum(ok) irrelevánsak. Ezek alapján a progresszív aspektusról is megállapítható, hogy konzervatív temporális determináns. 


\section{A progresszív aspektus és a megszakítás problémája}

Nézzük meg, hogy a bemutatott megközelítés milyen eredménnyel jár a progresszív aspektusú mondatok esetében felmerülő megszakítás problémájára nézve! Ahogy a bevezetőben szó volt róla, a megszakítás problémája azért merül fel, mert a progresszív mondat igazságfeltételeit az alapján próbálták formális eszközökkel megadni, hogy Jespersen a progresszív mondat jelentését a temporális keret olvasat megjelenésével azonosította. A progresszív aspektus hagyományos definíciói (például az (1)-ben adott, itt megismételve, vagy (2), (3)) a progresszív kiértékelési idejének megfeleltetett $t$ intervallumon túl feltételeznek egy azt magába foglaló $I$ intervallumot, amellyel az esemény folytatására hivatkoznak.

(1) [PROGa] akkor és csak akkor igaz t intervallumnál, ha létezik olyan I intervallum, amelyre teljesül, hogy $t$ valódi részhalmaza I-nek, $t$ nem záró intervalluma I-nek, és $\alpha$ igaz I-nél. ${ }^{61}$

Az esemény megszakítása esetén azonban nincs a definíciónak megfelelő I intervallum, hiszen az esemény nem folytatódik, a progresszív mondat mégis igaz lehet (lásd korábbi (17), itt (104)) Azt is láttuk, hogy a megszakítás problémája telikus és atelikus eseményeket kifejező predikátumok esetében egyaránt megjelenik (lásd korábbi (14), itt (105)). A megszakítás problémája tehát az a jelenség, hogy egy progresszív mondat igaz lehet úgy is, hogy a folyamatban levő esemény megszakad, és nem is folytatódik.

104. Mary was crossing the street, when the truck hit

Mary átkel-MÚLT PROG az utca amikor a teherautó elüt-SMPLE PAST őt 'Mary épp ment át az úton, amikor elütötte a teherautó.'

${ }^{61},[\mathrm{PROG} \alpha]$ is true at $\mathrm{t}$ iff there is an interval $\mathrm{I}$ such that $\mathrm{t}$ is a proper subset of $\mathrm{I}, \mathrm{t}$ is not a final subinterval of I, and $\alpha$ is true at I." (Az idézetet Kearnstől vettem át: Kearns (1991), 35. oldal, ő Bennett-Partee (1978)-ként hivatkozik rá.) 
105. John was watching television when he fell

asleep.

John néz-MÚLT PROG tévé amikor ö esik-MÚLT álomban

'John épp tévét nézett, amikor elaludt.'

A dolgozatban bemutatott kutatás eredményei Parsons (1989) azon megállapítását támasztják alá, amely szerint a progresszív mondatok igazságfeltételeinek szempontjából csak a jelenben zajló események számítanak (ami múlt idejű mondat esetében a referenciaidőt jelenti.) Parsons megoldásának lényege, hogy az események és időintervallumok viszonyában a progresszív események inherens tulajdonságaként az intervallumokhoz való viszonyuk más, mint a nem progresszív eseményeké. A progresszív események a Hold viszonnyal jellemezhetők, míg a nem progresszívek a $C u l$ viszonnyal. Mivel azonban ezek a tulajdonságok az események inherens tulajdonságai, az adott megoldással elkerüli ugyan a kérdéses problémákat, magyarázó ereje meglehetősen kicsi.

A dolgozatban bemutatott megközelítés szerint az aspektus általánosságban egy olyan függvény, amely a temporális univerzum egy részhalmazához (a referenciaidő által jelölt intervallumhoz) a temporális univerzum részhalmazainak egy halmazát rendeli, ezen belül a progresszív aspektus pedig azon eseményidő-intervallumok halmazát, amelyeknek a referenciaidő a részintervalluma. A progresszív aspektust tehát a következőképpen definiálom:

$£ 23$

$$
[[P R O G]](A d v):=\{\mathrm{j} \subseteq \mathrm{T} \mid[[\mathrm{Adv}]]=\mathrm{i}, \mathrm{i} \subseteq \mathrm{j}\}
$$

A progresszív aspektust determináns-függvénynek tekintve értelmezhetőek rajta a főnévi determinánsokra is jellemző tulajdonságok. Megállapítottuk, hogy bal monoton csökkenő, jobb monoton növekvő és konzervatív temporális determináns.

A konzervativitásnak különös jelentősége van a progresszív aspektus esetében, mert annak következménye az, hogy a progresszív aspektusú mondat 
igazságfeltételeinek megadásában kizárólag a referenciaidő által jelölt intervallum releváns. A referenciaidő (lásd i) és eseményidő (lásd j) viszonyát progresszív mondat esetében az alábbi, korábbról megismételt ábra szemlélteti:

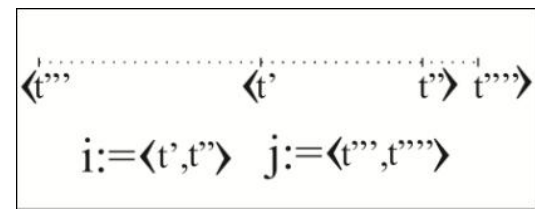

15. ábra

A konzervativitás következtében tehát minden olyan időintervallum irreleváns (lásd $\left\langle t^{\prime \prime}, t^{\prime}\right\rangle$ és $\langle t$ ", $t$ "'” $\left.\rangle\right)$, amely nem része a referenciaidő által jelölt intervallumnak. Ez azt jelenti, hogy a progresszív mondat igazságának szempontjából irreleváns a folyamatban lévő, de megszakadt esemény esetleges folytatásának eseményideje által jelölt

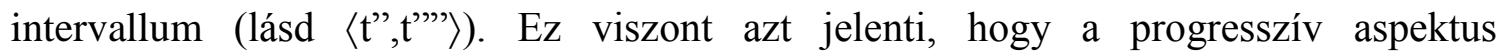
szemantikája (temporális vonatkozásban) nem tartalmazza a megszakadt esemény (esetleges) folytatását.

Kearns korábban bemutatott érvelésével egyetértve (lásd 2.2.2. fejezet) úgy gondolom, hogy a temporális keret olvasat megjelenése, vagyis hogy feltételezzük az esemény folytatódását, Grice mennyiségi maximájával magyarázható. Ugyanakkor újból hangsúlyozom, hogy a dolgozatban csak szükséges, de nem elégséges feltételekről van szó, hiszen a progresszív aspektus szemantikája nem merül ki a temporális tulajdonságainak megadásában.

A bemutatott megközelítés Parsons (1989) és Kearns (1991) megoldásához hasonlóan extenzionális keretek között marad, mert nem feltételez lehetséges világokat, és az aktuális világban sem feltételezi az esemény folytatását. Kearns ezt azzal oldja meg, hogy diszjunkciót alkalmaz a definíciójában (lásd 2.2.2. fejezet, (5) definíció) ${ }^{62}$, Parsons pedig a fent említett két tulajdonság (Hold, $\mathrm{Cul}$ ) feltételezésével. A dolgozatban bemutatott megoldás előnye ezekkel szemben az, hogy bármiféle új eszköz bevezetése

\footnotetext{
${ }^{62}$ [PROG $]$ ] akkor és csak akkor igaz t-nél, ha a igaz t-nél, vagy létezik olyan t', amelynek t részhalmaza, és a igaz t'-nél.
} 
nélkül, egy már meglévő, formálisan kidolgozott elmélet alkalmazásának logikai következményeként állapítható meg ugyanaz, vagyis hogy a progresszív aspektus definíciójában nem indokolt a folyamatban lévő esemény folytatására hivatkozni. 


\section{8. Összefoglalás}

A progresszív szemantikájával foglalkozó elméletek számára a két legjelentősebb probléma az imperfektív paradoxon és a megszakítás problémája. A dolgozatban csak a megszakítás problémájával foglalkoztam, tehát azzal, hogy egy progresszív aspektusú mondat igaz lehet, függetlenül attól, hogy az általa leírt, folyamatban lévő esemény kiteljesedik-e vagy megszakad. A megszakítás problémája azért jelenik meg a progresszív aspektusnak a dolgozatban hivatkozott - (például Bennett - Partee (1978), Dowty (1979), Landman (1992)) - definíciói esetében, mert a Jespersen által megfogalmazott temporális keret olvasatot próbálják megragadni.

Az említett problémákra született megoldási kísérleteket alapvetően két csoportba soroltam aszerint, hogy extenzionális vagy intenzionális keretben kívánják-e megoldani a megszakítás problémáját. Az intenzionális elméletek ezt lehetséges világok segítségével teszik úgy, hogy az esemény megszakadása esetén annak kiteljesedését az aktuális világból elérhető bizonyos lehetséges világokban feltételezik, az aktuális világban nem. Ilyen elméletek például Dowty (1979), Landman (1992) és Varasdi (2006). Bár jól megalapozott a motivációja az intenzionális elméleteknek, amelyek a progresszív szemantikáját a modalitás bevonásával adják meg, léteznek olyan megoldások, amelyek extenzionális keretben maradva egyszerübb megoldást javasolnak. Ilyen elméletek például Parsons (1989) és Kearns (1991).

A dolgozatban bemutatott kutatás eredményeképp az extenzionális megoldás mellett foglalok állást, egyetértve Parsons következő megállapításával (lásd 2.1.1. fejezet):

„Meggyöződésem, hogy csakis a jelenben zajló cselekvések azok, amik számítanak.” 
A dolgozatban olyan magyar progresszív mondatokat vizsgáltam, amelyekben a progresszív aspektusú tagmondat fömondati pozícióban van, és megjelenik bennük egy időhatározó. A progresszív mondatokban megjelenő időhatározó a referenciaidőt jelöli, azt az időintervallumot, amelyhez képest a mondatban leírt esemény progresszívként értelmeződik. A nyelvi példák azt mutatják, hogy a progresszív aspektusú mondat megszorítást tesz a benne megjelenő időhatározókra, mert csak olyan időhatározó megjelenését teszi lehetővé, amely egyetlen konkrét intervallumot jelöl. Ezeknek az időhatározóknak a szintaktikai és szemantikai vizsgálata azt mutatja, hogy a progresszív aspektusú mondatban az objektumot jelölő topikokhoz hasonlóan diskurzus topik szerepűek, ezért temporális topiknak tekintem őket.

A főnévi és igei (temporális) tartomány között megfigyelhető hasonlóságra számos utalás történt már a szakirodalomban, és ezt a megfigyelést a dolgozatban bemutatott vizsgálatok is alátámasztották. A dolgozat alapfeltevése az, hogy a progresszív mondatban megjelenő temporális topik ugyanúgy vizsgálható az általánosított kvantorok elméletével, mint az objektumokat jelölő főnévi kifejezések. A dolgozatban olyan tanulmányokat ismertetek (lásd 5.2. fejezet), amelyek valamilyen szempontból alátámasztják ezt a feltevést.

A temporális és objektum topikok közötti szintaktikai, szemantikai és ontológiai párhuzam, valamint az ismertetett szakirodalmi háttér alapján az általánosított kvantorok elméletét a dolgozatban megfogalmazom időintervallumokra vonatkoztatva. Ahogy az objektumok tartományában a fönévi csoportok denotációját tekinthetjük individuumhalmazok halmazának, úgy a temporális topik szerepét betöltő időhatározó denotációját intervallumhalmazok halmazának tekintem, vagyis általánosított kvantornak az időintervallumok halmazán.

Az általánosított kvantorként interpretálható kifejezések a fönévi tartományban egy determinánsból és egy halmazjelölő kifejezésből állnak, és egy predikátum kifejezéssel együtt alkotnak mondatot, amelyhez igazságértéket rendelhetünk. Az általánosított kvantorok elméletének temporális alkalmazásával megmutatom, hogy az aspektus és az időhatározó együttesen temporális általánosított kvantorként interpretálható kifejezést alkot, amelyben az aspektus determinánsi szerepet tölt be. Ez a 
dolgozat fö állítása. Mivel azonban nem köthető egyetlen nyelvi elemhez ez a szerep, egy üres kategóriát feleltetek meg neki.

A főnévi tartományban a determinánsokat két halmaz közötti relációnak, vagy ezzel ekvivalensen - függvénynek tekintjük, amelyeknek bizonyos tulajdonságai az általánosított kvantorok elméletében jól megragadhatóak. Ilyen tulajdonságok többek között a monotonitás, a kiterjeszthetőség és a konzervativitás. Ezeknek a tulajdonságoknak a kimutatásával támasztom alá, hogy az egyes aspektusok hasonlóak a főnévi determinánsokhoz, ezért indokolt az aspektusokat temporális determinánsnak tekinteni. A dolgozat tárgyának szempontjából elsősorban a progresszív aspektus determinánsi jellege releváns; megmutatom, hogy vizsgálhatók vele kapcsolatban a főnévi tartományból ismert determinánsi tulajdonságok, és a progresszív aspektus bal monoton csökkenő, jobb monoton növekvő, konzervatív, tehát valóban tekinthető temporális determinánsnak. Bár a progresszív aspektust a nyelvi példák és a dolgozatban alkalmazott temporális modell alapján is a határozott névelőnek feleltethetjük meg, a monotonitást tekintve a progresszív aspektus az univerzális detrerminánshoz hasonló.

A dolgozatban bemutatott kutatás eredményeképp a progresszív aspektus temporális determinánsként egy olyan függvénynek tekinthetö, amely a temporális univerzum egy részhalmazához (a referenciaidő által jelölt intervallumhoz) a temporális univerzum részhalmazainak egy halmazát rendeli: azon intervallumok halmazát, amelyeknek a referenciaidő a részintervalluma. Definíciója a következő:

\section{$[[$ PROG $]($ Adv $):=\{\mathbf{j} \subseteq \mathrm{T} \mid[[\mathrm{Adv}]]=\mathbf{i}, \mathbf{i} \subseteq \mathbf{j}\}$}

Az aspektusok esetében is kimutatható determinánsi tulajdonságok közül a konzervativitásnak különös jelentősége van a progresszív aspektus esetében, mert annak következményeképp megállapítható, hogy a progresszív aspektusú mondat igazságfeltételeinek megadásában kizárólag a referenciaidő által jelölt intervallum releváns. Ez azt jelenti, hogy irreleváns a folyamatban lévő, de megszakadt esemény esetleges folytatásának eseményideje által jelölt intervallum. Ez alapján a progresszív aspektus szemantikája (temporális vonatkozásban) nem tartalmazza a megszakadt 
esemény (lehetséges) folytatását, a temporális keret olvasat - a folytatás feltételezése Grice mennyiségi maximája alapján jelenik meg.

A dolgozatban adott megoldás extenzionális kereteken belül marad, ugyanakkor a bemutatott, szintén extenzionális megoldásokkal szemben előnye, hogy egy formálisan kidolgozott elmélet - az általánosított kvantorok elmélete - alkalmazásának logikai következményeként állapítja meg, hogy a progresszív aspektus definíciójában nem indokolt a folyamatban lévő esemény folytatására hivatkozni, ezért nagyobb a magyarázó ereje. 


\section{Felhasznált irodalom}

Bach, E. (1981): On Time, Tense, and Aspect: An Essay in English Metaphysics. in Peter Cole (ed.), Radical Pragmatics, New York: Academic Press, 63-81

Bach, E. (1986): The Algebra of Events. Linguistics and Philosophy 9 (1986): 516.Barwise, J. - Cooper, R. (1981): Generalized quantifiers and natural language. Linguistics and Philosophy 4: 159-219.

Bennett, M. - Partee, B. (1978): Toward the Logic of Tense and Aspect in English. Technical report, Indiana University Linguistics Club, Bloomington

Blackburn, P. (1994): Tense, Temporal Reference and Tense Logic, http://www.daogee.info/pdf/tense/1.pdf 1-15. old., letöltés ideje: 2012.06.26.nyomtatásban: Journal of Semantics 11. 53-101.

Carlson, G. (1977): Reference to Kinds in English. Dissertation.

Chomsky, N. (1975): Questions of Form and Interpretation, Mouton de Gruyter

Corazza, E. (2002): Temporal indexicals and temporal terms, Synthese 130: 441 - 460, Kluwer Academic Publishers

Dowty, D. (1979): Word Meaning and Montague Grammar: The Semantics of Verbs and Times in Generative Semantics and in Montague's PTQ. Dordrecht: Reidel.

Dowty, D. (1982): Tenses, Time Adverbs, and Compositional Semantic Theory. Linguistics and Philosophy 5. 23-55. oldal

É. Kiss, K. (1992): Az egyszerü mondat szerkezete in Kiefer F. (szerk.), Strukturális magyar nyelvtan 1. Mondattan. Akadémiai Kiadó, Budapest, pages79-179.

É. Kiss, K. - Kiefer, F. - Siptár, P. (1998): Új magyar nyelvtan. Osiris Kiadó, Budapest, 1-184. oldal

Gécseg, Zs. (2006): Topic, Logical Subject \& Sentence Structure in Hungarian. Acta Linguistica Hungarica 53. 139-174. oldal

Gendler-Szabó, Z. (2004): On the Progressive and the Perfective. Noûs, 2004

Glasbey, S. R. (2005): A "temporal topic interval" analysis of the English perfect. Accepted as an alternate for presentation at the LAGB Satellite Workshop on Perfectivity and Telicity, Fitzwilliam College, Cambridge, September 3-4. 2005.

Gyuris, B. - Varasdi, K. - Maleczki, M. (2008): Formális szemantika. Második, Javított kiadás. Szeged, JATEPress 
Heusinger Von, K. (2001): Information Structure and Discourse Semantics. The Prague Bulletin of Mathematical Linguistics 73-74, 13-32.

Jespersen, O. (1932): A Modern English Grammar on Historical Principles Part IV, originally published by Carl Winter, Heidelberg, later vols. by Ejnar Munksgard, Copenhagen and George Allen \& Unwin, London

Kálmán, L. (1985): Word order in neutral sentences. In: I. Kenesei (ed.), Approaches to Hungarian 1, JATE Szeged, 1985. pp. 13-23.

Kamp, H. - Schiehlen, M. (2001): Temporal Location in Natural Language, in Hans Kamp \& Uwe Reyle (eds.), How we say WHEN it happens. Contributions to the theory of temporal reference in natural language, Max Niemeyer Verlag, Tübingen

Kamp, H. - van Genabith, J — Reyle, U. (2004): DRT, Dov Gabbay: Handbook of Phil. Logic, 15. köt.

Kaplan, D. (1977): Demonstratives. In. Almog - Perry - Wettstein (szerk.): Themes from Kaplan. 1989. Oxford University Press. New York

Kearns, K. S. (1991): The Semantics of the English Progressive, Dissertation, Dept.of Linguistics and Philosophy, MIT

Keenan, E. L. (1987): A semantic definition of 'Indefinite NP', In: Eric Reuland and Alice ter Meulen (szerk.): The representation of (In)definitess 286-317. oldal, Cambridge, Mass.: MIT Press

Kiefer, F. (1992a): Aspect and conceptual structure: the progressive and the perfective in Hungarian. Fügungspotenzen (Studia Grammatica 34) (szerk.): I. Zimmermann és A. Strigin, 89-110. Berlin, Akademie Verlag

Kiefer, F. (1992b): Az aspektus és a mondat szerkezete. Kiefer (szerk.): Strukturális magyar nyelvtan I. Mondattan, Akadémiai Kiadó, Budapest, 797-886.

Kiefer, F. (1994): Aspect and syntactic structure. In: F. Kiefer - K. É. Kiss, (eds.). The Syntactic Structure of Hungarian, Academic Press, New York 1994, Pages 415464.

Kiefer, F. (2006): Aspektus és akcióminöség különös tekintettel a magyar nyelvre (Aspect and aktionsart in Hungarian). Budapest, Akadémiai Kiadó.

Kiefer, F. (2009): Types of temporal adverbials and the fine structure of events in: É. Kiss, Katalin (ed.): Adverbs and Adverbial Adjuncts at the Interfaces, Berlin, New York (Mouton de Gruyter), Pages 247-268 
Kratzer, A. (1995): Stage-Level and Individual-Level Predicates. In G. Carlson and J. Pelletier (eds.): The Generic Book. Chicago (Chicago University Press), 1995, 125175. To be reprinted in James Higginbotham (ed.) Language and Cognition. Oxford (Basil Blackwell).

Krifka, M. (1989): Nominal Reference, Temporal Constitution and Quantification in Event Semantics, In R. Bartsch, J. v. Benthem és van Emde Boas (szerk.) Semantics and Contextual Expression, Foris, Dordrecht, 75-115.

Krifka, M. (2007): Basic notions of information structure. In C. Fery and M. Krifka (eds.), Interdisciplinary Studies of Information Structure 6, Potsdam, 2007. See also edited volume. Also in Acta Linguistica Hungarica 55 (2008), 243-276.

Lambrecht, K (1994): Information Structure and Sentence Form: topic, focus and the mental representations of discourse referents. Cambridge Studies in Linguistics 71. Cambridge University Press

Landman, F. (1989): Groups, I, Linguistics and Philosophy 12. 559-605. oldal

Landman, F. (1992): The progressive. in: Natural Language Semantics, 1.1, 1-32 oldal.

Leech, G. N. (1969): Towards a Semantic Description of English, London: Longman pp. 277. oldal

Link, G. (1983): The Logical Analysis of Plurals and Mass Terms: A Lattice-Theoretical Approach. In: R. Bauerle, Chr. Schwarze és A. v. Stechow (szerk.) Meaning, Use and Interpretation of Language, de Gruyter, Berlin, 302-323.

Link, G. (1997): Algebraic Semantics in Language and Philosophy, Standford, CSLI Publications, Center for the Study of Language and Information, Leland Stanford Junior University, 432 oldal

Maleczki, M. (2004): The semantic analysis of thetic judgements, The Eighth Symposium on Logic and Language. Preliminary Papers, 107-118. oldal, Debrecen

McCoard, R. (1978): The English Perfect: Tense-Choice and Pragmatic Inferences, North Holland, Amsterdam

Mittwoch, A. (1988): Aspects of English aspect: On the interaction of perfect, progressive and durational phrases. Linguistics and Philosophy 11. 203-254.

Moens, M. - Steedman, M. (1988): Temporal ontology and temporal reference. Computational Linguistics, Volume 14, Number 2.

Montague, R. (1969): On the nature of certain philosophical entities, In: The Monist 
Montague, R. (1973):The Proper Treatment of Quantification in ordinary English In Patrick Suppes, Julius Moravcsik \& Jaakko Hintikka (eds.), Approaches to Natural Language. Dordrecht

Mostowski, A. (1957): "On a generalization of quantifiers", Fundamenta Mathematicae Vol. 44, No. 1, ss. 12-36.

Parsons, T. (1989): The Progressive in English: Events, States and Processes. Linguistics and Philosophy 12. 213-241.

Partee, B. H. (1984): Nominal and temporal anaphora, Linguistics and Philosophy 7, 243-286.

Piñón, C. J. (1995): Around the Progressive in Hungarian in Kenesei (szerk.): Approaches to Hungarian, Vol. 5., Szeged

Portner, Paul (2003): The (temporal) semantics and (modal) pragmatic of the perfect. Linguistics and Philosophy 26: pp 459-510.

Smith, C. S. (1991): The Parameter of Aspect, 1997. Kluwer Academic Press

Thomason, R. (1970): Indeterministic time and truth value gaps

Varasdi, K. (2006): On the progressive and the perfective, Disszertáció, kézirat

Vendler, Z. (1957): Verbs and Times, Philosophical Review 66 (2): 143-160.

Vlach, F. (1981): The Semantics of the Progressive in Tedeschi, P. - Zaenen, A. (szerk.): Syntax and Semantics 14. Tense and Aspect, Academic Press, New York.

Westerståhl, T. (1984): Determiners and context sets. In: Johan van Benthem és Alice ter Meulen (szerk.). Generalized Quantifiers in Natural Language, Dordrecht, Foris Publications 45-57. 